\title{
Analytical Jurisprudence and the Concept of Commercial Law
}

John Linarelli

Touro Law Center, jlinarelli@tourolaw.edu

Follow this and additional works at: https://digitalcommons.tourolaw.edu/scholarlyworks

Part of the Commercial Law Commons, Comparative and Foreign Law Commons, International Trade Law Commons, Jurisprudence Commons, and the Transnational Law Commons

\section{Recommended Citation}

114 PENN ST. L. REV. 119

This Article is brought to you for free and open access by the Faculty Scholarship at Digital Commons @ Touro Law Center. It has been accepted for inclusion in Scholarly Works by an authorized administrator of Digital Commons @ Touro Law Center. For more information, please contact Iross@tourolaw.edu. 


\section{Analytical Jurisprudence and the Concept of Commercial Law}

\section{John Linarelli*}

Commercial lawyers working across borders know that globalization has changed commercial law. To think of commercial law as only the law of states is to have an inadequate understanding of the norms governing commercial transactions. Legal comparativists have argued unpersuasively for a transnational conception of commercial law based on common content among national legal systems. Some have argued for a transnational conception of commercial law, but their grounds of justification have been unpersuasive, often grounded on claims about the common content among national legal systems. Legal positivism is a rich literature on the concept of a legal system and the validity conditions for rules in legal systems, but it has not been used to understand legal order outside or beyond the state. This article aims to use legal positivism to conceptualize a transnational commercial law order. Prevailing positivist accounts at least implicitly condition legal order on state sovereignty. This article offers a cosmopolitan conception of legal positivism, in which the state is no longer an enabling condition for law. The cosmopolitan conception provides the means by which to adequately describe a transnational commercial law order. There are limits to the conceptual analysis this article provides, one of which is that it does not purport to evaluate the justice or morality of

* Associate Dean for Academic Affairs and Professor of Law, University of La Verne College of Law. I owe a debt of gratitude to Professor Jan Dalhuisen, King's College University of London, for his encouragement throughout the years as I struggle to work out my own understanding of commercial law in ways that might be considered unusual by some. Jan and I do not agree on everything but we do agree on the important things. Thanks Jan. I presented this article at a Northeastern University School of Law colloquium on October 23, 2008 while a visiting professor at Northeastern for academic year 2008-09. I thank the colloquium participants who asked many good and tough questions, all of which helped me improve the article. In particular I thank James Hackney, the discussant in the colloquium, for his excellent comments. I also want to thank H. Randall Rubin, former Interim Dean at La Verne, for a summer research stipend in support of the preparation of this work. Finally, a special thanks to Sofia Ahmed, my research assistant at La Verne, for her excellent work. All errors are mine. 
transnational legal order. But the cosmopolitan conception of legal positivism elucidated in this article stands on its own as a way of understanding a number of transnational legal orders other than commercial law. The attractiveness of the account is that it describes law as a human social practice even when it is not solely the product of the state, so that we do not have to rely on natural law theories to understand legal rules that states do not maintain.

$[T]$ he dense thicket of rules that sustain our life together . . . includes some of the most mundane things imaginable: postal and telephone conventions, airline safety and navigation standards, the law of international trade, the practices that define the convertibility of currencies, transnational banking arrangements, weights and measures, time zones, international quarantine arrangements, and so on. Philosophers and political theorists are not much interested in these unexciting issues. We have nothing to say on currency rates, bills of sale, the maintenance of sea lanes, cell-phone standards, or the Warsaw Convention governing the liability of airlines to their passengers. We don't like commerce (because we are largely ignorant of it), and we would prefer not to have to write about it.

\section{Jeremy Waldron ${ }^{1}$}

There is no real jurisprudence of commercial law. We are presently prisoners of the conception that commercial law embodies the law merchant and that the Uniform Commercial Code merely furnishes businessmen with a clear statement of their rules.

Hal Scott ${ }^{2}$

1. Jeremy Waldron, Cosmopolitan Norms, in SEYLA BENHABIB, ANOTHER CoSMOPOLITANISM 83 (2006).

2. Hal S. Scott, The Risk Fixers, 91 HARV. L. REV. 737 (1978). 
Table of Contents

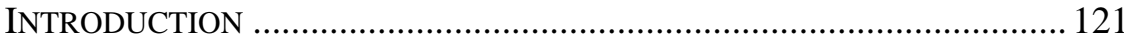

I. THE SO WHAT QUESTION ....................................................... 131

II. COMMERCIAL LAW SOURCES AND COMPETING CLAIMS

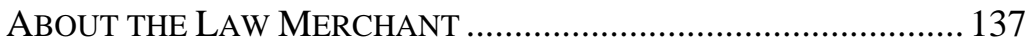

A. Domestic Commercial Legislation...................................... 141

B. Municipal Court Decisions Interpreting Domestic

Commercial Legislation................................................... 144

C. Domestic Common Law....................................................... 146

D. International Conventions .................................................... 148

E. Judicial Interpretations of Conventions ............................. 153

F. Law Merchant ................................................................ 157

1. Competing Definitions .................................................. 157

2. Legislated Law Merchant ........................................... 165

3. Interpretations of Legislated Law Merchant by Judges and Arbitrators ................................................ 177

4. Evolved Law Merchant and General Principles............. 182

III. THE CONCEPT OF COMMERCIAL LAW ...................................... 184

A. The Political Conception of Positivism and National

Commercial Law................................................................... 186

1. The Political Conception of Legal Positivism .............. 187

2. The Concept of Commercial Law in the Political Conception ................................................................. 190

B. Cosmopolitan Legal Positivism and Transnational Commercial Law................................................................ 195

1. The Cosmopolitan Conception of Legal Positivism ..... 195

2. The Concept of Commercial Law in the Cosmopolitan Conception........................................... 201

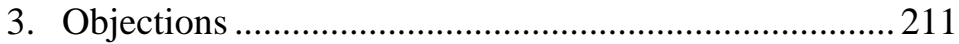

a. The Limited Domain Objection............................... 211

b. The Unity Objection................................................ 213

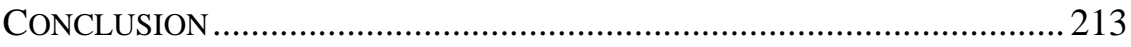

\section{INTRODUCTION}

H.L.A. Hart spent his career rethinking legal positivism around a set of claims understandable to analytical philosophers, dealing with substantial questions on the relationship between law and morality, and examining the deep structure of tort and criminal law, as well as serving, towards the end of his career, as Principal of Oxford's Brasenose 
College. $^{3}$ Never did he concern himself with a subject as mundane as commercial law. Many view Hart as the greatest legal philosopher of the twentieth century in the analytical tradition. ${ }^{4}$ To borrow without any suggestion of precision from the philosophy of science literature, Hart's contribution could be described in Thomas Kuhn's terminology as a paradigm shift in the way philosophy of law is done. ${ }^{5}$ He made the first move in analytical legal philosophy from law's authority coming from the force of the state, accounts of his predecessors Bentham and Austin, ${ }^{6}$ to a theory based on rules and social acceptance of legal obligation. His account is more suitable to understanding the relationship of citizens in contemporary democracies to their legal systems. Though their aims and accounts differed substantially, Hart's approach is as paradigmatic in the twentieth century as Rousseau's was in the eighteenth. Hart's concept of law is reminiscent of Rousseau's discrediting of force as a source of political morality, that "might does not make right."7 To put Hart in more contemporary terms, claiming that force is the source of authority for a legal system is to fail to understand the distinction between authority and force, between standing to claim and power to dictate. To Hart, being obliged to obey the command of a terrorist holding a gun to one's head differs from having an obligation to obey the law. ${ }^{8}$

3. See Nicola lacey, A Life of H.L.A. Hart: The Nightmare and the Noble DREAM 2 (2004).

4. For example, Brian Leiter, characterizing Hart as "the giant of 20th century jurisprudence,” explains that Hart brought jurisprudence "into the mainstream of Englishspeaking philosophy.” BRIAN LEITER, NATURALIZING JURISPRUDENCE: ESSAYS ON AMERICAN LEgAl REALISM AND NATURALISM IN LEGAL PHILOSOPHY 2 (2007).

5. See, e.g., Thomas S. Kuhn, The Structure of Scientific Revolutions (2nd ed. 1962).

6. See Jeremy Bentham, Of Laws in General (H.L.A. Hart ed., Athlone Press 1970); John Austin, The Province of Jurisprudence Determined (1998).

7. Rousseau said in the Social Contract:

The strongest is never strong enough to be the master forever unless he transforms his force into right and his obedience into duty. This leads to the right of the strongest, a right that is apparently taken ironically and in principle really established. But won't anyone ever explain this word to us? Force is a physical power. I do not see what morality can result from its effects. Yielding to force is an act of necessity, not of will. At most, it is an act of prudence. It what sense could it be a duty? .. . Let us agree that might does not make right, and that one is only obligated to obey legitimate powers.

JeAn-Jacques Rousseau, On the Social Contract 48-49 (Roger D. Masters ed., Judith R. Masters trans., St. Martin's Press 1978). A similar discussion is in Plato's Republic, in which Socrates and Thrasymachus debate the nature of justice. See generally 1 PLATO, Republic in Plato Complete Works (John M. Cooper ed., 1997).

8. Hart said:

The plausibility of the claim that the gunman situation displays the meaning of obligation lies in the fact that it is certainly one in which we would say that [the victim], if he obeyed, was "obliged" to hand over his money. It is, however, equally certain that we should misdescribe the situation if we said, on these 
From Hart sprung the contemporary analytical jurisprudence canon. $^{9}$ Hart argued that the practical authority of law comes from other rules, in particular, from the systemic relationship of primary rules imposing legal obligations on persons to secondary rules of recognition, change, and adjudication. ${ }^{10}$ Hart said nothing about the need for a state or sovereign to back law's authority. State law could be said to be at best a central case of the sort of institutional normative order Hart identifies. ${ }^{11}$ Hart's concern was in producing an understanding of the concept of law, but he did not claim that law is the only institutional normative order complying with his description. Hart's description of the union or primary and secondary rules describes other "non-legal" institutionalized normative systems, such as those of sporting organizations, clubs, universities, churches and business firms. ${ }^{12}$ Some scholars have claimed that the requirement of the state is in Hart's account and that it is a requirement of legal positivism generally; others have claimed to the contrary. ${ }^{13}$ Some of the critical literature is more in the nature of

facts, that [the victim] "had an obligation" or "duty" to hand over the money. So from the start it is clear that we need something else for an understanding of the idea of obligation. There is a difference . . . between the assertion that someone was obliged to do something and the assertion that he had an obligation to do it.

H.L.A. HART, THE CONCEPT OF LAW 82 (2nd ed. 1997).

9. It is not feasible here to recount that substantial literature. For surveys, see OXford HANDBOOK OF JuRisPRUdENCE AND PhilOSOPHY OF LAW (Jules Coleman, Scott J. Shapiro, \& Kenneth E. Himma eds. 2002); A Companion to Philosophy OF LAW AND Legal Theory (Dennis Patterson ed. 1999); Leslie Green, Legal Positivism, STANFord ENCYCLOPEDIA OF PHILOSOPHY, http://plato.stanford.edu/entries/legal-positivism/ (last visited June 20, 2009).

10. Philosophers call the kind of authority a legal rule or moral principle has over us practical authority. Practical authority issues a reason for action. It is action guiding. Legal philosophy asks questions about why the law is binding on us. Practical authority is to be distinguished from theoretical authority, which issues reasons to believe. The concept of practical authority does not require any special citation in a philosophical work. To see the concept in action in a recent influential work of moral philosophy, see Stephen Darwall, The Second Person Standpoint: Morality, Respect, and ACCOUNTABILITY 11 (Cambridge MA: Harvard University Press 2006). The question of the practical authority of law has been one of the central questions of legal positivism. How are we to understand the claim to obedience that law makes on persons? See Leslie Green, Legal Obligation and Authority, Stanford Encyclopedia of Philosophy, http://plato.stanford.edu/entries/legal-obligation/\#2 (last visited June 20, 2009).

11. NeIl MacCormick, H.L.A. HaRT 34, 136 (Stanford: Stanford University Press 2007).

12. Id., at 21; JOSEPH RAZ, PRACTICAL REASON AND NORMS 123-48 (1990).

13. See, e.g., A. Clair Cutler, Private Power and Global Authority: Transnational Merchant LAW IN THE Global Economy 7, 60-67, 74-76 (2003) (legal positivism under stress); Ralf Michaels \& Nils Jansen, Private Law Beyond the State?: Europeanization, Globalization, Privatization, 54 AM. J. CoMP. L. 527 (2006) (limited discussion of why there is "no good reason" why a rule of recognition or other grundnorm requires a state). Gunther Teubner's work in legal pluralism and law as an 
assertion than justification. But the critics are on to something that seems to threaten the core of legal positivism. What else, in a positivist account of the law, would posit law for the norm users in a legal system other than the state and its government? It seems a reasonable conclusion to draw that the existence of a state is an enabling condition for law in the positivist account. ${ }^{14}$ Joseph Raz, perhaps the most influential of the Oxford analytical philosophers after Hart, seems to at least implicitly agree in his work, but he also, like Hart, does not explicitly specify the need for a state. ${ }^{15}$ It could just be that the requirement of the state is such an obvious background condition for legal positivism that it does not need to be articulated as an express condition. In this article I give legal positivism the benefit of the doubt to see where it leads.

While analytical jurisprudence developed into an intricate set of claims in its own literature, another literature, grounded in commercial law and comparative law, made its way through journals in this country and globally, on the nature of commercial law and whether non-state actors have a role in the production of a contemporary law merchant. ${ }^{16}$ This is the literature on the notion of transnational commercial law. It contains substantial and seemingly interminable discussions between commercial law nationalists and commercial law cosmopolitans. Lawyers, judges, famous international commercial arbitrators, and legal scholars have been going back and forth for decades on whether the law merchant exists and if so, what it is comprised of, what kind of respect it deserves, and how should it come into play in commercial disputes. ${ }^{17}$

autopoietic system states generalizations about how the law merchant meets Hart's conditions for a legal system, but his work is not analytical philosophy and might be seen as a critique of Hart's work as too nationalist. Gunther Teubner, "Global Bukowina:" Legal Pluralism in the World Society, in Global LAw Without a State 3, 8 (Gunther Teubner ed. 1997); Gunther Teubner, Breaking Frames: The Global Interplay of Legal and Social Systems, 45 AM. J. Comp. L. 149 (1997). William Twining can be read as broadly sympathetic to Hart, but he is a legal pluralist and skeptical about legal positivism. See William Twining, Globalisation AND LEgal TheORY (2000).

14. I borrow the enabling condition concept from Thomas Nagel's Storrs Lecture at Yale Law School. Thomas Nagel, The Problem of Global Justice, 33 PHIL. \& PuB. AfFAIRS 113 (2005). Nagel uses the concept to identify what he calls a political conception of justice, in which states, governments and sovereignty are enabling conditions for justice. He contrasts the political conception of justice with the cosmopolitan conception of justice.

15. To require a state for a legal system might contradict the purported political neutrality of legal positivism. Why analytical jurisprudence resists this concession is puzzling. Justice theorists have not. See generally JoHn RAWLS, LAW OF PEOPLES (2001).

16. Rather than try to cite that voluminous literature here, I note for the reader that it is cited throughout the article.

17. For discussions of the controversial aspects of claims that a modern law merchant exists, see infra notes 145-287 and accompanying text. Yves Dezalay \& 
The substantial disagreement over this question has no end in sight. ${ }^{18}$ Lord Mustill, a British Law Lord and an accomplished international commercial arbitrator, and also outspoken critic of the idea that a law merchant exists, has asked:

What is the jurisprudential basis of the lex? It is remarkable that given the volume of academic writing on the topic - a volume which considerably exceeds that of the [arbitral] awards which purport to put the doctrine into practice-there is even now no consensus on the intellectual basis of the doctrine. Is the lex a law, properly so called, or is it a body of rules which the parties choose (expressly or impliedly) to apply to their individual contract? If it is a law, from where does it draw its normative force? ${ }^{19}$

To my knowledge, no one has answered Lord Mustill's question about the jurisprudential basis or normative force of the law merchant.

The aim of this article is to assess whether analytical jurisprudence can provide an adequate descriptive account of a transnational conception of commercial law, which includes the law merchant as well as state-based sources of law. This is the first account of the analytical jurisprudence of commercial law. ${ }^{20}$ To my knowledge, no one has used analytical jurisprudence to develop insights about either commercial law

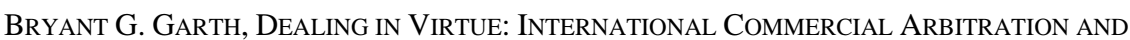
the Construction of A Transnational Legal Order 39-48 (1996); Jan H. Dalhuisen, Legal Orders and Their Manifestation: The Operation of the International Commercial and Financial Legal Order and its Lex Mercatoria, 24 BERKELEY J. INTL L. 129 (2006); Gunther Teubner, Global Bukowina, supra note 13.

18. Ralf Michaels explains:

For some time, positions on the question of whether an anational law merchant existed or exists were matters of faith rather than academic rigor, and some participants in the debate seemed driven more by the wish to defend their own fields than by a disinterested search for adequate theories. Scholars and especially practitioners in the debate seemed driven more by the wish to defend their own fields than by a disinterested search for adequate theories. Scholars and especially practitioners in commercial and arbitration law promoted lex mercatoria not least because their fields seemed to benefit from it. Scholars of conflict of laws, by contrast, abhorred the idea of a non-state law demanding recognition, not least because they feared for central tenets of their field. Empirical issues mattered surprisingly little in this debate.

See Ralf Michaels, The True Lex Mercatoria: Law Beyond the State, 14 Indiana J. GLOBAL LEGAL STUD. 447, 448-49 (2007).

19. Rt. Hon. Lord Justice Michael Mustill, Contemporary Problems in International Commercial Arbitration: A Response, 17 INT'L Bus. LAW. 161-63 (1989); see also Rt. Hon. Lord Justice Michael Mustill, The New Lex Mercatoria: The First Twenty-Five Years, in LIBER AMERICORUM FOR THE RT. HON. LORD WiLBERFORCE (Maarten Bos \& Ian Brownlie eds. 1987).

20. A limited attempt to identify principles underlying commercial law can be found in Roy Goode, The Codification of Commercial Law, 14 MonASH. U. L. REv. 135 (1988), a very different project from mine. 
or the law merchant. ${ }^{21}$ There has been limited brief discussion of Hart's work in the literature, but no philosophical account centering on it. ${ }^{22}$

21. Commercial law involves both contract and property; areas such as sales are based in contract but are means to transfer property and areas such as secured credit and negotiable instruments are based in property but are created by contract. A significant literature provides philosophical accounts of contract and property. These do not extend to offer a satisfactory philosophy of commercial law. Private law categories of contract, property, tort, and restitution serve as a base for many commercial law concepts, just as equity and fiduciary duty does for corporations, but the fields can be conceptualized as entirely distinct, and have been so conceptualized in Europe. Failing to make the distinctions often leads to errors, as, for example, in thinking of commercial law as an extension of contract law, and not understanding that a substantial part of commercial law is about personal property. For a survey on the philosophy of contract law, see Jody S. Kraus, Philosophy of Contract Law, in THE OXFORD HANDBOOK OF JURISPRUDENCE AND Philosophy OF LAW, supra note 9, at 687. Kraus contends: "As in private law scholarship generally, economic analysis is the dominant paradigm in contemporary contracts scholarship. But alongside the vast body of economic contracts scholarship produced over the last thirty years, a core body of philosophical contracts scholarship has steadily developed in relative obscurity." Id. at 687. For a selective sample of contemporary literature see, e.g., Eric A. Posner, Contract Theory, in THE BLACKWELL Guide to the Philosophy of LAW AND Legal THEORY 138 (Martin Golding \& William A. Edmundson eds., 2005); StePhen A. SMith, CONTRACT TheOry (2004); The THEORY of Contract Law (Peter Benson ed., 2001); Larry A. DiMatteo, Equitable Law of Contracts: STANDARDS AND PRinciples (2001); Michael TREBILCOCK, THE LiMits of FreEdom of Contract (1993); JAMES GordLEy, The Philosophical Origins of Modern Contract Doctrine (1991); Charles Fried, Contract as Promise: A Theory of Contractual Obligation (1982); Larry A. DiMatteo, The History of Natural Law Theory: Transforming Embedded Influences into a Fuller Understanding of Modern Contract Law, 60 U. PITT. L. ReV. 839 (1998); Peter Benson, Abstract Right and the Possibility of a Nondistributive Conception of Contract: Hegel and Contemporary Contract Theory, 10 CARdozo L. REV. 1077 (1989); Randy E. Barnett, A Consent Theory of Contract, 86 Colum. L. REv. 269 (1986). Philosophical accounts of property have mainly to do with the justification of private property. For a survey, see Peter Benson, Philosophy of Property Law, in THE OXFORD HANDBOOK OF JURISPRUDENCE AND PHILOSOPHY OF LAW, supra note 9, at 752; see also NEW ESSAYS IN THE LEGAL AND Political Theory of Property (Stephen R. Munzer ed. 2001); Jeremy Waldron, The Right to Private Property (1991); Stephen R. Munzer, A Theory of Property (1990).

22. For mentions of Hart in connection with the law merchant, see Michaels \& Jensen, supra note 13; Stephen Perry, Hart on Social Rules and the Foundations of Law: Liberating the Internal Point of View, 75 FordHAM L. REv. 1171, 1184 (2006). To Perry, the "rules of the old law merchant," by which I assume he means the medieval law merchant, were "a borderline case of a legal system" in which "all the primary rules identified as valid by a rule of recognition might consist of preexisting customary rules that hold among ... some segment of the population.” He notes that the law merchant served as both legal and social rules among merchants. His discussion of the law merchant is incidental; Joanna Jemielniak, Legitimization Arguments in the Lex Mercatoria Cases, 18 INT'L J. FOR THE SEMIOTICS OF LAW 175 (2005); Robert Cooter, Decentralized Law for a Complex Economy: The Structural Approach to Adjudicating the New Law Merchant, 144 U. PA. L. REV. 1643, 1654 (1996) for an economic take on Hart's concept of a legal system; Abdul F.M. Maniruzzaman, The Lex Mercatoria and International Contracts: A Challenge for International Commercial Arbitration?, 14 АM. U. INT'L L. REV. 657, 699 (1998), in which the author says that "[i]t is beyond the scope of this present paper to examine the status of the lex mercatoria as a legal order or legal 
Commercial lawyers and analytical legal philosophers are very different sorts, working in divergent traditions. The traditional work of the commercial lawyer has been in doctrinal analysis. Commercial law doctrinalists do important work, which needs to be respected, though it may have influenced lawyers to focus on an incomplete set of sources for commercial law, making them too reliant on national law and national projects of unification as the sole or main sources of commercial law. Newer commercial law scholarship is based predominantly in law and economics, and is increasingly empirical. ${ }^{23}$ The legal pluralism literature offers substantial insights on the law merchant. ${ }^{24}$ Apart from the legal pluralism literature, which can be classified as law and society scholarship, the law and society movement has been influential on the margins of commercial law scholarship, ${ }^{25}$ and some of the economic research, particularly that which relies on qualitative data and is in the new institutional economics tradition, shares affinities with sociological methods. $^{26}$

system in the light of contemporary analytical theories of legal systems propounded by such noted theorists such as Kelsen, Hart and Dworkin," but then concludes that "[f]or our present purpose, it will suffice to say that lex mercatoria, in the Austinian positivistic perspective, does not entirely conform to some important features of a legal system, namely the characteristics of institutionalization and coerciveness, though it qualifies for the normative character." (footnotes omitted). Why the author bothers with Austin, whose philosophy is only of historical interest, he does not say; Raj Bhala, Applying Equilibrium Theory and the FICAS Model: A Case Study of Capital Adequacy and Currency Trading, 41 ST. LouIS L. J. 125, 202 (1996). Bhala concludes that Hart is to be distinguished from Austin because he makes "room for law to be created without formal enactment of a sovereign, and many laws confer power on private parties to engage in self-regulation." Bhala refers to the law merchant as an example. His aim is not philosophical justification, so he offers none. As explained supra note 13 Teubner offers generalizations about how the law merchant meets Hart's conditions for a legal system, but his work is not analytical philosophy and might be seen as a critique of Hart's work as too nationalist. Teubner, Global Bukowina, supra note 13; Teubner, Breaking Frames, supra note 13.

23. See, e.g., Bernstein, infra note 184 and the work of Ronald Mann as perhaps early pioneering work in the new wave of empirical commercial law scholarship working broadly within the law and economics approach. http://www.law.columbia.edu/fac/ Ronald_Mann (last visited December 24, 2008).

24. See Paul Schiff Berman, Global Legal Pluralism, 80 S. CaL. L. Rev. 1155 (2007) (summarizing the legal pluralism literature, providing ways of addressing conflicts among norms, and describing legal practices that manage legal pluralism); Teubner, Global Bukowina, supra note 13; Teubner, Breaking Frames, supra note 13; Bonaventura de Sousa Santos, Towards a New Legal Common Sense (2nd ed. 2003); Brian Z. TAMANAHA, A GENERAL JuRISPRUdENCE OF LAW AND SOCEITY 125-27 (2001); Michaels \& Jensen, supra note 13; Michaels, supra note 18.

25. But see Garth \& Dezalay, supra note 17, which suggests an important role for law and society methods in commercial law scholarship, at least for transnational conceptions of commercial law.

26. See supra note 23. 
Legal scholars have relinquished the task of "jurisprudential" thought about commercial law to law and economics. A significant addition to the literature on commercial law theory in the past five or so years bears the title, The Jurisprudential Foundations of Corporate and Commercial Law. ${ }^{27}$ It contains an excellent set of primarily law and economics papers, but the use of the words "jurisprudential foundations" is misleading, unless we are willing to concede that economics is almost all there is to commercial law. ${ }^{28}$ One of the major gaps in the philosophy of law canon is the near total absence of a philosophical account for commercial law. This article aims to fill that gap.

I should be clear at the outset that I am not convinced that legal positivism can do the job. This article is partly an exercise in understanding the limits of prevailing accounts in analytical philosophy and how they may fail to offer adequate descriptions of law in globalizing contexts. Putting the two subjects of transnational commercial law and legal positivism together creates tension. Though positivism claims not to rely on the political concepts of state and sovereignty, I test to see how far I can use it to conceptualize an area of law that has globalized to a pervasive degree. Positivism claims to be descriptive but risks no longer being adequate if it cannot describe the spread of norms outside of state control and their relationship to norms within state control. The field of inquiry that may better perform that task is legal pluralism. ${ }^{29}$ I may refer tangentially to some descriptive claims by legal pluralists, but this article is not scholarship in legal pluralism.

Part I is a brief introduction to what legal philosophers do when they do conceptual analysis. This article is pitched not only to legal philosophers, but also to commercial lawyers and to scholars working on commercial law and the law merchant in other disciplines. Part I is needed because there has been some expression of skepticism of the relevance of philosophy and conceptual analysis to the law. Obviously, Part I deals with substantial questions with roots deep within the discipline of philosophy, and it can offer only a sketch of these questions and their answers.

Part II identifies the plausible sources of commercial law. These sources provide the primary rules in Hart's legal positivism. In providing that identification, we must identify the law merchant as a

27. The Jurisprudential Foundations of Corporate and Commercial LaW (Jody S. Kraus \& Steven D. Walt eds.2007).

28. The first sentence of the Kraus and Walt book states: "Efficiency is the dominant theoretical paradigm in contemporary corporate and commercial law scholarship." Id. at 1.

29. See supra notes 13,24 and accompanying text. 
possible source of commercial law. Part II examines competing claims about the law merchant. It is needed to stipulate the potential scope of the question of how we are to understand what commercial law is. Lawyers and legal scholars have spilled quite a bit of ink on a number of issues about the law merchant. These include whether there is anything to commercial law other than official state law; if the law merchant does exist, then what falls within its scope; whether the law merchant has a connection to the medieval lex mercatoria, whether the law merchant should govern as norms that private actors prefer to govern their private relationships and in what circumstances; whether courts have incorporated the law merchant into the common law; whether the law merchant should be incorporated into state law, and so on. Part II introduces these and other claims. A point that comes out of Part II is that prevailing accounts of the law merchant proponents, who are the leading proponents to date of a transnational commercial law order, cannot succeed on their own terms in showing that the law merchant is a valid source of law in a transnational commercial law order. The law merchant proponents confuse analogous content of legal norms with the validity of those norms in a legal system.

Part III elucidates the central claims of my account. In Part III I ask, using the teachings of legal positivism, whether a system of transnational commercial law exists. ${ }^{30}$ In trying to answer that question, I examine the role of the plausible commercial law sources identified in Part II. Part III is an attempt to elucidate a transnational commercial law order. To do this, Part III first identifies two conceptions of legal positivism, one a political conception in which states are supreme, and the other a cosmopolitan conception in which states coordinate with

30. I prefer to use "transnational" rather than "international" because the latter carries with it the notion of the law governing states. In 1956, Philip Jessup made prominent the term "transnational law," which he defined as "all law which regulates actions or events that transcend national frontiers.” Philip C. Jessup, Transnational LAW 2 (1956), quoted in Gralf-Peter Calliess, The Making of Transnational Contract Law, 14 Indiana J. Global Legal Stud. 469 (2008). A distinction is to be made, however, between the concept of transnational law and the concept of the law merchant. Transnational law includes all law, regardless of source, regulating conduct that crosses national borders. I have tried in Part II to clarify the concept of the law merchant to comprise only a part of transnational law, as commercial law that is not produced by states. The law merchant is thus only one source of transnational law. See Norbert Horn, The Use of Transnational Law in the Contract Law of International Trade and Finance, in The Practice of Transnational Law 67 (Klaus Peter Berger ed. 2001) (suggesting similar definitions). For an example of the interchangeable use of the terms "transnational commercial law" and "new law merchant," see Christopher R. Drahozal, Contracting Out of National Law: An Empirical Look at the New Law Merchant, 80 Notre DAME L. ReV. 523 (2005). 
other institutional normative orders. ${ }^{31}$ My account of a cosmopolitan conception of legal positivism tries to dissolve the notion of the state as an implicit enabling condition for the law. A cosmopolitan conception of legal positivism, one which removes the state as an enabling condition ${ }^{32}$ for a legal system, requires that any candidate for the designation of a legal system meet five conditions: (1) acceptance by the participants in the legal system, the norm users, ${ }^{33}$ of the rules of the order as valid, binding, and authoritative; (2) systemic qualities of normative consequence within the putative legal system that make the normative order the system represents intelligible or comprehensible to the participants; (3) secondary rules and secondary rule officials, though they can be distributed across different state and non-state hierarchies; (4) shared agency between secondary rule officials demonstrating sufficient mutual responsiveness and joint commitment for a legal system; and (5) primary rules dealing with issues that legal systems usually deal with, such as property, contract, and dispute resolution.

Part III elucidates a transnational commercial legal order around these conditions. I think reasonable arguments can be made that these conditions are met for commercial law, but that some considerable objections become evident. The first condition has to do with acceptance of a transnational legal order by merchants or professionals. Merchants certainly do accept the rules produced by state and non-state institutions, but whether they accept these rules as comprising a transnational system of commercial law is doubtful. The second condition is possibly met because there do seem to be some systemic connections in the production of state and non-state rules to make commercial law a sensible system for the regulation of commercial activity. Those systemic connections are in the complementary ways in which state and non-state institutions produce complementary rules that one set of institutions does not make, and the other fills the gaps. The third condition seems to be met. Secondary rules and secondary rule officials exist in abundance, in both state and non-state institutions to produce a variety of important commercial law rules. As to the fourth condition, Michael Bratman's descriptions of shared agency, in particular his notion of a shared intentional activity, ${ }^{34}$ help answer whether the fourth condition informs us of a transnational commercial law order. There seems to be some

31. I adapt these two conceptions of legal positivism from Nagel's description of two competing conceptions of justice, one political and the other cosmopolitan. Nagel, supra note 14.

32. Nagel uses similar terminology for different purposes. Nagel, supra note 14.

33. The "norm users" terminology is from NeIL MACCORMICK, INSTITUTIONS OF LAW: AN ESSAY IN LEGAL THEORY 20-22 (2007).

34. See infra notes 329-36 and accompanying text. 
mutual responsiveness and joint commitment of secondary rule officials, though, I conclude, some judges and other secondary rule officials tend to not remain steadfast nationalists. The fifth condition is met because the primary rules of commercial law deal with social practices that legal systems regulate.

As Part III explains, in addition to the problems a transnational conception of a commercial legal order has in meeting all of the five conditions, the case is weakened by at least two objections. One objection, the limited domain objection, is that legal systems have not been understood as covering a limited sphere of social activity, in particular here, commercial life. Surely no legal system is comprehensive in the sense of regulating all human action. Legal systems do not (or should not?) regulate action relating to what liberals might call the private side of morality, for example. ${ }^{35}$ But the limitation of a legal system to that of commercial law may go too far; it leaves untouched by the law vast areas of human action that legal systems almost always regulate. To limit scope to just commercial law may be too implausible. A second objection, the unity objection, is that it seems more plausible to claim that transnational commercial law is better understood as a distribution of multiple normative communities across state borders that are independent but which coordinate, but to claim that they form a unified whole may go too far.

In the end, while we may encounter obstacles in conceptualizing a unified system of transnational commercial law, conceptual analysis is about getting clear on our concepts, and in that process of clarification we come to improve our understanding of the ways commercial law operates on a transnational scale.

\section{THE SO WHAT QUESTION}

Some legal scholars have raised worries about whether philosophy can deliver the goods. The main worry is whether philosophy can be prescriptive. $^{36}$ Law professors, particularly in the U.S., want to know

35. John Rawls makes similar arguments with his notion of public reason. JoHN RAWLS, Political LiBERALiSM (1995).

36. Philosophers have no difficulties with lack of prescription. Kwame Anthony Appiah can get away with saying in the preface of his influential book on the ethics of identity:

My last and most forceful disclaimer ... is addressed to those who are looking

for practical guidance, for specific recommendations about precisely what laws and institutions will best heal our social and political ills. Alas, I am a poor physician: I'm interested in diagnosis-in etiology and nosology-but not in cures. If an agenda, a set of action items is what you're after, my one bit of practical advice is that you look elsewhere.

KWAME ANTHONy ApPIAH, The Ethics of IDENTITY xvii (2005). 
how a particular theory or approach tells us about whether the law is satisfactory, good, right, should be changed, and so on. Philosophers would likely call this task social critique, and some might have the opposite worry of the legal scholar-whether philosophers should engage in it. ${ }^{37}$ Brian Bix has expressed frustration with his colleagues' obsession with public policy prescriptions:

It is important to note the inclination, quite strong among American legal academics-less so among theorists from continental Europe ... to want always to know the normative ("bottom line") consequences for any theory they consider. They find analytical legal philosophy ... deeply frustrating because of its refusal to offer prescriptions based on its theoretical claims.

The response one often finds when presenting an analytical legal philosophy paper is something along the lines of, "If your theory has no consequences for what we do, for how we practice law, what good is it, and what is the point of doing such work?” In general, I have little sympathy for the normative fixation of American legal scholars. Of course, critique and prescription are extremely important, but there is ample room for knowledge for its own sake-in legal history and the history of ideas, for example; and in metaphysics—even if no immediate pragmatic use of that knowledge is forthcoming. ${ }^{38}$

Bix uses the word "normative" to distinguish between normative and conceptual analysis of the law. ${ }^{39}$ Normative analysis is analysis to understand what law's content is or should be. When philosophers do

37. For a summary of the views of several moral philosophers, see T.M. Scanlon, The Aims and Authority of Moral Theory, 12 OxfORD J. LEGAL STUD. 1 (1992).

38. Brian Bix, Joseph Raz and Conceptual Analysis, APA NEwSL. ON PHIL. AND L. 1, $3(2007)$.

39. I bracket the claim that the normative can be separated from the conceptual or the descriptive. The fact-value distinction has been the subject of a considerable philosophical literature. Hannah Pitkin, for example, provides a Wittgensteinian take on the problems with the distinction. HANNAH F. PITKIN, WiTTGENSTEIN AND JUSTICE 177178, 219-231 (Berkeley: University of California Press 1993). Any time one examines rules, or reasons for action, the untenability of the distinction is particularly problematic. A rule is a description of how one ought to do something. See id. at 228. Another way to access the critique of the fact-value distinction is through hermeneutics. For general discussions of these issues, see Alexander Rosenberg, Philosophy of Social Science (2nd ed. 1995); Martin Hollis, The Philosophy of Social Science: An Introduction (1994). So, for example, arguments that judges should "say what the law is rather than what it should be" are hopelessly confused, because the very pronouncement of what "is" pronounces what "ought to be." The problems with inserting the fact-value distinction into the judicial process or any sort of adjudicatory process are many. Hart and other legal positivists, going back to Bentham, accept the distinction between what the law is and what it ought to be. H.L.A. Hart, Positivism and the Separation of Law and Morals, 71 HARV. L. REv. 593 (1958). It is beyond the scope of this article to take on these substantial questions. 
normative jurisprudence, they inquire whether the law's content meets or should meet some normative criterion fixed by theories of justice, deontological ethics, or consequentialist theories such as utilitarianism. An economic theorist claiming that the law should be efficient is doing normative economics, usually normative welfare economics. When philosophers do analytical jurisprudence, they are not doing normative analysis, but conceptual analysis. When philosophers do conceptual analysis, however, they look for law's normativity, but in a different way. They want to describe how that normativity works in the legal system. They look for it in the existence of conditions that makes law what it is, and not in its content. So, philosophers look to why law makes a claim of obedience on persons, not on what the content of that claim of obedience is or should be.

What is conceptual analysis? Ludwig Wittgenstein, one of the most influential figures in twentieth century analytical philosophy, said that philosophy is an "activity of clarification." 40 According to Joseph Raz, "conceptual analysis concerns the logical features of concepts." ${ }^{41}$ To combine Wittgenstein's and Raz's insights, we use conceptual analysis to get clear on the meaning of concepts. ${ }^{42}$ The idea is that we should strive to understand the meaning of, say, legal obligation, right, duty, justice, and so on to the humans who actually use the concepts in their everyday speaking of a public language. But as Raz explains, we must not be "slaves of words." 43 Language reveals beliefs and attitudes. ${ }^{44}$ In conceptual analysis, we want to get to the propositional content of those beliefs and attitudes in the way the speakers of a language use the language. Analytical philosophy, at least in the way it is done here, is not concerned with the discovery of external entities or properties independent of human existence. "Obligation," legal, moral or otherwise, is not some metaphysically real thing, furniture of the universe. $^{45}$ It is what it means to us, and we access what it means to us

40. P.M.S. HACKER, INSIGHT AND ILLUSION 151 (Rev. ed. 1986); MARIE McGinN, WitTGENSTEIN AND THE PHilosophicAl INVESTigations 12-16 (1997).

41. RAZ, PRACTICAL ReASON AND NoRMS, supra note 12, at 10.

42. The suggestion here is not that Wittgenstein and Raz agree on the task of philosophy. Wittgentein raised doubts about whether conceptual analysis was worth doing. Brian Leiter, Introduction in The Future FOR PhILOsophy 3 (Brian Leiter ed., 2003). Raz, on the other hand, is one of the most preeminent of analytical legal philosophers who use conceptual analysis.

43. Joseph Raz, The Authority of Law: Essays on LaW and Morality 41 (1979).

44. Brian Leiter, Legal Realism, Hard Positivism, and the Limits of Conceptual Analysis, in BRIAN LEITER, NATURALIZING JURISPRUDENCE: EsSAYS ON AMERICAN LEGAL REALISM AND NATURALISM IN LEgal PHILOSOPHY 123-25 (2007).

45. The phrase "furniture of the universe" is often attributed to J.L MACKIE, ETHICS: INVENTING RIGHT AND WRONG (1990), though it does not appear in the book. It is 
through the analysis of concepts we use in ordinary speech. To continue with the example of the concept of obligation, Hart used conceptual analysis to distinguish between being obliged and having an obligation. ${ }^{46}$

I want to go back to what I will call Bix's point, because I have to convince the skeptical legal scholar that this article is worth reading. Bix's point centers on the "so what" question. The question lawyers are prone to ask about philosophy of law is "so what." So what does philosophy tell us about commercial law that we do not already know? What is the point of having a philosophy of commercial law? After all, isn't commercial law all about economics, since it concerns interactions that are inherently economic in character? Philosophy can tell us a great deal about commercial law.

If some legal scholars lose patience with philosophical analysis, then it is up to those of us who do it to show why our work deserves respect, though I concede the point that in the interdisciplinary world in which American law professors are situated, that is difficult. Those who work in legal philosophy are in a good position to use their skills to engage in wide reflective equilibrium and take into account all considered judgments, economic, doctrinal, ethical, critical, and so on, in reaching conclusions about the law. ${ }^{47}$

commonly used to refer to approaches to practical philosophy in which concepts are understood as metaphysically real.

46. Hart, The Concept of LAW, supra note 8, at 82-84; William LuCy, Philosophy OF PRIVATE LAW 4 (2007).

47. Legal philosophers working in the Rawlsian tradition talk of "working out" claims and justifications using what Rawls described as reflective equilibrium. Rawls distinguished between narrow and wide reflective equilibrium. When we engage in narrow reflective equilibrium, we work back and forth between moral judgments about particular situations and general reasons and principles. We attempt to link moral judgments to the general reasons and principles. So, two considered moral (legal, political) judgments might be that "people have a right to avoid a contract procured through fraud" and "banks should not honor checks they know to have been altered through forgery." These particular judgments are linked to general principles like "all persons have the right to be treated fairly and honestly by other persons," with the concepts of fairness and honesty having working out understandings, which in turn link to more abstract principles such as "the state should secure for its citizens all purpose means to achieve whatever good life they happen to choose." When we engage in wide reflective equilibrium, we probe and question our general reasons and principles, and do not accept them as givens. In wide reflective equilibrium, we "widen the circle of justificatory beliefs.” NORMAn DANiEls, Justice AND JustificATION: Reflective EQUILIBRIUM IN THEORY AND PRACTICE 1 (1996). It is "the process of bringing to bear the broadest evidence and critical scrutiny one can, drawing on all the different moral and non-moral beliefs and theories that arguably are relevant to our selection of principles or adherence to our moral judgments." Id. at 1-2. "The key idea underlying the method of [wide] reflective equilibrium is that we 'test' various parts of our system of moral beliefs against other beliefs we hold, seeking coherence among the widest set of moral and nonmoral beliefs by revising and refining them at all levels." Id. In wide reflective equilibrium we can consider not only moral theories but social science theories and 
Bix is right: prescription need not always be the end product of all inquiries about the law. For example, an approach to doing doctrinal analysis is to defer to the policy choices of courts, legislatures, and other official sources, and to seek to clarify the law, while carefully avoiding any effort to prescribe what is beyond what is intended by official sources to be the meaning of the law in question. ${ }^{48}$ The aim of empirical studies of the law is often ground clearing and clarifying, designed to reveal how our folk intuitions about the effects of the law or about social problems are wrong. More generally, conceptual analysis shares with science the aim of discovery of truth. Some important empirical work in commercial law fulfills precisely such descriptive or truth-seeking purpose, though prescription inevitably follows from description, because the description has found something wrong. If a bankruptcy scholar concludes that the Bankruptcy Code is not doing what it is supposed to be doing, with the "supposed to be doing" previously decided under some pre-existing normative framework, then a proposal for changing the law inexorably follows. ${ }^{49}$

Conceptual analysis need not, as a matter of necessity, only produce knowledge for its own sake and lack prescriptive significance in all cases. It can be prescriptive, in the sense that it requires us to consider new perspectives, new ways of seeing what has always been there and always been familiar and obvious. Wittgenstein tells us that philosophy provides us with "observations which no one has doubted, but which have escaped remark only because they are always before our eyes." So, it has always been an obvious feature of commercial life that norms

empirical findings. Id. at 6 . We thus can use economics. So, in our examples above, we might want to determine whether our considered moral judgments about fraud and forgery cohere with efficiency, least cost avoider arguments, and so on.

48. If normativity is as pervasive as I suggest, neutrality as to the meaning of the law seems implausible. But consider the discussion in a research colloquium at the University of East Anglia Law School some years ago. The colloquium was on Jill Morgan's article on whether the UK Human Rights Act applies to the registered social landlords in the UK. Registered social landlords are quasi-public entities that are managing the increasingly privatized public housing stock in the UK. Jill Morgan, The Alchemists' Search for the Philosophers' Stone: The Status of Registered Social Landlords under the Human Rights Act, 66 MoD. L. REV. 700 (2003). In the workshop, I asked whether the Act should apply to these public authorities. The answer I got back expressed some doubt about whether such questions are within the scope of legal analysis. To an American legal academic, the answer might seem non-responsive. The answer, however, is acceptable to many legal scholars outside of the United States, who engage in the sort of rigorous doctrinal analysis underlying Morgan's answer. This is not meant as a criticism of that approach.

49. See, e.g., Elizabeth Warren \& Amelia Warren Tyagi, The Two-Income Trap (2004); TERESA A. SulLivan, Elizabeth WARREN \& JAy LAWRENCE WESTBRoOK, The Fragile Middle Class: Americans In DebT (2000).

50. LudWig Wittgenstein, Philosophical InVestigations ף 415 (G.E.M. Anscombe trans., 3d ed. 2001). 
come from outside of official, nation-state dominated legal sources, but it has been difficult for lawyers to recognize the full implications of such norms and how they might work in commercial dispute resolution. Conceptual analysis might shed light and lead to prescription. It has the potential to offer important insights about commercial law, and these insights have the potential to change the way we "do" commercial law as an activity in the world. A positivist account of a domestic legal order that no one disputes exists at a mature level of development might offer few new insights, but when we use analytical jurisprudence to discover whether a legal order exists in the first place, from sources we always knew existed but which present themselves to us in a new light once we apply philosophical techniques to them, then we might learn a great deal, enough so that prescriptions may indeed follow inevitably from our new insights. $^{51}$ When we elucidate the concept of commercial law in a transnational context, we have the potential to make a significant contribution to the discussion of whether the law merchant is law, a question that has puzzled lawyers across the globe for a long time. Gunther Teubner, who has written some of the most theoretically rich and sophisticated work on the status of the law merchant as law, explains that "[t]he debate on lex mercatoria is one of the rare cases in which practical legal decision-making becomes directly dependent on legal theory."52 Our new insights could change the way we understand commercial law.

That this chapter provides a conceptual analysis of the concept of commercial law does not mean that no empirical propositions enter into the analysis. What is to follow has elements of what has become known as applied philosophy. The work that is to be done might eventually become what is known as social theory. ${ }^{53}$ To get clear on what commercial law is, we shall have to understand institutions that produce commercial law. To understand these institutions we need to dig deep into what philosophers call social practices. When we seek to describe

51. A potentially fruitful line of inquiry would be to use analytical jurisprudence to promote understanding of legal orders in developing countries. This line of inquiry has not been pursued, likely because legal philosophers and law and development scholars work in divergent fields of legal scholarship.

52. Teubner, Global Bukowina, supra note 13, at 8; see also Michaels, The True Lex Mercatoria, supra note 18, at 449-52 (discussing Teubner's theory). Teubner uses systems theory and autopoiesis to understand the lex mercatoria and the globalization of law generally. See Gunther Teubner, LAW As An Autopoietic System (WileyBlackwell 1993).

53. The sociologist Anthony Giddens characterizes social theory as an umbrella: "It is a body of theory shared in common by all the disciplines concerned with the behaviour of human beings. It concerns not only sociology, therefore, but anthropology, economics, politics, human geography, psychology-the whole range of the social sciences.” ANTHONY Giddens, PROFILES AND CRITIQUES In SOCIAL THEORY 5 (1982). 
social practices, we cannot deny that we are uncovering facts, which may then be classified as empirical work, though it is nothing more than what lawyers might do when they describe and evaluate legal institutions. When we inquire of the social practices of our putative legal orders, we want to understand what commercial law is; is it only the declarations of government officials who work for nation-states, or is it something else or more?

\section{COMMERCIAL LAW SOURCES AND COMPETING ClAimS ABOUT THE LAW MERCHANT}

This part identifies, in a Hartian conception of legal rules, the primary rules of commercial law. At least a plausible claim can be made that to limit oneself to considering only the municipal law of nationstates, with extensions of that law based on treaties and conventions entered into by states, as the only possible sources of commercial law, can lead to a serious misunderstanding of the nature of commercial law. I make the case here for identification only of plausible sources. I do not want to beg the question of what commercial law is, as that question would have to be conceptually justified, which is the subject of Part III.

What would be the reasons for a municipal law restriction? It would seem to be in the nature of an arbitrary stipulation, unrelated to the law and its structure, but instead based on historical artifact, politics, and nationalism. States are arbitrary and involuntary associations. ${ }^{54}$ Domestic legal systems exist within what Gunther Teubner calls a "high degree of institutional insulation" 55 and that insulation is the product of a political conception of the law centering on nation-states. Says Teubner, "[f]or nation-building in the past, unity of the law was one of the main political assets—a symbol of national identity. ..." ${ }^{56}$ These claims are not unique to Teubner, ${ }^{57}$ though he makes them in the context of

\footnotetext{
54. Nagel, supra note 14, at 128, 133, 146.

55. Teubner, Global Bukowina, supra note 13, at 3, 8.

56. Id.

57. Teubner, Global Bukowina, supra note 13, at 3. The connection of law and codification to national identity is not unique to Teubner. See, e.g., Michael John, Politics and Law in Late Nineteenth-Century Germany: The ORigins of the CiviL CODE 6-7 (1989) (“Codification was ... . widely regarded as an integral part of the process of state formation. ... F From the start of the nineteenth century, codification was linked to nationalism.”); R.C. VAN CAENEGEM, EUROPEAN LAW IN THE PAST AND THE FUTURE: UNITY AND DiVERSITY OVER Two MiLLENNIA 94 (2002), in the context of Germany:

No matter how strongly scholars disagreed about the merits of native vs. Roman law, their contest would not have been so dramatic if other, i.e., political, considerations had not been involved. The quarrel was so violent because it concerned political feelings. It was all about the very touchy issue of national against foreign law: what could have been more burning in the young, proud nation state? National pride, the ethnic interpretation of history and the
} 
supporting his claim that the law merchant is part of what he calls global law without a state. ${ }^{58}$ Teubner seems to be making a point about the historical conditions for unifying European law in the nineteenth century using the great civil codes of the time, ${ }^{59}$ but his points are sufficiently universal so that they can be reasonably applied to the American experience.

Related to the problem of arbitrary association is incompleteness: If we only consider domestic and state-created international sources for commercial law, a plausible argument could be made that we have a seriously incomplete picture of what commercial law consists in, and our answers to legal problems might be wrong. Indeed, norms that non-state actors create might be more important to commercial actors than statecreated norms. $^{60}$ The incompleteness point should be obvious to lawyers but I hope to make it clearer below.

Think of commercial law from the standpoint of the actors in the world who use it. Firms are increasingly multinational. This chapter is not the place to discuss law and globalization in a comprehensive way, but let's think of these questions from the interests of the sorts of clients our law graduates may represent. For firms to rely solely on U.S. markets is a risky strategy. A recent report in the Wall Street Journal of Hershey's exposure to the risk of being only in the domestic market illustrates the problem of a "domestic only" strategy. ${ }^{61}$ The business community saw Hershey's strategy as so unusual that it is news reported in the Wall Street Journal. Hershey is aware of its problems and is trying to expand to global markets through a potential business combination with Cadbury PLC, but that will be difficult because Hershey, relying only on U.S. markets, cannot finance such a combination and still retain control. Hershey's market, the U.S. market, is the largest domestic economy in the world by far, but still, to rely only on a domestic market for sales is risky. Hershey's competitors generate substantial revenues in markets globally, which they use to finance their operations.

Global business is such a common phenomenon today that MBA programs often require MBA students to complete a course in global

romantic Volkgeist theory formed a potent current from the late eighteenth century onwards.

58. Teubner, Global Bukowina, supra note 13; Teubner, Breaking Frames, supra note 13.

59. See JoHn, supra note 57.

60. Berman, supra note 24, at 1177-78.

61. Julie Jargon, Can Hershey Survive Candy Wars? Trust's "No Sale” Leaves Company Relying on U.S. as a Global Giant Looms, WALL ST. J., June 18, 2008, at B1. 
strategic management. ${ }^{62}$ As one of the core readings in such courses, written in 1989, explains to first year MBAs:

Many forces are driving companies around the world to globalize by expanding their participation in foreign markets. Almost every product market in the major world economies-computers, fast food, nuts and bolts-has foreign competitors. Trade barriers are also falling. . . . Japan is gradually opening up its long barricaded markets. Maturity in domestic markets is also driving companies to seek international expansion. This is particularly true of U.S. companies that, nourished by the huge domestic market, have typically lagged behind their European and Japanese rivals in internationalization. ${ }^{63}$

Firms are way ahead of law reformers and governments in understanding the need for thinking of commercial law transnationally. While Teubner tells us of the problem of institutional insulation, Hershey illustrates for us the problem of economic insulation. Karl Llewellyn and Grant Gilmore, the legal realists who were the prime movers of the UCC at its inception, with their emphasis on facts and context, would be international (or transnational!) lawyers in the twenty-first century.

What has been said so far in justification of a cosmopolitan perspective on commercial law comes only from North American or "large market" perspective. We can leave aside our biases and examine the issue from the standpoint of "small market" countries, be they a developing country, such as Uganda, or an industrialized country, such as Ireland. ${ }^{64}$ The conclusion is the same, but the facts make it all the more inevitable. These countries do not have the luxury of institutional or economic isolation. For a small market industrialized country, international transacting is a necessity; the country does not produce sufficient goods and services to maintain economic autonomy, and the country likely depends on exports to generate wealth for its citizens, since its domestic market is too small to do so. A developing country

62. See, e.g., Wharton Business School's curriculum, in particular its Global Strategic Management course. Core Curriculum, MBA Resource Guide, The Wharton School of the University of Pennsylvania, http://www.wharton.upenn.edu/mbaresource/ curriculum/core/index.cfm\#mgmt655 (last visited July 3, 2008).

63. George S. Yip, Global Strategy ... In a World of Nations?, 31 SLOAN MGMT. REV. 29 (1989). This article is required reading in Professor Stephen J. Kobrin's Global Strategic Management course at Wharton. http://www-management.wharton.upenn.edu/ OLD\%20WEB/CourseScreens/Syllabi/Spring2005/655_Kobrin_Spring05.pdf (last visited July 3, 2008).

64. Angelo Forte, The United Nations Convention on Contracts for the International Sale of Goods: Reason and Unreason in the United Kingdom, 26 BALT. L. REV. 50, 58 (1997) (Scottish and English interests diverge on the ratification of the Vienna Convention on the International Sale of Goods or CISG). 
faces similar issues, but we must add to the mix its institutional deficiencies. Developing countries often lack adequate judicial, law enforcement, and regulatory institutions. Purchase a book on Ugandan contract law, and it is likely that the book is full of English case law. ${ }^{65}$ Legal systems of many developing countries are simply too undeveloped to have generated a body of principles over the course of time, and lawyers in the country must be versed in the laws of other countries, usually that of the country's old colonial ruler. Public procurement officers for developing country governments must be well versed in international sale of goods law and other areas of international commercial law because supplies and services of any good or service of even a modicum of complexity or value have to be imported. Construction contracting is a substantial series of international legal events in developing countries.

Commercial lawyers, regardless of national origin, thus should have a thoroughly cosmopolitan perspective. If I am right, no rigid distinctions exist between the domestic and the international when conceptualizing commercial law as a legal category, though in the sphere of application to discrete legal problems for clients, certainly some problems will be wholly domestic in scope.

If we are to consider all possible sources for commercial law regardless of state borders, then at least eleven possible sources of commercial law exist: (1) municipal or domestic commercial legislation; (2) judgments by municipal courts interpreting domestic legislation; (3) municipal case law; (4) commercial treaties or conventions between and among states; (5) interpretations of international commercial treaties or conventions by municipal courts; (6) law merchant that private legislatures or rule-making bodies create, for either domestic or transnational transactions, which I call legislated law merchant; (7) interpretations of legislated law merchant by municipal courts; (8) interpretations of legislated law merchant by arbitrators; (9) "unwritten" law merchant or custom, which evolves but is not promulgated in a discrete rule-making event. I call this form of law merchant "evolved" or "customary" law merchant to distinguish it from legislated law merchant. As with the legislated version of the law merchant, the evolved version of the law merchant may be for wholly domestic markets or for transnational markets, though my examples below relate only to transnational markets; (10) interpretation and creation of evolved or customary law merchant by courts and arbitrators; and (11) general or fundamental principles of law. All of these need more explanation and clarification, particularly the law merchant

65. David J. BAKibinga, LaW OF CONTRACT In Uganda (2001). 
categories, which may not be self-evident. At this point, the list is stipulative and broad in the sense that it contains possible sources. And, given the breadth of the list, the discussion to follow can only be an incomplete sketch of the sources. One sense in which it is stipulative is its segregation of similar concepts, such as municipal case law and evolved law merchant, and municipal legislation and legislated law merchant. These segregations are designed to achieve clarity, and to avoid making assumptions about what requires conceptual justification. As well, the identification is conservative, staying close to the traditional conception of legal categories as they are understood in municipal legal systems. In addition, the discussion to follow merges some of these categories when they relate to each other.

Some of what I am about to say about the noncontroversial categories of commercial law may seem basic, but I want to lay out each of the categories, to make clear distinctions between them. This is necessary because the literature on the law merchant is often lacking in the sort of clarity strived for in analytical philosophy, and some writers have conceptualized the law merchant in loose and contradictory ways. ${ }^{66}$ As a result, the use of the phrase "law merchant" might be very different as between different lawyers, arbitrators, and legal scholars.

\section{A. Domestic Commercial Legislation}

First and most obviously is domestic legislation. The Uniform Commercial Code is an example of domestic legislation. The American commercial law codification movement began in earnest in 1892 with the creation by the American Bar Association, at the urgings of the New York Legislature, of the National Conference of Commissioners on Uniform State Laws (NCCUSL). ${ }^{67}$ Of course, the need for codification in the United States was obvious. M.D. Chalmers, one of the prime movers of English commercial law codification, said in 1903: "In the United States, the case for codifying mercantile law is stronger than in England. I am told that an American lawyer who wishes to keep abreast of the current of judicial decision has to take in some fifty-eight volumes of Law Reports ever year."68 Two waves of legislation ${ }^{69}$ culminated in

66. See infra notes 329-36 and accompanying text.

67. Uniform Law Commission: The National Conference of Commissioners on Uniform State Laws, http://www.nccusl.org/Update/DesktopDefault.aspx?tabindex=0\& tabid=11 (last visited July 3, 2008); see Mitchell Franklin, On the Legal Method of the Uniform Commercial Code, 16 L. \& ConTEMP. ProBs. 330 (1951).

68. M.D. Chalmers, Codification of Commercial Law, 19 L. Q. REv. 10, 17 (1903). I trust the reader sees why Chalmer's quote may be amusing to lawyers today!

69. See Robert Braucher, The Legislative History of the Uniform Commercial Code, 58 Colum. L. ReV. 798 (1958). 
the Uniform Commercial Code, the definitive version of which appeared first in 1957 and then with minor changes in 1958 and 1962. ${ }^{70}$

English law went through a codification movement in the nineteenth century similar to the movement that occurred in the United States, but unlike in the United States, which opted for wholesale reform through the Uniform Commercial Code, many of the English commercial statutes, with some piecemeal modification, remain in force today. ${ }^{71}$

Countries in the civil law tradition also have commercial codes. France's is the Code de Commerce of 1807, redrafted in 2000 and the Germany's is the Handelsgesetzbuch of $1900 .^{72}$ Some countries, such as Italy, the Netherlands, and Switzerland, have abolished commercial codes and regulate commercial transactions through their civil codes. ${ }^{73}$

It is beyond the scope of this article to discuss the differences in codification as between common law and civil law countries. Significant differences cut across several levels. A code in a civil law country is a very different institution from a code in a common law country. In addition, a commercial code in a civil law country exists within an established hierarchy in which it is subservient to the civil code in the event the two codes are inconsistent. ${ }^{74}$ The UCC differs substantially from a commercial code in a civil law country.

Covered here are only the potential sources of commercial law, but nothing has been said about scope. The question of scope identifies even more differences as between civil law and common law conceptualizations of commercial law. What activity does the notion of commercial law cover? The question becomes important when we attempt to compare commercial law notions in common law and civil law traditions. The civilians use the general criterion of commerciality to determine what gets classified as commercial law. ${ }^{75}$ Because the notion of commerciality governs what gets classified as commercial law,

70. James J. White \& Robert S. Summers, Uniform Commercial Code 3-5 (5th ed. 2000).

71. Robert Bradgate, Commercial LAW 10 (3d ed. 2000).

72. Jan H. Dalhuisen, Dalhuisen on Transnational and Comparative COMMERCIAL, FinANCIAL AND TRADE LAW 17 (3d ed. 2007).

73. Id. at 22.

74. Tomes have been so written. For an introductory treatment, see JoHN HENRY Merryman, The Civil LaW Tradition: An INTROduCtion to the Legal Systems of WESTERN EUROPE AND LATIN AMERICA 26-33 (2d ed. 1985).

75. DALhuisen on TransNational and Comparative Commercial, FinANCiAL AND Trade LAw, supra note 72, at 16-22; Jim C. Chen, Code, Custom, and Contract: The Uniform Commercial Code as Law Merchant, 27 TEX. INT'L L. J. 91, 94 (1992) (“The UCC is not a code in the Continental sense. Short of a 'preemptive, systematic, and comprehensive enactment of a whole field of law,' the UCC deviates from the Continental model of a strictly commercial code with special procedures and rules tailored for merchants.”) (citations omitted). 
commercial codes in civil law countries cover only the transactions of merchants and professionals. Common law countries do not rely on such over-arching ideas unconnected to solving a particular problem for a client, and with no conceptual difficulty classify transactions involving consumers, even when consumers are on both sides of the transaction, as commercial law. Indeed, a common law lawyer might find time spent trying to understand these demarcation issues as a waste of time because it is not action guiding in the context of solving a particular legal problem. In the United States, consumer bankruptcy is a core commercial law subject, but in a civil law country, it would not be so classified. The UCC is full of provisions relevant to consumer transactions and whether those provisions provide adequate protection to consumers is a question of considerable debate. ${ }^{76}$ As well, a substantial and primarily federal legislation protects consumers, and American law professors have no qualms about the inclusion of this legislation within the commercial law curriculum. ${ }^{77}$ The American commercial lawyer might spend much of her time inquiring about the effects of the law on consumers and still call herself a commercial lawyer. ${ }^{78}$ In the United States, commercial law scholars see as alien to their work divisions that would put consumers in a different legal category on their own. Still that does not mean that consumers are treated the same as merchants, and American lawyers tend to classify consumer issues for special coverage both inside and outside of the Uniform Commercial Code. ${ }^{79}$ The Article

76. See, e.g., Charles W. Mooney Jr., The Consumer Compromise in Revised U.C.C. Article 9: The Shame of it All, 68 OHIо ST. L. J. 215 (2007); Caroline Edwards, Article 2 of the Uniform Commercial Code and Consumer Protection: The Refusal to Experiment, 78 ST. JOHN’s L. REV. 663 (2004).

77. The federal legislation and implementing federal regulation by the Federal Trade Commission, where applicable, includes the Magnuson-Moss Warranty Act, 15 U.S.C. $\S \S 2301-2312$, and implementing regulations, 16 C.F.R. Parts 700-03; the Consumer Credit Protection Act, 15 U.S.C. §§ 1601-1693r and the Unfair Credit Practices Regulations, 16 C.F.R. §§ 444.1-.5. The Consumer Credit Protection Act includes the Truth in Lending Act (Title I), the Fair Credit Reporting Act (Title VI), the Fair Debt Collection Practices Act (Title VIII), and the Electronic Fund Transfer Act (Title IX); see, e.g., Donald F. Clifford, Non-UCC Statutory Provisions Affecting Warranty Disclaimers and Remedies in Sales of Goods, 71 N.C. L. REV. 1011 (1993).

78. Bankruptcy and consumer debt have been the subject of a substantial literature. Bankruptcy law has been the focus of particular attention in recent years. This is not the place for an exhaustive survey. For a sample of the bankruptcy literature, see CHARLES J. TABB, BANKRUPTCY ANTHOLOGy (2002). The 2008 financial crisis will prompt an even more intense consumer focus. See, e.g., Oren Bar-Gill \& Elizabeth Warren, Making Credit Safer, 157 U. PA. L. REv. 1649 (2009).

79. Francis J. Facciolo, Father Knows Best: Revised Article 8 and the Individual Investor, 27 FlA. ST. U. L. REV. 615 (2000); Marion W. Benfield, Consumer Provisions in Revised Article 9, 74 ChI. Kent L. Rev. 1255 (1999); Jean Braucher, Deadlock: Consumer Transactions Under Revised Article 9, 73 AM. BANKR. L.J. 83 (1999); Fred Miller, Consumers and the Code: The Search for the Proper Formula, 75 WASH. U. L. Q. 
2B project failed largely because it was seen as treating consumers unfairly. ${ }^{80}$ Even in English law, commercial and consumer law tend to be seen as distinct fields of inquiry; English statutes might not break out quite as clearly as they do in on the continent, but generally English law more clearly demarcates between the law governing merchants and the law protecting consumers than in the United States, at least as academic lawyers conceptualize the field. ${ }^{81}$

\section{B. Municipal Court Decisions Interpreting Domestic Commercial Legislation}

The second possible source of commercial law is domestic court decisions interpreting domestic legislation. These cases may or may not be decided within legal systems that recognize the concept of precedent. $^{82}$ For courts that do not create precedent, still, their decisions may be influential for other reasons having to do with ensuring consistency and uniformity in the law. ${ }^{83}$ That the holdings of these

187 (1997); Kathleen Patchel \& Amelia H. Boss, Consumer Transactions and the Code: Some Considerations, 51 Bus. LAW. 1343 (1996).

80. See Jean Braucher, The Failed Promise of the UCITA Mass-Market Concept and its Lessons for Policing of Standard Form Contracts, 7 SMALL \& EMERging Bus. L. 393 (2003); Jean Braucher, Briefing Paper for the National Conference of State Legislatures, March 2001, http://www ncsl.org/programs/lis/cip/CIPCOMM/braucher0301 htm (last visited July 4, 2008); Michael Rustad, Making UCITA More Consumer-Friendly, 18 J. MARSHALL J. COMPUTER \& INFO L. 547 (1999).

81. It is not unusual for British law professors to hold chairs in consumer protection law alone.

An example of the demarcation is secured transactions law, which in English law is known as credit and security law. In English law, there are two registries for security interests, one for security interests in property owned by individuals and the other for security interests in property owned by companies. Bills of Sales Act 1878; Bills of Sales (Amendment) Act 1882, as amended; Companies Act 1985 \$395, 396; Bradgate, supra note 71 , at $495-500$.

82. I avoid the simplistic notion that common law jurisdictions recognize the concept of precedent while civil law jurisdictions do not. These sorts of broad generalizations are often inaccurate because they fail to capture the nature of judicial decision-making. These concerns are well beyond the scope of this article. For a discussion of these issues by a German law professor, see Katja Funken, The Best of Both Worlds-The Trend Towards Convergence of the Civil Law and the Common Law System (July 2003). Available at SSRN: http://ssrn.com/abstract=476461 (last visited July 4, 2008).

83. Following a previous court decision because it is precedent is a different reason for following it because it is a well decided, just, fair, efficient, promotes consistency or uniformity in the law, and so on. To follow a decision because it is precedent means that "[t[he previous treatment of occurrence $X$ in manner $Y$ constitutes, solely because of its historical pedigree, a reason for treating $X$ in manner $Y$ if and when $X$ again occurs." Frederick Schauer, Precedent, 39 STAN. L. REv. 571, 572 (1987). The elucidation of the concept of precedent could go further by further specifying what it means to have a reason to treat $X$ in manner $Y$. If precedent is to have a mandatory feature, it must be more than a reason, it must be an overriding reason, something in the nature of a reason 
decisions serve as independent sources of the law is undisputed in common law countries and certainly plausible in civil law countries.

An example of how a court operating under this second category both "interprets" and "makes" commercial law is the Maine Supreme Judicial Court decision in Maine Family Credit Union v. Sun Life Assurance Co. of Canada. ${ }^{84}$ The principal issue in that case was whether a credit union that accepted for deposit fraudulently indorsed checks was a holder in due course and therefore not subject to defenses of the drawer, an insurance company that issued the checks to beneficiaries defrauded by the credit union's customers. A holder in due course of a negotiable instrument is someone who takes the instrument for value, without "apparent evidence of forgery or alteration," in good faith, and without notice of claims and defenses specified in UCC $\S 3-302(a){ }^{85}$ The Credit Union's holder in due course status depended on whether it met the good faith requirement. In 1990, the NCCUSL and the ALI revised Article 3 to reflect an objective good faith standard. ${ }^{86}$ Section 3103(a)(6) of the UCC now requires holders to prove good faith by showing "honesty in fact and the observance of reasonable commercial standards of fair dealing." ${ }^{\text {,7 }}$ The second part of the standardobservance of reasonable commercial standards of fair dealing-adds the objective element. $^{88}$ The prior definition only required the holder to prove "honesty in fact," a subjective standard, to show good faith. ${ }^{89}$ In interpreting the Code before the revision, with few exceptions courts

that at least in ordinary cases trumps all other reasons. Elaboration of these points is well beyond our scope here.

84. Me. Family Credit Union v. Sun Life Assurance Co. of Can., 727 A.2d 335 (Me. 1999).

85. UCC § 3-302(a); see also Any Kind Checks Cashed v. Talcott, 830 So.2d 160

(Fla. Dist. Ct. App. 2002).

86. White \& SUMMERS, supra note 70, at 522.

87. UCC § 3-103(a)(6).

88. WHITE \& SUMMERS, supra note 70, at 522.

89. In the early days of the UCC, the drafters disputed whether the test for good faith in UCC Article 3 should be objective or subjective. The subjective test prevailed until the latest revision in 1990. The apparent source of the difficulty is a nineteenth century English case, Gill v. Cubitt, 3 B. \& C. 466, 107 Eng. Rep. 806 (K.B. 1824), which applied an objective test of good faith. The 1945 UCC Permanent Editorial Board Recommendations expressly rejected Gill's approach. WHITE \& SuMMERS, supra note 70, at 522. Though U.S. lawyers have had difficulty with this case, English lawyers have not. Gill is not even cited in Roy Goode's foundational English Commercial law text, and subjective good faith is summarily stated to be the English law on the subject without any equivocation. See Roy Goode, Commercial Law 602 (1995). Here is not the place for extended discussion, but English law has historically had difficulties with the notion of good faith. Id. at 100-01. For an example of how practitioners might advise clients unfamiliar with English law, see Freshfields Bruckhaus Deringer, English LawPotential Hazards-Briefing (April 2006), www freshfields.com/publications/pdfs/2006/ 14422.pdf (last visited June 3, 2009). 
refused to incorporate an objective element into the good-faith standard. $^{90}$ But the addition of more words and standards to a statute does not necessarily mean that the statute becomes clearer or more certain. As the Maine Supreme Judicial Court explained in Maine Family Federal Credit Union, "The new objective standard . . . is not a model of drafting clarity." "91 The Code does not furnish a standard for "fair dealing" but the UCC Official Comments distinguish fair dealing, which is part of the good faith standard, from careful dealing, which is not. $^{92}$ It is up to courts to supply a standard. Maine Family Federal Credit Union provides the following:

The factfinder must ... determine, first, whether the conduct of the holder comported with industry or "commercial" standards applicable to the transaction, and, second, whether those standards were reasonable standards intended to result in fair dealing. Each of those determinations must be made in the context of the specific transaction at hand. If the factfinder's conclusion on each point is "yes," the holder will be determined to have acted in good faith even if, in the individual transaction at issue, the result appears unreasonable. Thus a holder may be accorded holder in due course status where it acts pursuant to those reasonable commercial standards of fair dealingeven if it is negligent-but may lose that status, even where it complies with commercial standards, if those standards are not reasonably related to achieving fair dealing. ${ }^{93}$

The case was on appeal from a jury verdict against the credit union. $^{94}$ Applying this standard, the court in Maine Family Federal Credit Union held that a jury could have found that the failure of the credit union to place a hold on uncollected funds exceeding $\$ 120,000$ drawn on an out-of-state bank fails to comply with the fair dealing requirement. ${ }^{95}$

\section{Domestic Common Law}

The third possible source of commercial law is domestic common law unconnected to statutes. UCC Section 1-103(b) provides: "Unless displaced by the particular provisions of [the Uniform Commercial Code], the principles of law and equity, including the law merchant and the law relative to capacity to contract, principal and agent, estoppel,

90. See Maine Family Fed. Credit Union v. Sun Life Assurance Co., 727 A.2d 335, 340-41 (Me. 1999).

91. Id. at 342.

92. See id. at 342-43.

93. Id. at 343.

94. Id. at 338 .

95. Id. at 343-44. 
fraud, misrepresentation, duress, coercion, mistake, bankruptcy, and other validating or invalidating cause supplement its provisions."96 White and Summers explain that "[i]t is neither possible nor desirable to put all (or even nearly all) commercial law into a code."97 Despite nationwide codification in the United States, a significant common law of commercial law still exists. Lender liability cases are a good example, ${ }^{98}$ as are cases involving marshaling of assets. ${ }^{99}$ The emerging unjust enrichment cases in which unsecured creditors have a claim in restitution against secured creditors upon which they have conferred benefits offer examples of the tension between a rigid Article 9 that preempts the field and the need for courts to achieve justice. ${ }^{100}$ Agency law can be understood as commercial law, and it is almost entirely the product of court decisions.

If we examine jurisdictions with codification not as preemptive as the UCC, we find even more case law. In English law there is a more frequent use of trusts in commercial contexts. The Quistclose trust is an example. ${ }^{101}$ In a Quistclose trust, funds lent for a specific purpose are held in trust for the lender, who in effect takes a security in the funds through the trust. With a trust in place, the lender's remedies are what in English law are known as proprietary remedies for the trust funds, as opposed to personal remedies for damages for breach of loan covenants. This is not the place for an extended discussion of how the Quistclose transaction would be structured in the United States. In the United States, the trust would likely be a security interest, and a creditor not pursuing Article 9 secured creditor status would bear significant risk of

96. UCC § 1-103(b).

97. WhITE \& SUMMERS, supra note 70, at 21.

98. See Gerald L. Blanchard, Lender Liability: LAW, PRActice AND PREVENTiOn (2nd ed. 2008).

99. See, e.g., In re Jack Green's Fashions for Men-Big and Tall, Inc., 597 F.2d 130 (8th Cir. 1979); In re Robert E. Derektor of Rhode Island, Inc., 150 B.R. 296 (Bankr. D. R.I. 1993); cf. In re The Computer Room, Inc., 24 B.R. 732 (Bankr. N.D. Ala. 1982); In re Corso Stein Enterprises, Inc., 79 B.R. 584 (Bankr. D. N.J. 1987).

100. See, e.g., Ninth Dist. Production Credit Ass'n v. Ed Duggan, Inc., 821 P.2d 788 (Colo. 1991); In re Win-Vent, Inc., 217 B.R. 803 (Bankr. W.D. Mo. 1997); Commerce Bank, N.A. v. Tifton Aluminum Co., Inc., 217 B.R. 798 (W.D. Mo. 1997); Knox v. Phoenix Leasing Inc., 35 Cal. Rptr. 2d 141 (Cal. Ct. App. 1994); Daniels-Sheridan Fed. Credit Union v. Bellanger, 36 P.3d 397 (Mont. 2001).

101. See Barclays Bank Ltd. v. Quistclose Investments, Ltd. (sub nom Quistclose Investments v. Rolls Razor) [1970] A.C. 567 (H.L.) (appeal taken from Eng. C.A.); Twinsectra Ltd. v. Yardley [1999] Lloyd's Rep. 438 (Eng. C.A.); THE QUISTCLOSE TRUST: CRITICAL EssAys (William Swadling ed. 2004). For a discussion from the perspective of English law of the role of equity in commerce, see Peter J. Millett, Equity's Place in the Role of Commerce, 114 LAW Q. REV. 214 (1998). 
loss in the event of the debtor's default or bankruptcy. ${ }^{102}$ On the other hand, the closest American transaction to the Quistclose trust just might be one that is an exception to the Article 9 filing requirement, that of control over a deposit account under UCC Section 9-104. ${ }^{103}$ Under Section 9-104, control of the collateral by the secured creditor substitutes for filing. ${ }^{104}$ But here we can see what a code can do. Moving the fund into a deposit account removes the trust concept from the discussion and radically alters the nature of the security.

\section{International Conventions}

Treaties are an obvious source of commercial law that nations enter to govern commerce. These treaties have a variety of labels. One such label is "international conventions" when they deal with transactional law, such as the Vienna Convention on the International Sale of Goods. ${ }^{105}$ In contrast, another label is "agreements" when they deal with the regulatory side of international trade, as in the free trade agreements, such as the WTO agreements. ${ }^{106}$ For purposes of simplification, I refer to the former simply as conventions. ${ }^{107}$

Nations have entered into many multilateral and regional conventions governing a wide range of commercial activity, from sale of goods to security interests in mobile equipment. ${ }^{108}$ Has anyone counted? There are so many. No doubt many a law professor who teaches basic international commercial law courses, such as international business transactions, have had the experience of a student coming to him or her,

102. Michael Bridge, The Quistclose Trust in a World of Secured Transactions, 12 O.J.L.S. 333, 345 (1992); Robert Stevens, Insolvency, in THE QUISTClOSE TRUST: CRITICAL ESSAYS, supra note 101, at 153, 166.

103. UCC § 9-104.

104. WHITE \& SUMMERS, supra note 70, at 775.

105. The Vienna Convention, also known as the United Nations Convention on Contracts for the International Sale of Goods (CISG), can be found at http://www.uncitral.org/uncitral/en/uncitral_texts/sale_goods/1980CISG html (last visited June 7, 2009).

106. For the legal texts of the World Trade Organization agreements, see http://www.wto.org/english/docs_e/docs_e htm (last visited June 7, 2009).

107. The notion of convention as used above is a very different use of the phrase "social convention" by philosophers to refer to a regularity groups of agents observe, such as holding cutlery a certain way. Michael Rescorla, Convention, THE STANFORD ENCYClOPEDIA OF PHILOSOPHY (Edward N. Zelta ed., 2008), available at http://plato.stanford.edu/entries/convention/ (last visited June 7, 2009).

108. One of the more recent commercial law conventions is the UNIDROIT Convention on International Interests in Mobile Equipment, known as the Cape Town Convention, which was signed in 2001 and came into force in January 2006. http://www.unidroit.org/english/conventions/mobile-equipment/main.htm (last visited June 7, 2009). 
and saying, "I had no idea there were so many laws and institutions working at the international level."

International conventions are state-created law. Some commentators, including Jan Dalhuisen, Ole Lando, and Clive Schmitthoff, ${ }^{109}$ classify international conventions as part of the law merchant. As explained below, I stipulate the law merchant as rules, principles, standards, or more generically, norms, if any, that come to exist entirely outside of the nation-state lawmaking apparatus. ${ }^{110}$ Such a source-based classification might be seen to contradict the uses of the phrase in the practices of arbitrators. Another criticism I anticipate is that I am engaging in "sources thinking," an often stated but unfounded complaint about legal positivism.

First, as to the question of meaning as used by arbitrators, the purpose of the classification is to get clear on the actual practices of how some commercial norms are actually produced. We need a way of understanding how states produce some norms and how non-state actors produce others. I do not think I am departing from actual use here. I am trying to clarify what I think has been made a mess by some commentators, a point addressed below. ${ }^{111}$

Second, as to the criticism of "sources thinking," if we are to understand the nature of commercial law at the transnational level, we must explore the features of institutions and governance structures relevant to commercial law. Source is not the focus, but institutional structure is. How commercial law is made is an important characteristic of commercial law, since commercial law has the potential to come from a diversity of sources, both within and outside nation-states, and from state and non-state norm making institutions. We could not make sense of commercial law without understanding these institutions.

As to identifying institutions, conventions are state-created law, and as such they are not created by so-called "private" legislatures. The use of the word "private" in the literature is confusing. ${ }^{112}$ If the term

109. Dalhuisen, supra note 72, at 146-96; Dalhuisen, Legal Orders and their Manifestation, supra note 17; Ole Lando, The Lex Mercatoria in International Commercial Arbitration, 34 INT'L \& CoMP. L. Q. 747 (1985); Clive M. Schmitthoff, The Unification of the Law of International Trade, in Clive M. SCHMitTHOfF's SELECT EsSAYS ON INTERNATIONAL TRADE LAW 170 (Clive M. Schmitthoff \& Jiarui Cheng eds. 1988).

110. See infra notes $145-85$ and accompanying text.

111. See infra part II.F.1.

112. There is an extensive law and economics literature on private legislatures. See, e.g., Alan Schwartz \& Robert E. Scott, The Political Economy of Private Legislatures, 143 U. PA. L. REV. 595 (1995) (National Conference of Commissioners on Uniform State Laws/American Law Institute in UCC context); Paul B. Stephan, The Futility of of Unification and Harmonization in International Commercial Law, 39 VA. J. INT’L L. 743 (1999) (intergovernmental organizations and other international organizations), $c f$. John 
"private" is used to designate a rule-creating body whose membership is comprised wholly of private actors with no state-sponsorship, then international conventions clearly are not the product of private legislatures. The main producers of commercial law conventions are UNCITRAL, the Hague Conference on International Law, and UNIDROIT. $^{113}$ States dominate the membership of all of these organizations. In fact only states can be members of these organizations. $^{114}$ The terminology often used to describe them is

Linarelli, The Economics of Uniform Laws and Uniform Law Making, 48 WAYNE L. REV. 1387 (2003).

113. United Nations Commission on International Trade Law, http://www.uncitral.org (last visited June 10, 2009); International Institute for the Unification of Private Law, http://www.unidroit.org (last visited June 10, 2009); Hague Conference on Private International Law, http://www hcch net/index_en.php (last visited June 10, 2009).

114. The United Nations General Assembly created UNCITRAL in Resolution 2205(XXI) of December 17, 2006. G.A. Res. 2205(XXI) (Dec. 17, 2006). The Resolution provides for membership by sixty states who are General Assembly members. http://www.uncitral.org/uncitral/en/about/origin.html (last visited June 10, 2009). Article 20 of the UNIDROIT Statute provides for membership by "governments." UNIDROIT Statute art. 20 (March 23, 1993). The UNIDROIT Web site explains that membership is "restricted to States acceding to the UNIDROIT Statute." http://www.unidroit.org/ english/members/main htm (last visited June 10, 2009). Article 2 of the Statute of the Hague Conference on Private International Law provides in relevant part:

1. Members of the Hague Conference on Private International Law are the States which have already participated in one or more Sessions of the Conference and which accept the present Statute.

2. Any other State, the participation of which is from a juridical point of view of importance for the work of the Conference, may become a Member. The admission of new Member States shall be decided upon by the Governments of the participating States, upon the proposal of one or more of them, by a majority of the votes cast, within a period of six months from the date on which that proposal is submitted to the Governments.

Statute of the Hague Conference on Private International Law, art. 2 (July 15, 1955), available at http://www hcch.net/index_en.php?act=conventions.text\&cid=29 (last visited June 10, 2009) [hereinafter Hague Statute].

Article 3 of the Hague Statute provides that a "Regional Economic International Organisation" comprised solely of states may also be members of the Hague Conference. Hague Statute, art. 3. Article 3(1) provides that "Member States of the Conference may... decide to admit also as a Member any Regional Economic Integration Organisation which has submitted an application for membership to the Secretary General.” Hague Statute, art. 3(1). As for eligibility requirements, Article 3(2) provides that a Regional Economic Integration Organisation "must be one constituted solely by sovereign States, and to which its Member States have transferred competence over a range of matters within the purview of the Conference, including the authority to make decisions binding on its Member States in respect of those matters." Hague Statute, art. 3(2). Article 3(9) defines a Regional Economic Integration Organisation" as "an international organisation that is constituted solely by sovereign States, and to which its Member States have transferred competence over a range of matters, including the authority to make decisions binding on its Member States in respect of those matters." Hague Statute, art. 3(9). The Statute also contains a number of provisions to police the ongoing eligibility of these organizations for membership. Hague Statute, arts. 3(4)-(8). 
intergovernmental organizations (IGOs), to distinguish them from nongovernmental organizations (NGOs). In IGOs, the states call the shots. Rule-making institutions that have no state participation, such as the International Chamber of Commerce (ICC), are NGOs when they participate as observers in the rulemaking within UNCITRAL, the main producer of international conventions. NGOs have observer status in UNCITRAL deliberations. In fact even states that are not UNCITRAL members have observer status. ${ }^{115}$ UNCITRAL's practice, however, is to admit representatives to working groups with full rights of participation, regardless of whether they represent UNCITRAL member states, but most represent states, as either members or observers. The ICC has had a privileged "consultative status" with the U.N. almost since the U.N. came into existence. ${ }^{116}$ But while the ICC is the most prominent private industry group involved in transnational lawmaking, ${ }^{117}$ it has no power to produce conventions on its own. ${ }^{118}$ It must participate in an IGO's process, something like prominent lobbyists participating in lawmaking in national capitals.

For those democratic states that are members of commercial lawmaking IGOs, the IGOs could be said to be indirectly democratic. That these IGOs are indirectly democratic is hardly fatal to the claim that they are public and not private legislatures. An executive branch agency, such as the U.S. Department of State Attorney Advisor for Private International Law, appoints IGO delegates for the United States, and other countries have similar arrangements. These delegates work in deliberating sessions to produce conventions that must be acceptable to the domestic body that delegated authority to them, and ultimately to a domestic legislature or some other domestic lawmaking body that must

The Statute is obviously designed to accommodate membership of supranational organizations, such as the European Union.

115. See http://www.uncitral.org/uncitral/en/about/methods_faq html (last visited June 10, 2009).

116. International Chamber of Commerce: Policy and Business Practices, http://www.iccwbo.org/policy/id3237/index html (last visited June 10, 2009); Guillermo Jiménez, The International Chamber of Commerce: Supplier of Standards and Instruments for International Trade, 2 UNIFORM L. REV. 284, 286, 292 (1996) ("The ICC has class 1 (top-level) consultative status with the United Nations, where it puts forward the views of business in industrialized and developing countries... ICC permanent representatives at the U.N. in New York and Geneva monitor developments affecting business within the U.N. and its specialized agencies...." ), quoted in RoY GoodE, HERBERT KRONKE, EWAN MCKENDRICK, \& JEFFREY WOOL,TRANSNATIONAL COMMERCIAL LAW 356-57 (2007).

117. GOODE, KRONKE \& MCKENDRICK, supra note 114, at 352.

118. But it does have authority to make other sources of law on its own and its instruments are sometimes more successful than those made through official state channels. See infra notes 181-95 and accompanying text. 
ratify the convention for it to become the law of the country. ${ }^{119}$ States in effect delegate a limited form of law making power to IGOs, and the IGOs produce a convention that has no effect for a state until accepted in the state's constitutionally mandated ratification process.

Commercial lawmaking IGOs serve important state functions. Despite criticisms, ${ }^{120}$ the conventions they produce are often superior to the alternative of private international law approaches to handling legal problems that cross borders. In fact one could say that conflicts approaches are being undermined by the proliferation of conventions and the law merchant as I stipulatively define it below.

A convention goes into force when a specified number of signatories ratify it. The terms of when it goes into force are defined within the Convention itself. A convention is in force only for states that ratify it, unless its provisions become so accepted by the community of states that they become customary international law. ${ }^{121}$

In U.S. law, most and perhaps even all commercial law conventions are self-executing, which means that they become law once ratified by the U.S. Senate, without the need for any domestic implementing legislation. ${ }^{122}$ The distinction is significant. If a convention is not selfexecuting, then it is the law of the land, but only as between states. If not self-executing, there must be the further step of Congress passing implementing legislation, and it is the implementing legislation, and not the convention, that courts apply in disputes involving private parties. ${ }^{123}$ If a commercial law convention is self-executing, then once ratified, it is as much a part of domestic law as any federal statute, and as a federal statute, may even preempt state law, such as the UCC. ${ }^{124}$

119. The ratification terminology may be inaccurate for some countries. The emphasis in the text is on the U.S. terminology, though I have tried to explain as generically as possible, e.g., discussing how ratification has to be by a legislature or other law making body. In the specific case of the United States, it would be the U.S. Senate.

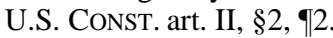

120. Citations to this critical literature as of about 2003 can be found at Linarelli, supra note 112, at 1409 .

121. Vienna Convention on the Law of Treaties, art. 24, May 23, 1969, 1155 U.N.T.S. 331, available at http://untreaty.un.org/ilc/texts/instruments/english/ conventions/1_1_1969.pdf; see MALCOLM N. SHAW, INTERNATIONAL LAW 835 (5th ed. 2003) ("It is quite clear that a treaty cannot impose obligations upon third states.... There is, however, one major exception to this and that is where the provisions of the treaty in question have entered into customary law.”) (footnotes omitted).

122. "The field of commercial law represents one of the most prominent examples of the influence of self-executing treaties.” Michael P. Van Alstine, Federal Common Law in an Age of Treaties, 89 CoRnell L. ReV. 892, 922 (2004), quoted in Amelia H. Boss, The Future of the Uniform Commercial Code Process in an Increasingly International World, 68 Оніо Sт. L. J. 349, 362 (2007).

123. Restatement (Third) of Foreign Relations § 111 (1987).

124. See Van Alstine, supra note 122, at 905-06. 
Commercial law conventions should be distinguished from model laws ${ }^{125}$ and legislative guides. ${ }^{126} \mathrm{~A}$ model law is not a formal agreement between countries in the form of a convention. Nor is it a legislative guide. They both require, however, substantive agreement as to content; otherwise they would not be approved in the IGO rulemaking process. They do not go through the ratification process of a convention. Rather, the model law is something for municipal legislatures to consider for enactment as municipal legislation, and a legislative guide is just that-a guide for municipal legislatures to use in drafting their own legislation. Ministries responsible for participating in international lawmaking for their governments often prefer model laws and legislative guides because these documents do not have to go through ratification processes and there is no worry about entry into force. Most model laws and legislative guides produced today are produced for consideration by developing countries in need of improving their legal institutions.

\section{E. Judicial Interpretations of Conventions}

Commercial law conventions are subject to interpretation just like domestic codes. The same concepts identified in Part II.B above apply mutatis mutandis here. It is by now well accepted that uniformity in the law is not achieved simply by promulgating a code or convention. Courts interpret conventions to decide cases, and interpretation in different state traditions has the potential to bring about divergences in interpretation. Divergence can occur even in the municipal courts of a single state.

Some conventions contain provisions like that of CISG Article 7(1), which provides that "[i]n the interpretation of this Convention, regard is

125. The laws of one country may be used as models for reform in other countries. It is still done to some extent, as, for example, the English commonwealth countries of Australia, Canada, and New Zealand have adopted UCC Article 9-like secured credit statutes, and England and Wales have considered doing the same thing. GERALD McCormack, Secured Credit Under English and American Law (2004). English commercial law statutes were used as models for the drafting of the first American uniform commercial law statutes. Williston explains that as for international standards on sales law, the English Sale of Goods Act was "the recognized statement of the common law, as distinguished from the civil law." Samuel Williston, The Law of Sales in the Proposed Uniform Commercial Code, 63 HARV. L. REv. 561, 564 (1950). The American Uniform Sales Act was "identical in most respects with the British Act." Id. at 563. It "followed the English statute both in substance and in the use of identical words." Id. at 564. See also Karl N. Llewellyn, The Needed Federal Sales Act, 26 VA. L. REV. 558, 558-59 (1940); Karl N. Llewellyn, On Warranty, Quality, and Society I, 36 CoLUM. L. REV. 699 (1936).

126. A recent example of a legislative guide is the UNCITRAL Legislative Guide on Secured Transactions, published in 2008. http://www.uncitral.org/uncitral/en/ uncitral_texts/payments/Guide_securedtrans html (last visited June 10, 2009). 
to be had to its international character and to the need to promote uniformity in its application and the observance of good faith in international trade." ${ }^{27}$ Other conventions contain substantially similar language. ${ }^{128}$ Further, CISG Article 7(2) provides, at least by implication, that courts should not rely on domestic law to interpret the CISG:

Questions concerning matters governed by this Convention which are not expressly settled in it are to be settled in conformity with the general principles on which it is based or, in the absence of such principles, in conformity with the law applicable by virtue of the rules of private international law. ${ }^{129}$

Some refer to interpretations of an international character as autonomous interpretations, meaning that they are independent of domestic law. ${ }^{130}$ It is beyond the scope of this article to explore these issues in detail. ${ }^{131}$ But

127. CISG art. 7(1), available at http://www.cisg.law.pace.edu/cisg/text/e-text07 html (last visited June 11, 2009).

128. See, e.g., UNIDROIT Convention on International Factoring, art. 4(1) (May 28, 1998), available at http://www.unidroit.org/english/conventions/1988factoring/main htm (last visited June 11, 2009) ("In the interpretation of this Convention, regard is to be had to its object and purpose as set forth in the preamble, to its international character and to the need to promote uniformity in its application and the observance of good faith in international trade.”); UNIDROIT Convention on International Financial Leasing, art. 6(1) (May 28, 1998), available at http://www.unidroit.org/english/conventions/1988 leasing/main htm (last visited June 11, 2009) ("In the interpretation of this Convention, regard is to be had to its object and purpose as set forth in the preamble, to its international character and to the need to promote uniformity in its application and the observance of good faith in international trade.”); UN Convention on Independent Guarantees and Stand-by Letters of Credit, art. 5 (Dec. 11, 1995), available at http://www.uncitral.org/uncitral/en/uncitral_texts/payments/1995Convention_guarantees _credit html (last visited June 11, 2009) ("In the interpretation of this Convention, regard is to be had to its international character and to the need to promote uniformity in its application and the observance of good faith in the international practice of independent guarantees and stand-by letters of credit.").

129. CISG art. 7(2), available at http://www.cisg.law.pace.edu/cisg/text/e-text$07 \mathrm{html}$ (last visited June 11, 2009).

130. See Franco Ferrari, The CISG's Uniform Interpretation by Courts-An Update, 9 VINDOBONA J. INT'L COM. L. \& ARB. 233, 239-40 (2005).

131. Others have done so. See, e.g., Larry A. DiMatteo, Lucien J. Dhooge, Stephanie Greene, Virginia G. Maurer, \& Marisa Anne Pagnattaro, InTERnational SAles LAW: A Critical ANALysis of CISG JuRisprudenCE (2005); Karen Halverson Cross, Parol Evidence Under the CISG: The "Homeward Trend" Reconsidered, 68 Оніо Sт. L.J. 133 (2007); Ferrari, supra note 130; Francesco G. Mazzotta, Why Do Some American Courts Fail to Get it Right?, 3 LoY. U. CHI. INT'L L. REV. 85 (2005); Harry M. Flechtner, The Several Texts of the CISG in a Decentralized System: Observations on Translations, Reservations and Other Challenges to the Uniformity Principle in Article 7(1), 17 J. L. \& CoM. 187 (1998); John E. Murray, Jr., The Neglect of CISG: A Workable Solution, 17 J. L. \& CoM. 365 (1998); Anthony S. Winer, The CISG Convention and Thomas Franck's Theory of Legitimacy, 19 Nw. J. INT'L L. \& Bus. 1 (1998); Franco Ferrari, The Relationship Between the UCC and the CISG and the Construction of Uniform Law, 29 LoY. L.A. L. REV. 1021 (1996); Lisa M. Ryan, The 
a sketch of the issues will help us to identify the nature of autonomous interpretation.

The issue is not whether a court may simply ignore a convention in favor of domestic law. There must first be a need for a judge to interpret a convention. Moreover, that interpretation must be inconclusively resolved by resort to the convention language alone. In some cases the issue is whether the court should then rely on domestic law to fill the gap in the convention or on foreign court interpretations of the convention. ${ }^{132}$ An example of a court refusing to rely on domestic law is MCC-Marble Ceramic Center, Inc. v. Ceramica Nuova D’Agostino, S.P.A., in which the Eleventh Circuit Court of Appeals held that the parol evidence rule found in UCC Article 2-202 does not apply to sales contracts to which the CISG applies. ${ }^{133}$ It is doubtful that the Court in MCC-Marble had to engage in any interpretative exercise, as CISG Article 8(3) seems to advise that the CISG does not contain a parol evidence rule. ${ }^{134}$ MCCMarble may be contrasted with Beijing Metals \& Minerals Import/Export Corp. v. American Business Center, Inc., in which the Fifth Circuit Court of Appeals stated in dictum that the parol evidence rule found in Texas law applied regardless of whether the CISG applied. ${ }^{135}$ In neither of these cases, nor in many other American cases, do courts look to foreign court judgments on the CISG for solutions.

Convention on Contracts for the International Sale of Goods: Divergent Interpretations, 4 Tul. J. INT'L \& COMP. L. 99 (1995); R.J.C. Munday, The Uniform Interpretation of International Conventions, 27 INT’L COMP. L. Q. 450 (1978).

132. Readily accessible English language sources for abstracts and digests of judicial decisions from other countries are now available, at least for the CISG. UNCITRAL publishes CLOUT, Case Law on UNCITRAL Texts, a collection of abstracts of court decisions on any UNCITRAL text. UNCITRAL has also prepared a Digest of the CISG case law. The Center for Comparative and Foreign Law Studies in Rome has prepared UNILEX, a collection of case law and a bibliography for the CISG. Ferrari, The CISG's Uniform Interpretation, supra note 130, at 242-44. Various web sites are very helpful, in particular Al Kritzer's CISG Database sponsored by Pace University School of Law. http://www.cisg.law.pace.edu/ (last visited June 11, 2009). Still, almost all of the translated material has to do with the CISG, and not much else. The CISG is, however, perhaps the more successful of the UNCITRAL conventions in terms of widespread ratification or accession.

133. MCC-Marble Ceramic Center, Inc. v. Ceramica Nuova D’Agostino, S.P.A., 144 F.3d 1384 (11th Cir. 1998).

134. CISG Article 8(3) provides: "In determining the intent of a party or the understanding a reasonable person would have had, due consideration is to be given to all relevant circumstances of the case including the negotiations, any practices which the parties have established between themselves, usages and any subsequent conduct of the parties.” CISG art. 8(3), available at http://www.cisg.law.pace.edu/cisg/text/e-text08 html (last visited June 11, 2009).

135. Beijing Metals \& Minerals Imp./Exp. Corp. v. Am. Bus. Ctr., Inc., 993 F.2d 1178, 1184-85 (5th Cir. 1993) (dicta). The contrast is suggested by DANIEL C. K. CHOW \& Thomas J. Schoenbaum, International Business Transactions: Problems, CASES, AND Materials 207-08 (New York: Aspen 2005). 
CISG Article 7 seems to advise that foreign judgments are even more "relevant" than UCC Article 2 or domestic contract law, in the sense that they might serve as persuasive authority or at least as information on how to interpret the CISG. Some scholars have even argued for a strict doctrine of precedent for foreign judgments deciding CISG issues. ${ }^{136}$ British courts have perhaps been more consistent cosmopolitans than their U.S. counterparts, at least in interpreting conventions. In Stag Line, Ltd. v. Foscolo Mango \& Co., Ltd., ${ }^{137}$ Lord Atkin explained that the Carriage at Goods by Sea Act 1924, which implements the Hague-Visby Rules in the United Kingdom, "is not intended to codify the English law, but is the result (as expressed in the Act) of an international conference intended to unify certain rules relating to bills of lading. It will be remembered that the Act applies only to contracts of carriage of goods outwards from ports of the United Kingdom, and the rules will often have to be interpreted in the courts of the foreign consignees." ${ }^{\text {"138 }}$ Lord Atkin, however, went on to express the need to focus on the language of the Act, a common law method of statutory interpretation. ${ }^{139}$ In Corocraft Ltd. v. Pan American Airways Inc., ${ }^{140}$ Lord Denning said of the Warsaw Convention: "[E]ven if I disagreed, I would follow [the decisions of foreign courts] in a manner which is of international concern. The courts of all countries should interpret [the Warsaw Convention] in the same way."

The CISG scholar John Honnold invented the phrase "homeward trend" to describe how courts interpret the CISG to defeat uniformity in international sales law. ${ }^{142}$ Legal scholars have used the phrase imprecisely. If it makes a hermeneutical claim that judges cannot help but work in their own national traditions, then it states a truism that would apply beyond the CISG context. ${ }^{143}$ Whether a threat to uniformity

136. DiMATTEO ET AL., supra note 131, at 2.

137. Stag Line, Ltd v. Foscolo Mango \& Co., Ltd. [1932] A.C. 328 (H.L. 1931) (appeal taken from Eng. (U.K.).

138. Id. at 342 (opinion of Atkin, L.).

139. Id. at 342-43.

140. Corocraft Ltd. v. Pan Am. Airways, Inc., [1969] 1 Q.B. 616, 655 (C.A.).

141. Id. at 655 (opinion of Denning, M.R.), quoted in INDIRA CARR \& PETER STONE, INTERNATIONAL TRADE LAW 72, 235-236 (3rd ed. 2005).

142. Cross, supra note 131, at 136-37 (quoting JOHN O. HonNold, DocumENTARY History OF THE Uniform LAW FOR InTERnAtional SAles: The StUdies, Deliberations, and Decisions That Led to the 1980 United NATIONS Convention WITH INTRODUCTIONS AND EXPLANATIONS 1 (1999)). John Murray uses the phrase “domestic legal lens." Murray, supra note 131, at 367, quoted in CARR \& STONE, supra note 138 , at 72 .

143. This seems to be Honnold's use of the phrase. Honnold says:

The Convention, faute de mieux, will often be applied by tribunals ... who will be intimately familiar with only their own domestic law. These tribunals, regardless of their merit, will be subject to a natural tendency to read the 
results is an empirical question. Not all judges are susceptible to it, as explained above. Another meaning of the phrase is that legal texts alone cannot produce uniformity. ${ }^{144}$ A uniform application of the text does not necessarily follow from the uniformity of the text. But this is true for any legislative or regulatory enactment, from legislated law merchant to domestic codes. It has no uniqueness for conventions, except perhaps that in the domestic context, judges work in the same national tradition, and hence the possibility of uniformity is greater. Another meaning of the phrases is that when judges are confronted with an opportunity to fill a gap in the CISG, they tend to fill it with their own domestic law. Another meaning of the phrase is that judges ignore CISG Article 7. Yet another meaning: judges are reluctant to use foreign court judgments. Finally, another meaning is that uniformity will be defeated unless judges consult court judgments of other countries. ${ }^{145}$ We can continue to digress on the question of what "homeward trend" means. Its meaning likely will combine several of these possibilities.

\section{F. Law Merchant}

A good deal of confusion persists as to what the law merchant actually is, if it exists at all. In this section, I attempt to clarify the field. Section 1 examines the ways in which commentators have conceptualized the law merchant. In section 1, I identify the sources of the confusion. Sections 2 through 4 provide my own elaboration of possible law merchant categories.

\section{Competing Definitions}

No settled definitions of the contemporary law merchant exist. To the contrary, a diversity of conceptions dominates the literature. In their influential book on International Chamber of Commerce arbitration, W. Laurence Craig, William Park, and Jan Paulsson suggest three possible meanings:

First, the most ambitious concept of lex mercatoria is that of an autonomous legal order, created spontaneously by parties involved in

international rules in light of the legal ideas that have been embedded at the core of the intellectual formation. The mind sees what the mind has means of seeing.

HonNOLD, supra note 141, at 1, quoted in Cross, supra note 131, at 136-37.

144. Many have said this. Ferrari calls it "common knowledge.” Ferrari, The CISG's Uniform Interpretation, supra note 130, at 233.

145. Vikki M. Rogers \& Albert H. Kritzer, A Uniform International Sales Law Terminology, 13 www.jus.uio no/sisu/a_uniform_international_sales_terminology.vikki_ rogers.and.albert_kritzer/portrait.pdf (last visited Aug. 5, 2008). 
international economic relations and existing independently of national legal orders. Second, lex mercatoria has been viewed as a body of rules sufficient to decide a dispute, operating as an alternative to an otherwise applicable national law. Third, it may be considered as a complement to otherwise applicable law, viewed as nothing more than the gradual consolidation of usage and settled expectations in international trade. ${ }^{146}$

Klaus Peter Berger also suggests three possible meanings, which differ in some respects from Craig, Park, and Paulsson's:

Some authors use the term to denote a mere "legal mass" of rules and principles without any internal consistency or systematic quality. It merely serves as a complement to the otherwise applicable domestic law. .... A second view regards the lex mercatoria as the totality of trade usages that are refined according to the needs of international commerce and constitute a "factual jus commune. ... A third view regards the lex mercatoria as an independent, supra-national legal system which derives its justification and validity from its autonomous existence or through the principle of party autonomy as a meta-legal rule. ${ }^{147}$

Berthold Goldman, one of the most influential proponents of the existence of a contemporary law merchant, suggests that the different views as to the law merchant can be understood as either a wide view of the law merchant or a narrow view. ${ }^{148}$ The wide view is that of Ole Lando, Clive Schmitthoff, and others, in which the law merchant includes law from official government sources, as well as from trade and professional sources. ${ }^{149}$ The law merchant, under the wide view, includes public international law, conventions, general principles of law, "rules of international organizations," such as UNIDROIT Principles of International Commercial Contracts ${ }^{150}$ and the Principles of European Contract Law produced by the Commission on European Contract

146. W. Laurence Craig, William W. Park, \& Jan Paulsson, International Chamber of Commerce Arbitration 633 (3d ed. 2001), quoted in Christopher R. Drahozal, Contracting Out of National Law: An Empirical Look at the New Law Merchant, 80 Notre DAme L. Rev. 523, 529 (1997).

147. Klaus Peter Berger, The Creeping Codification of the Lex Mercatoria 40 (1999).

148. Berthold Goldman, Lex Mercatoria, 3 F. InTERnATIONALE 4-7 (1983).

149. Lando, supra note 109; Schmitthoff, supra note 109. The above list is modified from Lando.

150. UNIDROIT Principles of International Conmmercial Contracts (2004), http://www.unidroit.org/english/principles/contracts/main htm (last visited Aug. 16, 2008). 
Law, ${ }^{151}$ customs and usages, standard form contracts, and reports of arbitral awards, even though many of these are confidential and not publicized. The wide view drains the idea of the law merchant of any significance. When we classify all commercial law sources as within the law merchant, we remove any meaning from the law merchant as a distinctive concept. Goldman, however, supports the narrow view of the law merchant. He contends that one cannot define the law merchant by the "object of its constituent sources," 152 but rather, one must also look to its origin, which he says is in its customary and spontaneous nature. ${ }^{153}$ He also requires frequent use. Goldman says that standard form contracts are not law merchant unless they achieve the status of custom by frequent use. ${ }^{154}$

We could go on and look at the other many attempts at stipulating definitions of the law merchant, but the problems with all of these definitions are common to them all. I will spend little time on the difficulties with these definitions because they do not advance the project of this article, but just a few obvious points. First, the requirement or characteristic of spontaneity is highly suspect. Spontaneity is at best contingently a feature of the law merchant. It may give rise to norms in a narrow set of conditions, in particular, when the conditions for infinitely repeating games are present. ${ }^{155}$ Moreover, spontaneity does not necessarily result in rules about which people have what Hart calls a critical reflective attitude towards compliance and violation. ${ }^{156}$ Spontaneity more likely advises us on externally observed statistical regularities, such as habits. ${ }^{157}$ People do not care about deviations from statistical regularities unless they become rules associated with a critical reflective attitude. Spontaneity can likely fully explain a habit but not a rule. To explain a rule, we need something more, some account of the beliefs and attitudes of the norm users, which spontaneity cannot explain. I may not have a critical reflective attitude about putting my right shoe on first every day. Spontaneity might explain that habit. But spontaneity cannot explain why I wear dress shoes with a suit and sneakers with

151. The Principles of European Contract Law, (rev. ed. 1998), http://www.jus. uio no/lm/eu.contract.principles.1998/doc.html (last visited Aug. 16, 2008).

152. Goldman, supra note 148 , at 5 .

153. Others also make the spontaneity point. See Dalhuisen, Legal Orders and their Manifestation, supra note 17, at 129-30; Bruce L. Benson, The Spontaneous Evolution of Commercial Law, 55 S. ECON. J. 644, 644-45 (1989).

154. Goldman, supra note 148, at 6-7.

155. See Paul Milgrom, Douglass C. North, \& Barry Weingast, The Role of Institutions in the Revival of Trade: the Law Merchant, Private Judges, and the Champagne Fairs, 2 ECON. \& POLITICS 1 (1990).

156. HART, THE CONCEPT OF LAW, supra note 8, at 57.

157. What follows is my variation on Hart. Id. at 57-58. 
jeans, and why I would find it odd to see large numbers of people doing otherwise. Shoe wearing etiquette likely reflects a set of social rules about which people have formed a critical reflective attitude. Spontaneity, moreover, explain normativity because it is too unstable. What is spontaneous today will not be spontaneous tomorrow. And what truly is spontaneous in any event? The proponents of spontaneity as a feature of the law merchant fail to give definitions and examples. Spontaneity must be ruled out as a plausible basis for the existence and the authority of the law merchant.

Perhaps the way to cure these problems with spontaneity is Goldman's requirement of frequent use, which would work something like Hart's and Raz's requirement that a legal system be "in force," meaning that many people in the normative community in question generally but not always comply with the law merchant. ${ }^{158}$ So, the argument would go, spontaneity plus frequent use or the fact that norms are in force results in the law merchant. But these two features cannot support the idea of a system of norms that law merchant theorists advocate. What is missing is an institutional infrastructure in the nature of secondary rules, a subject discussed in Part III. ${ }^{159}$

Most commentators on the law merchant are comparativists or are trained in comparative law methods. They conflate the notion of content convergence with authority. Their strategy is to argue a content convergence thesis. ${ }^{160}$ The result is a never-ending circular discussion of

158. See infra notes $291-93$ and accompanying text.

159. See infra notes 279-364 and accompanying text.

160. Emmanuel Gaillard, Transnational Law: A Legal System or a Method of Decision-Making?, in Berger, The Practice of TransNational LAW, supra note 30, at 53. Gaillard's work is a classic example of a failure to properly identify the conditions for the law merchant's status as law. Gaillard says that the "primary debate" in the past was on "the very existence and legitimacy of resorting to rules other than those of a given legal system." Id. at 55 . He says the debate is now on (1) sources or content and (2) whether the law merchant should be restricted to a list or understood as a method. These are ill-formed questions. Galliard is of the view that the law merchant is defined by content and that it can derive itself from content of national law. Id. at 58. The list versus method issue is subsidiary to first issue, because it is about content too. Gaillard contends that method is important, and his method is traditional comparative law analysis of comparing rules and trying as best one can with lawyer's methods to understand these rules in context. On the issue of whether the law merchant is a "distinct legal system," Gaillard identifies four necessary features of a "genuine" legal system, which come down to his initial point that if you understand the law merchant from the standpoint of the comparative law methods he espouses, you will find a legal system. Id. at 59-65. For the reasons explained above, this cannot be so. Gaillard relies on domestic validity for transnational validity and confuses analogous content with validity.

Berger does something similar to Gaillard. His CENTRAL project is about the search for existence of a "third" legal system empirically, through repeated use of contract clauses and "reliance in mutual adherence" to them. Berger's work is rich with 
the legitimacy of the law merchant. Their inability to produce an adequate account is at least an indirect form of support for the positivist strategy employed here. ${ }^{161}$ They use the methods of comparative law to claim that the content of the law is converging across municipal legal systems, is the subject of increasing harmonization through conventions, and that harmonization has occurred as well through the law merchant. From this content convergence they argue that there must be a transnational commercial legal order. The comparative method leads them in some cases to argue that they are looking for the "common core" of legal systems. ${ }^{162}$ To clarify this argument, we can give it a more formal presentation. The content convergence thesis is as follows:

(1) The law of $w$ jurisdictions on subject $x$ contain the similar valid rule $y$.

(2) The law of $z$ international instruments (or other sources) also contain valid rule $y$.

(3) Therefore, there must be a valid rule $y$, existing independently of the $w$ jurisdictions and the $z$ international instruments.

This is poor logic. The conclusion does not follow from the premises. It is question begging.

Content convergence proponents may argue that I have performed a sleight of hand because I have converted their inductive claim into a deductive claim. They are attempting an inference to the best explanation, in which the conclusion is not "guaranteed" by the premises. ${ }^{163}$ So, their argument is one based on the best available evidence, with a probabilistic conclusion. Converting the reasoning into inductive form does not solve the problems with content convergence, as

institutional detail, but fails to establish a legal system. His project, like Gaillard's is content convergence. BERGER, CREEPING CODIFICATION, supra note 146.

Clive Schmitthoff argues that the law merchant "comes from” comparative law. He uses the phrase "common core" to describe the search for the law merchant. His account, too, is about content convergence. Schmitthoff, supra note 107.

161. Some law merchant theorists have criticized legal positivism as unable to explain the law merchant or transnational legal order. BERGER, CREEPING CODIFICATION, supra note 146, at 91, 103. Burman and Dresser pose the question as one between "autonomists" and "positivists,' and erroneously argue that to a positivist only national law is the source of law. Harold J. Burman \& Felix J. Dresser, The "New" Law Merchant and the "Old" Sources: Content and Legitimacy, in LeX MerCATORIA AND Arbitration: A Discussion of the New Law Merchant 60 (Thomas Carbonneau ed. rev. ed. 1998).

162. The apparent influences are the "common core" comparativists. See, e.g., Mauro Bussani \& Ugo Mattei, The Common Core Approach to European Private Law, 12 COLUM. J. EUR. LAW 339, 339-40 (1997).

163. See LARry Wright, Practical Reasoning 57-58 (1988); Larry Wright, Induction and Explanation, 4 PHIL. INQUIRY 1 (1982). 
their premises still fail support their inference. They still require some additional element explaining why content convergence leads to a new valid legal rule in a new legal system. Content convergence fails from the basic standpoint of logical coherence.

Content convergence fails because it confuses analogous content with validity. Many normative systems have analogous content, but that does not mean they are the same normative system. Law and morality, for example, may reflect the same or similar content, and one may influence the content of the other, but the conclusion does not follow that law is morality or morality is law. Morality may profoundly influence the content of the law, but the question of the validity of the law is not a question about whether the law is moral. ${ }^{164}$

Finally, the views of arbitrators for and against a law merchant are contradictory. ${ }^{165}$ European arbitrators, who tend to be academics, the "grand old men" of the profession, tend to support the idea of a law merchant. ${ }^{166}$ They come from a civil law tradition in which legal analysis is reasoned inquiry from the top to the bottom, from the general to the specific, in search of immanent legal principles. Their civil law backgrounds hardly explain their attitudes toward the law merchant. With the civil law tradition comes a strong connection of the law to national identity, and the values of reason, universalism, coherence, and completeness of an ordered and codified system. ${ }^{167}$ Though civilians use their styles of legal analysis to engage in teleological interpretation of code provisions that look general to the common law lawyer, these interpretations are governed by a notion of the ordered whole that comes out of code commentaries that fill in the details of the code. The civilian lawyer works in a structured environment in which the law is conceived as a complete normative system with all legal answers to be found in the code. It is puzzling why an academic lawyer working in such a tradition would be supportive of the law merchant, except perhaps to argue that it comes from the traditional professional role that academics play in civilian legal systems, of propounding the law through commentaries. In civilian legal systems, legal academics have historically had the more important role in producing and elucidating the law than the judges. ${ }^{168}$

The English and American common law lawyers who are arbitrators, on the other hand, tend to deny the existence of the law

164. HART, The CONCEPT OF LAW, supra note 8, at 185-212.

165. Berger characterizes the views not as contradiction but as an antimony of viewpoints. Berger, The Practice of Transnational LAW, supra note 30, at 32.

166. Dezalay \& Garth, supra note 17 , at 20-23.

167. There have been many expositions of these points throughout the years. See, e.g,, Pierre Legrand, Against a European Civil Code, 60 Modern L. Rev. 44 (1997).

168. See also Garth and Dezalay, supra note 17, at 41-42. 
merchant. ${ }^{169}$ They tend to be practitioners in the large Anglo-American law firms populating European capitals. ${ }^{170}$ They tend to see the law merchant as a way for "academics to avoid the rigorous analysis of the facts, the formal law, and even the terms of the contract."171 One of Bryant Garth's and Yves Dezalay's interviews for their book, Dealing in Virtue, was of a "well-known English QC from the commercial bar.","72 That QC said: "These people are just deciding by the seat of their pants. There's no such thing as the lex mercatoria." "173 As Lord Diplock said in Amin Rasheed Shipping Corp. v. Kuwait Insurance Co.:

The purpose of entering into a contract being to create legal rights and obligations between the parties to it, interpretation of the contract involves determining what are the legal rights and obligations to which the words use in it give rise. This is not possible except by reference to the system of law by which the legal consequences that follow from the use of those words is to be ascertained. ${ }^{174}$

Lord Diplock also said in that case:

Contracts are incapable of existing in a legal vacuum. They are mere pieces of paper devoid of all legal effect unless they were made by reference to some system of private law which the obligations assumed by the parties to the contract by their use of particular forms of words and prescribes the remedies enforceable in a court of justice for failure to perform any of those obligations. ${ }^{175}$

This rejection of the law merchant is puzzling, because common law lawyers would seem to be in a better position to understand legal evolution, and have greater tolerance for defects in the law in the forms of incompleteness, incoherence, lack of systematization, and so on.

Counterarguments may be posed against any of these claims about differences between the civil and the common law traditions. As Garth and Dezalay explain:

[E]ach side seeks to promote the value of the know-how or the competence that it has mastered the best. Academics-with a

169. For expositions of the English view, see Dalhuisen, Legal Orders and their Manifestation, supra note 17; Andreas F. Lowenfeld, Lex Mercatoria: An Arbitrator's View, 6 ARB. InT'L 133 (1990); L. Yves Fortier, The New, New Lex Mercatoria, or, Back to the Future, 17 ARB. INT'L 121 (2001).

170. Garth \& Dezalay, supra note 17, at 43.

171. Id. at 41 .

172. Id.

173. Id. at n. 19.

174. Amin Rasheed Shipping Corp. v. Kuwait Ins. Co., [1984] A.C. 50, 60 (H.L. 1983) (appeal taken from Eng.) (U.K.) (opinion of Diplock, L.).

175. Id. at 65. I will not comment on the question begging features of Lord Diplock's conclusions. 
competitive advantage in theory-emphasize the lex mercatoria elaborated in countless academic books and articles. Practitioners promote the virtues of solid case law and thorough analysis of the facts. ${ }^{176}$

Perhaps this is true, but if one has ever read a decision of a French court, with its emphasis on the syllogism, on only the essentials, and on brevity, one may see the point coming from sources deeper than that of the distinction between the academic and the practitioner. The differences likely come from differences in legal culture, not from professional roles played in a legal system.

We still have not gotten to the point of what the law merchant is. With some exceptions, the literature is written at a high level of abstraction and is vague on identifying law merchant norms. ${ }^{177}$ The differences between European and Anglo-American arbitrators may be partly dissolved by clarifying what the law merchant is comprised of. The above disagreement seems mainly to be about the classification of general principles of law or uncodified custom as law merchant. The differences in the continental and Anglo-American approaches to arbitration may rather be evidence of different approaches to adjudication in the civilian and common law traditions. Regardless of the nature of the disagreement about the role of the law merchant in arbitration, there is likely a good bit of uncontroversial territory, on say, the role and status of INCOTERMS or the UCP, rules created by nonstate actors, as law merchant. Acceptance of rules as "law merchant" or something else requires a good bit of work in clarifying terminology. And that is what this section purports to do.

The approach to ordering the law merchant here is drawn largely from the settled categories of the law found in state-created legal systems. I use concepts like legislation, case law, and general principles to order the law merchant. The language of state law reflects forms of normative practices that are well accepted by both the creators and the users of the practices. Schmitthoff offers a similar distinction between "international legislation" and "international commercial custom," but his international legislation includes norms that even states produce, such as conventions, domestic legislation, and model laws. ${ }^{178}$ He calls it

176. Garth \& Dezalay, supra note 17 , at 41-42.

177. There are counterexamples. Berger and Dalhuisen identify norms. BERGER, CreEPing Codification, supra note 146; DAlHUisen ON TrANSNATIONAL AND Comparative Commercial, FinANCial and Trade LAW, supra note 72, at 142-68, 20916, 219-37.

178. Schmitthoff, The Unification of the Law of International Trade, supra note 109, at 210 . 
"formulated custom." evolved practices of merchants and banks throughout the years. The organizations that make the law merchant he calls "international formulating agencies," but these go far into state dominated IGO territory, and the norm sets these organizations produce are not the law merchant in my conception, but rather are state-created law. ${ }^{180}$

\section{Legislated Law Merchant}

Legislated law merchant is sets of rules of a legislative or regulatory character, promulgated by non-state actors such as the International Chamber of Commerce in a legislative or regulatory setting. They are usually produced as a single document in the form or an enactment or publication. They are usually intended to be codifications of customary practices. ${ }^{181}$ They can include but are not limited to standard form contracts. They can be transnational or domestic. INCOTERMS and the Uniform Customs and Practices for Documentary Credits are transnational examples. ${ }^{182}$ Others are the Uniform Rules for Demand Guarantees and the Uniform Rules for Contract Bonds. ${ }^{183}$ I will focus on INCOTERMS and the UCP as standard examples familiar to most international commercial lawyers which are codifications of practices accepted for transborder transactions. Lisa Bernstein provides a number of domestic trade association examples in her work. ${ }^{184}$ Her merchant communities are tight-knit professionals in trade associations but

179. Id.

180. Id., at 212-18; Klaus Peter Berger, The New Law Merchant and the Global Market Place-A 21st Century View of Transnational Commercial Law, in THE PRACTICE of Transnational Law 7 (Klaus Peter Berger ed. 2001).

181. Telephone Conversation with Emily O'Conner, ICC Commission on Commercial Law and Practice (Sept. 29, 2008).

182. The abbreviation for the Uniform Customs and Practices for Documentary Credits is "UCP." INCOTERMS stands for "International Commercial Terms," but the abbreviation is so widely used that the full name has fallen out of use.

There are many other examples of legislated law merchant not explored above. Another prominent example is the rules and recommendations of the International Capital Markets Association, which "constitute the self-regulatory framework which ensures that tens of thousands of trades each day in international securities proceed smoothly to settlement.” http://www.icma-group.org/market_practice.aspx (last visited November 17, 2008).

183. Roy Goode, Herbert Kronke, \& Ewan McKendrick, Transnational Commercial Law 351 (Oxford: Oxford University Press 2007).

184. See Lisa Bernstein, Private Commercial Law in the Cotton Industry: Creating Cooperation Through Rules, Norms and Institutions, 99 MiCH. L. REV. 1724 (2001); Lisa Bernstein, The Questionable Empirical Basis of Article 2's Incorporation Strategy: A Preliminary Study, 66 U. CHI. L. REV. 710 (1999); Lisa Bernstein, Merchant Law in a Merchant Court; Rethinking the Code's Search for Immanent Business Norms, 144 U. PA. L. REV. 1765 (1996); Lisa Bernstein, Opting out of the Legal System: Extralegal Contractual Relations in the Diamond Industry, 21 J. LEGAL STUD. 115 (1992). 
merchant communities could be understood broadly, as, for example, all non-consumer buyers and sellers of goods, which is the traditional coverage of International Chamber of Commerce instruments such as INCOTERMS.

The nationalist would not classify these types of instruments as possible sources of law. They would, rather, say that these instruments are standard contract terms and conditions that become part of the law of the contract when they are incorporated by reference into a contract and are then governed by whatever national law applies to the contract, including conventions that the country whose law applied has adopted. ${ }^{185}$ They have such universally accepted status, however, that they reflect a normative practice independent from contractual incorporation. That is, if you ask a banker if they comply with the UCP, the answer will very likely be "yes," and not qualified by "only when incorporated into a contract." 186

INCOTERMS are standard terms and conditions for allocating delivery obligations between buyers and sellers in sale of goods contracts that cross international borders. They cover questions of who, as between buyer and seller, is to arrange for carriage, import and export regulatory matters, who buys insurance, and who has the risk of loss at different points in the transportation process. They are frequently used because they provide uniformity, certainty, and predictability to buyers and sellers in different countries. The "official" laws of nations have been notoriously deficient and lacking in uniformity on the issues that INCOTERMS covers. ${ }^{187}$ In 1936, the ICC stepped in to solve the

185. Jiménez explains:

With regard to the legal effect around the world of the ICC's rules for letters of credit, the basic rule is that the UCP rules are creatures of contract, and thus apply principally when they have been voluntarily incorporated by the parties. After more than 60 years of existence, the UCP has achieved such universal effect that in some countries, the UCP is recognised as having the force of law, or at least that of a strong trade custom. However, in other countries, such as the UK, the UCP does not have formal legislative status.

Jiminéz, supra note 116, at 292. Regrettably, Jiménez identifies no sources for the treatment by a state body of the UCP as the law of a state.

186. Jiménez, supra note 116,quoted in GOODE, KRONKE, \& MCKENDRICK, supra note 116 , at $356-58$.

187. The 2002 revision of UCC Article 2 eliminated references to delivery and payment obligations in the UCC. "The rationale for these changes is that the shipping terms as codified are out of date with commercial practice and any attempted codification of these terms would not keep in step with both domestic and international practice." Linda J. Rusch, Is the Saga of the Uniform Commercial Code Article 2 Revisions Over? A Brief Look at What NCCUSL Finally Approved, 6 DEL. L. ReV. 41 (2003). The Comments to revised Article 2 recommend reference to INCOTERMS. John E. Murray, Jr. \& Harry M. Flechtner, The Summer, 1999 Draft of Revised Article 2 of the Uniform Commercial Code: What Hath NCCUSL Rejected?, 19 J. L. \& Com. 1, 44 (1999). The 
problem through the promulgation of INCOTERMS. ${ }^{188}$ Merchant buyers and sellers of goods now rely on the 2000 version of INCOTERMS. ${ }^{189}$

The UCP is the codification of banking practices for the issuance and use of documentary letters of credit, which are commonly used as the primary means of trade financing in international sale of goods transactions. As Guillermo Jiménez explains, the UCP:

is frequently cited as the foremost example of how international business self-regulation can be more efficient than treaties, government regulation or case law. Indeed, legal commentators have called the UCP the most successful act of commercial harmonisation in the history of world trade, with the UCP 500 currently observed by banks in approximately 180 countries. ${ }^{190}$

Jiménez continues:

Near-universal adoption of the UCP in international trade and their incorporation into all relevant contracts . . . has had the result of producing, through a series of bilateral contracts, a multilateral network of contractual arrangements all based on a set of uniform rules by which the parties make their own law, which is largely independent of national legal systems. ${ }^{191}$

The International Chamber of Commerce published the first UCP in 1933, and has revised it regularly. ${ }^{192}$ The current version is known as UCP 600, which the ICC Commission on Banking Technique and Practice approved in October 2006, taking effect as of July 1, $2007 .{ }^{193}$ The UCP is widely accepted by bankers and contract parties. It is widely accepted as one of the most successful codifications of commercial practice. ${ }^{194}$ They, like INCOTERMS, are standard terms and conditions for incorporation by reference into letters of credit, but they also serve as standard practice regardless of incorporation. To understand the practice of using the UCP, consider what Barclays Bank says about the UCP on its website:

\footnotetext{
drafters are thus interested in promoting uniformity in domestic and international practices.

188. Murray \& Fletchner, supra note 131, at 44.

189. The latest version is INCOTERMS 2000 (Geneva: ICC 2000).

190. Jiménez, quoted in GoOdE, KRONKE, \& MCKENDRICK, supra note 116, at 357.

191. Id. at 358.

192. Janet Koven Levit, Bottom-Up Lawmaking Through a Pluralist Lens: The ICC Banking Commission and the Transnational Regulation of Letters of Credit, 57 EMORY L.J. 1147, 1170-71 (2008).

193. Id.

194. GoOde, KronKe, \& McKendrick, supra note 116, at 350-51.
} 
The majority of Documentary Letters of Credit are subject to a standardised code of practice formulated, and revised from time to time, by the International Chamber of Commerce (ICC) and known as "Uniform Customs and Practice for Documentary Credits." UCP is therefore made a part of the contract between the Importer and the Issuing Bank, between the various banks concerned in the Credit and between the banks and the Exporter.

Letters of Credit conforming to the current code should bear the clause "subject to Uniform Customs and Practice for Documentary Credits (latest version).",195

The ICC produces INCOTERMS, the UCP, and other norms using established procedures. The procedures are unwritten, at least in a public document, but they are well-established. The ICC seeks consensus from the various domestic chambers of commerce and other interested parties on rule changes. The revisions themselves reflect actual practices of relevant merchants and professionals and are worked into INCOTERMS and UCP revisions. The revisions are approved by a consensus procedure. Notably, they are valid only if produced according to these procedures. ${ }^{196}$

A less obvious yet still important source of legislated law merchant is the International Federation of Consulting Engineers, or FIDIC, standard terms and conditions for construction and related contracts. Some commentators call these the lex constructionis. ${ }^{197}$ International construction is a significant part of the global economy and the projects undertaken are complex. Construction poses tremendous risks for the contract participants and for also for communities who finance public projects and ultimately use the completed works. The World Trade Organization (WTO) Council for Trade in Services explains:

Construction is one of the oldest of all industries, retaining its role as a core economic activity from the early days of human civilization to this day. It not only provides the infrastructure for all other

195. Barclays Business Banking: Uniform Customs \& Practice for Documentary Letters of Credit, http://www.business.barclays.co.uk/BRC1/jsp/brccontrol?task=article group\&value=3448\&target=_blank\&site=bbb (last visited Aug. 15, 2008).

196. Emily O’Connor, supra note 181.

197. Gunther Teubner \& Andreas Fischer-Lescano, Regime-Collisions: The Vain Search for Legal Unity in the Fragmentation of Global Law, 25 MicH. J. INT’L. L. 999 (2004); Oren Perez, Using Private-Public Linkages to Regulate Environmental Conflicts: The Case of International Construction Contracts, 29 J.L. SoC’y. 77 (2002); Charles Molineaux, Moving Toward a Construction Lex Mercatoria: A Lex Constructionis, $14 \mathrm{~J}$. INT'L. ARB. 55 (1997). 
industries, but also constitutes one of the largest single sectors in the economy on its own. ${ }^{198}$

Philip Bruner describes the risks involved in international construction as follows:

International construction presents the greatest business risks (and presumably rewards) in the world. In undertaking to construct massive monuments to mankind's ingenuity in distant cities, jungles, deserts, mountains, and seas, international contractors confront a multitude of risks: (1) management of many multinational parties; (2) language barriers to communication; (3) variations in the availability, productivity, and skill of labor; (4) foreign customs and practices; (5) potential political and economic instability; (6) uncertainties of weather; (7) unexpected geologic conditions; (8) extended lines of communications and supply; (9) differing quality and suitability of building materials; (10) currency fluctuations and restrictions; (11) unfamiliar forms of disease, plant, insect and animal life; (12) different civil and criminal laws; (13) possible arbitrary government regulation; (14) difficulties in obtaining adjudication of claims and enforcement of contract rights; and (15) abnormal duration, size, and technical complexity of international construction projects. ${ }^{199}$

I have used "international construction" because that is the terminology the industry uses. But the use of the word "international" is imprecise in the construction context. The projects involve the use of standard form contracts written by a trade association with international membership but also rely on domestic law for gap fillers and recognition and enforcement of arbitral awards. Moreover, the projects are usually undertaken on the soil of a particular country, and sometimes the owner is a government or a public enterprise. Substantial domestic regulation is often the case. It is the nationality of the contractors based on their headquarters being outside of the country where the work is performed, and the multinationality of the projects, including the financing, that gives the project its international character. The kinds of projects for which FIDIC contracts are intended tend to be large-scale, such as the

198. WTO Council on Trade in Services, Construction and Related Engineering Services, Background Note by the Secretariat, June 8, 1998, S/C/W/38. The WTO is interested in construction because it is a possible area of future expansion for the General Agreement on Trade in Services Agreement (GATS). See World Trade Organization: Proposals for the new negotiations, http://www.wto.org/english/tratop_e/serv_e/ s_propnewnegs_e.htm (last visited Aug. 15, 2008).

199. Philip L. Bruner, Allocation of Risks in International Construction: Revisting Murphy's Law, The F.I.D.C. Conditions and the Doctrine of Force Majeure, 3 InT'L. CONST. L. REv. 259, 259-60 (1986). 
construction of major roads, airports, harbors, power generating facilities, waste disposal and sanitation facilities, and petrochemical plants. $^{200}$

Any unification that has occurred in construction law has been through the widespread use of FIDIC standard form contracts. As Thomas Stipanowich explains in the context of U.S. law and the U.S. domestic construction industry:

The transactional law of building design and construction stands in sharp contrast to the UCC approach to commercial transactions within its scope. In the private arena, there is no overarching codification or synthesis of public law defining and limiting the spectrum of transactions. Nor, until recently, was there significant professional or academic emphasis on construction law. ${ }^{201}$

Transnational construction norms come from "standardized contracts, technical guidelines and arbitration awards," with standardized contracts forming "the most important element in this discursive universe.",202 These standardized contracts profoundly effect "the formation of normative expectations" in international construction. ${ }^{203}$

Founded in 1913, FIDIC is the International Federation of Consulting Engineers. ${ }^{204}$ The acronym "FIDIC" is based on the French version of the name of the organization, "Fédération Internationale des Ingénieurs-Conseils." The folklore about FIDIC is that it chose to make its headquarters in Geneva, Switzerland, and to use the French name because it wanted to show that it was a truly international body not dominated by British engineers. As one commentator explains, "Although FIDIC is headquartered in Switzerland, the Red Book itself is firmly rooted in British law, both in the sense that it is fashioned for implementation in a common law system and that it incorporates peculiarly British notions of civil engineering construction contracting. ${ }^{\text {B205 }}$ Its historically most influential set of standard terms and

200. Perez, supra note 197, at 83.

201. Thomas J. Stipanowich, Reconstructing Construction Law: Reality and Reform in a Transactional System, 1998 WIS. L. REV. 463, 467-48 (1998) (footnotes omitted).

202. Perez, supra note 197, at 84.

203. Id.

204. International Federation of Consulting Engineers, http://www1 fidic.org/ federation/ (last visited Aug. 15, 2008).

205. M. Beth Lyon, The Role of the Consulting Engineer in Developing Country Construction Under the FIDIC Form Contract, 26 LAW \& POL’y INT’L Bus. 273 (1994).

FIDIC's Statute specifies “FIDIC” as its acronym regardless of the language used for its full name. Fédération Internationale des Ingénieurs-Conseils. Statutes and ByLaws, International Federation of Consulting Engineers, Art. 1 (October 2005), http://www1 fidic.org/about/statutes.asp (last visited Aug. 15, 2008). 
conditions, the so-called Red Book, is based on the domestic standard form contract of the British Institution of Civil Engineers (ICE). ${ }^{206}$ ICE, moreover, was instrumental in starting FIDIC. British engineers have traditionally dominated as consulting engineers on international construction projects starting in the nineteenth century and continuing well into the twentieth century.

FIDIC membership is comprised of national associations of consulting engineers. As the FIDIC website explains:

FIDIC . . . represents the international business interests of firms belonging to national Member Associations of engineering-based consulting companies. As such, the Federation represents the

As Hani Sarie-Eldin explains in the context of using the FIDC contracts in the Middle East:

FIDIC conditions are inspired by the Institute for Civil Engineers (ICE) form, which, in turn, was based on English law concepts and construction industry practice in the United Kingdom. Thus, FIDIC conditions are based on U.K. domestic contract law. The changes made to transform the domestic form (ICE) to an international form (FIDIC) were, except for a few, insubstantial. Professor [Ian Duncan] Wallace has clearly pointed out this problem in his comment on FIDIC conditions, stating that: "There has ... been far too little internationalization of the contract in this sense, which remains far too domestically English in character and language.”

In addition, the general practice in some Arab countries (for example, Kuwait, Saudi Arabia, and the United Arab Emirates-Abu Dhabi) is to use the Arabic language for the language of the contract and its documents, including the FIDIC conditions. According to such practice, the contract is constructed and interpreted in accordance with Arabic, not English, which is the origin language of the document. On this point Professor Wallace notes that "the contract is so unremittingly and peculiarly English in its language and concepts at a number of points, that the task of any translator becomes impossible without a profound knowledge of English law and industrial practices." Therefore, it is not surprising to find a considerable number of disputes due to the contradiction between the English version and an inaccurate Arabic translation.

To sum up, on many occasions the intended aims of the FIDIC clauses supported by the English legal system and U.K. construction industry practice may lead to a different result for the same FIDIC clauses governed by Egyptian law or any other Arab country's laws.

Hani Serie-Eldin, Operation of FIDIC Civil Engineering Conditions in Egypt and Other Arab Middle Eastern Countries, 28 InT'L LAW 951 (1994) (footnotes omitted). In response to these worries, FIDIC has promulgated contract documents based on the civil law and in different languages. For a discussion of FIDIC and the civil law, see Hubert Andre-Dumont, The F.I.D.I.C. Conditions and Civil Law, 5 InT'L. Const. L. Rev. 43 (1988).

206. NAel G. BunNi, The FIDIC Form of Contract: The Fifth Edition of the Red BоoK 3-4 (2nd ed. 2005). 
business interest of firms supplying technology-based intellectual services for the built and natural environment. ${ }^{207}$

Member associations must require that their individual members meet quality and ethical requirements set forth in the FIDIC Statute. ${ }^{208}$ Current FIDIC membership is comprised of 64 member associations, which in turn are comprised of about 56,000 professional engineers. ${ }^{209}$ Firms and other organizations may join FIDIC as affiliate members if their country has no national association or they do not qualify to belong to the national association. ${ }^{210}$ Individuals are not FIDIC members but can be correspondents in countries that do not have member associations. ${ }^{211}$

FIDIC established a Contracts Committee in its year of inception, 1913. ${ }^{212}$ From 1913 until 1993, FIDIC limited its contract drafting to three sets of contracts: the Red Book, the Yellow Book and the White Book. ${ }^{213}$ FIDIC standard form contracts are known in shorthand by the colors of their covers. FIDIC's most used standard form contract is the "Red Book," the official name of which is "Works of Civil Engineering Construction." 214 The Red Book has been used mainly for large traditional construction projects. It is in its fourth edition, which was first published in 1987 and then amended in 1988 and 1992. ${ }^{215}$ In 1999, FIDIC published another set of contract conditions to replace the Red Book. $^{216}$ The replacement is labeled as a first edition, so the fourth edition Red Book remains available. The Yellow Book, "Electrical and Mechanical Works," is in its third edition, dating from 1987, and was first published in $1963 .^{217}$ Its primary use is in the construction of industrial sites. ${ }^{218}$ The White Book, "Client/Consultant Agreement," is

207. International Federation of Consulting Engineers, http://www1 fidic.org/ federation/ (last visited Aug. 15, 2008).

208. International Federation of Consulting Engineers, Statutes and By-Laws art. 3 (Oct. 2004)

209. International Federation of Consulting Engineers, http://www1 fidic.org/ federation/ (last visited Aug. 15, 2008).

210. International Federation of Consulting Engineers, Statutes and By-Laws art. 4 (Oct. 2004)

211. Id. at art. 17.

212. BunNI, supra note 205, at 441.

213. Id.

214. FIDIC Forums: Contracts, http://www1 fidic.org/resources/contracts/default.asp? back=/resources/default.asp (last visited Aug. 15, 2008).

215. http://www1 fidic.org/bookshop/prod_page.asp?productcode=FC-RB-A-AA-10 (last visited Aug. 15, 2008).

216. http://www1 fidic.org/bookshop/prod_page.asp?productcode=FC-RA-A-AA-09 (last visited Aug. 15, 2008).

217. BunNI, supra note 205, at 441; http://www1 fidic.org/bookshop/prod_page.asp? productcode=FG-AV-B-AA-10 (last visited Aug. 15, 2008).

218. Perez, supra note 197 , at 88. 
in its third edition, dating from 1998, and was first published in $1990 .^{219}$ There are now many other standard contracts, including the Orange Book, "Design Build and Turnkey," the Silver Book, "EPC and Turnkey Projects," and various other standard form contracts that may not be known by the color of their covers. ${ }^{220}$ The newer contracts, particularly the Orange and Silver Books, reflect new thinking by FIDIC. The Orange Book reflects a trend towards classifying construction contracts based on allocation of responsibilities rather than on project type. The Silver Book is based on a completely new model. It is a two-party contract (employer-contractor) in which the engineer has no role. ${ }^{221}$ The Silver Book is designed for BOT and BOO projects, which reflect different roles for the parties and introduces the concessionaire as the party who takes responsibility for financing, construction and operation until the financing is paid off. ${ }^{222}$ FIDIC publishes its popular contracts in many languages, depending on need. The Red Book, for example, is published in English, Arabic, Chinese, Croatian, French, Hungarian, Laotian, Polish, Russian, Spanish, Thai and Turkish. ${ }^{223}$

These books are frequently used globally. As Nael Bunni explains, the Red Book "has . . . been used continuously more than any other form in the international scene for over 30 years."224 The World Bank and other international development institutions require the use of the Red Book, and other FIDIC books, modified to meet their particular needs, as standard terms and conditions in construction contracts that they fund. ${ }^{225}$ FIDIC dominates in the production of norms for international construction.

FIDIC has a sophisticated governance structure. One of the tasks undertaken in this structure is the care and maintenance of FIDIC contracts. The FIDIC By-Laws provide for a system of Standing or Liaisons Committees, answerable to the Executive Committee. FIDIC has created the Contracts Committee, a standing committee whose

219. http://www1 fidic.org/bookshop/prod_page.asp?productcode=FG-AV-B-AA-10 (last visited Aug. 15, 2008).

220. International Federation of Consulting Engineers Bookshop, http://www1 fidic.org/bookshop/default_contracts.asp\#collection (last visited Aug. 15. 2008). "EPC" means "engineering, procurement, construction."

221. Perez, supra note 197, at 91.

222. Id. at 92. "BOT" stands for "build operate transfer" and "BOO" stands for build operate own." For more on these kinds of arrangements, see John Linarelli, Private Participation in Public Projects: Some Strategic Issues, in, Public Procurement: Global Revolution 259 (Sue Arrowsmith \& Arwel Davies eds. 1998).

223. Perez, supra note 197, at 92.

224. BunNi, supra note 205, at 108.

225. See World Bank, Standard Bidding Documents, Procurement of Works and User's Guide (World Bank May 2005). 
purpose is to draft and update FIDIC contracts. ${ }^{226}$ The Executive Committee is elected by the FIDIC General Assembly. ${ }^{227}$

In addition to the legislative functions within FIDIC itself, FIDIC contracts themselves have historically given the consulting engineer considerable power, in both contract management and in the system of resolving disputes in projects in which the contracts are used. FIDIC contracts are generally designed around the idea of what a "trusted civil engineer" would expect to see in the document, and how a trusted civil engineer would interpret it. ${ }^{228}$ Historically, the British-trained engineer "provided an efficient alternative to the use of the judicial system."229 Though in revisions of the Red Book, the powers of the engineer have changed towards making the engineer less an impartial dispute resolver and more an agent of the employer, ${ }^{230}$ the following description is reflective of the traditional role of the engineer in FIDIC contracts, and in particular in the fourth edition of the Red Book, which still is available for use in construction projects:

The engineer must also resolve most of the day-to-day differences of opinion which frequently occur in multi-million or multi-billion dollar projects involving years of work by multiple subcontractors. It is this broad spectrum of decisional powers, binding both the contractor and the employer, which makes the FIDIC engineer

226. The terms of reference for the Contracts Committee are as follows:

(1) To identify Conditions of Contract and other documents which, subject to the concurrence of the Executive Committee, should be prepared or updated by FIDIC.

(2) To establish task forces to draft each document and to guide them as required and to carry out a final review of the documents for submission to the EC.

(3) To liaise, in conjunction with the Secretariat, organizations interested in FIDIC's Conditions of Contract.

(4) To coordinate the handling of queries on the interpretation of the documents.

(5) To promote interest in seminars and workshops and to suggest topics and speakers as appropriate.

(6) To coordinate the handling of queries on the interpretation of the documents.

(7) To promote interest in seminars and workshops and to suggest topics and speakers, as appropriate.

(8) To liaise closely with the Assessment Panel for Adjudicators, a training operation for adjudicators.

See FIDIC, Contract Comm., http://217.197.210.21/about/comm/cc/.

227. See FIDIC, Statutes \& Bylaws, http://217.197.210.21/resources/statutes/ statutes_en_2007.pdf

228. BUNNI, supra note 205, at 73.

229. Lyon, supra note 205, at 291.

230. David Bateson, FIDIC-New 1999 Edition of the Red Book Impartiality of the Engineer, http://www1.fidic.org/resources/contracts/bateson_aug00.asp (last visited Aug. 15, 2008). 
"uniquely strong and independent." One engineer has commented that except under one clause, the Red Book merely authorizes the engineer to "express an opinion," not to make a decision. It seems that in many clauses of the Red Book, however, the engineer's opinion seriously affects the rights and duties of the contractor and the employer.

Additionally, under Clause 67, to which the commentator referred, the engineer is the authority by whom disagreements must be decided before they can be referred to arbitration. This second-stage of more formalized decision-making occurs infrequently. ... ${ }^{231}$

Under clause 67, if a dispute arises, one of the parties, the owner or the contractor, must first refer the dispute to the engineer. The engineer has a fixed number of days after receipt of written notice of the dispute to give notice of his decision. The engineer's decision is final unless one of the parties refers the matter to arbitration. A disappointed party has a fixed number of days from the date of notice of the engineer's decision to give notice of intent to arbitrate. Before actually commencing arbitration, the parties must try to settle their dispute amicably. ${ }^{232}$ The Red Book reflects a clear FIDIC preference for the engineer as the adjudicator of disputes, despite the engineer's hiring by the employer.

The World Bank mandates that its borrowers use its standard bidding documents for works projects the Bank funds. The Bank incorporates the FIDIC Red Book as standard terms and conditions into its bidding documents, with exceptions. ${ }^{233}$

FIDIC is not the only possible source of lex constructionis. Other private associations, such as the Engineering Advancement Association of Japan (ENAA), have produced important standard form contracts, yet none are as influential or as widely used as FIDIC contracts. ${ }^{234}$

Finally, another candidate for classification as legislated law merchant is the UNIDROIT Principles of International Commercial Contracts. $^{235}$ It is a contract code of sorts, prepared by a group of country representatives and observers in a working group under the authority of an IGO. UNIDROIT has substantial government representation, yet the Principles are not a convention, but one of their intended purposes is to serve as a "model for national and international

231. Lyon, supra note 205, at 276-77.

232. Red Book, Clause 67.

233. Standard Bidding Documents, Procurement of Works and User's Guide (World Bank May 2005), available at http://go.worldbank.org/IP4T44BOA0.

234. Perez, supra note 197, at 89.

235. Yet another candidate is the Principles of European Contract Law, http://frontpage.cbs.dk/law/commission_on_european_contract_law/ (last visited Oct. 10, 2008). 
legislators.”236 They are wonderfully drafted and an excellent source of principles of contract law for anyone interested in the comparative study of contract law. But they are unlikely sources of commercial law. They are the product of mainly legal scholars working under the auspices of an IGO. As Dalhuisen explains:

They are no more than products of a UNIDROIT committee and as such have at best persuasive power in terms of a restatement or as soft law. Their authority is hardly in their academic pedigree and content, and their legitimacy if any can only derive from their reflection of international fundamental principles or from the ability of the international legal practice to recognise itself in them and to accept their guidance. . . . To put it more crudely, short of them reflecting fundamental legal principle and mandatory international practice, only the market place can decide their ultimate fate. Ordinarily therefore, international trade and commerce have themselves here the last word. ${ }^{237}$

At most, the UNIDROIT Contract Principles can serve to inform the content of the law merchant and other commercial law sources. Their Preamble is ambitious in specifying that they "may be applied when the parties have agreed that their contract be governed by general principles of law, the lex mercatoria, or the like," or when the parties have failed to include a choice of law clause in their contract, or "interpret or supplement” either domestic law or "uniform law instruments." 238 Their inclusion in the law merchant ultimately may depend on whether one takes a wide or narrow view of the law merchant. Ole Lando, who takes a wide view, would classify the Principles as law merchant; ${ }^{239}$ Goldman, who takes a narrow view, might not, and perhaps Michael Joachim Bonell, the Chairperson of the Working Group that drafted the Principles, has the right view when he classifies them as a "hybrid." 240 Bonell continues:

Whether the UNIDROIT Principles of International Commercial Contracts are part of transnational law depends of course on the meaning one intends to give to this latter notion. If one adopts a

236. UNIDROIT Principles of International Commercial Contracts, Preamble, http://www.unidroit.org/english/principles/contracts/main htm (last visited Oct. 10, 2008).

237. Dalhuisen on Transnational and Comparative Commercial, Financial AND TRADE LAW, supra note 72, at 306.

238. UNIDROIT Principles of International Commercial Contracts, Preamble, supra note 236.

239. Lando, supra note 109.

240. Michael Joachim Bonell, UNIDROIT Principles and the Lex Mercatoria, in LEX Mercatoria and Arbitration: A Discussion of the New Law Merchant 240 (Thomas Carbonneau ed., rev. ed.1998) (1990). 
narrow definition whereby transnational law basically consists of generally recognised principles of law and trade usages, it may be difficult to consider the UNIDROIT Principles as a whole as failing in one category or the other. On the contrary, on the basis of a broader definition whereby transnational law includes virtually all principles and rules other than those established by a particular domestic law, the UNIDROIT Principles, like other "private" instruments such as INCOTERMS or the UCP, are definitely part of it. Yet regardless of the position taken on this point, it can hardly be disputed that, also with respect to the UNIDROIT Principles, what really matters is not so much their definition in theoretical terms but rather whether, and the extent to which, they may be applied in practice in lieu of or in addition to domestic law. ${ }^{241}$

Under my scheme of classification, the Principles are not rules produced by non-state actors, such as INCOTERMS and the UCP, because they do not come from a non-state source, nor are they a product of a merchant community. Bonell and Dalhuisen agree that what matters for the status of the Principles as law merchant is their use and eventual acceptance by normative communities as law.

3. Interpretations of Legislated Law Merchant by Judges and Arbitrators

Judges sometimes find themselves in a position of having to apply and interpret legislated law merchant. Two U.S. examples of such interpretations are BP Oil International, Ltd. v. Empresa Estatal Petroleos de Ecuador ${ }^{242}$ and St. Paul Guardian Insurance Co. v. Neuromed Medical Systems Support. ${ }^{243}$ In these cases, the courts held that when contract parties use terms found in INCOTERMS, but they have neither defined the terms in their contract nor expressly incorporated INCOTERMS into the contract by reference, INCOTERMS apply nonetheless. Arbitral panels have similarly so held. ${ }^{244}$ These cases are based on CISG Article 9(2), which provides:

241. Michael Joachim Bonell, The UNIDROIT Principles and Transnational Law, in Berger, the Practice of Transnational LaW, supra note 30, at 23-24.

242. BP Oil International, Ltd. v. Empresa Estatal Petroleos de Ecuador, 332 F.2d 333 (5th Cir. 2003), reh'g denied, No. 02-20166, 2003 U.S. App. LEXIS 13595 (5th Cir. Jan. 16, 2003), appeal after remand, No. 04-20911, 2008 U.S. App. LEXIS 914 (5th Cir. Jan. 16, 2008), cert. denied, 129 S. Ct. 105 (2008).

243. St. Paul Guardian Insurance Co. v. Neuromed Medical Systems Support, No. 00 CIV. 9344(SHS), 2002 WL 465312 (S.D.N.Y. Mar. 26, 2002).

244. ICC Arbitration Case No. 7645 of March 1995, available at http://cisgw3.law.pace.edu/cases/957645i1 html); Russian Arbitration June 6, 2000 Arbitration Proceeding 406/1998, available at http://cisgw3.law.pace.edu/cases/ 000606r1 html. These sources are from Clayton P. Gillette, The Law Merchant in the 
The parties are considered, unless otherwise agreed, to have impliedly made applicable to their contract or its formation a usage of which the parties knew or ought to have known and which in international trade is widely known to, and regularly observed by, parties to contracts of the type involved in the particular trade concerned. $^{245}$

Incorporation is not restricted to the CISG context. Even without such prompting by a state-produced source, courts will incorporate the law merchant. In Harlow and Jones Ltd. v. American Express Bank Ltd., the Queen's Bench held that the Uniform Customs and Practices (UCP) of the International Chamber of Commerce governs banking relationships even if not expressly incorporated by contract. ${ }^{246}$ Based on $^{2}$ comprehensive surveys of commercial practices, a team of European legal scholars headed by Klaus Peter Berger has compiled a set of "truus lex" principles of the contemporary law merchant. Principle I.2.2 is as follows:

The parties are bound by any usages to which they have agreed and by any practice which they have established between themselves. Unless agreed otherwise, they are considered to have impliedly made applicable to their contract or its formation a usage of which the parties knew or ought to have known and which in international trade is widely known to, and regularly observed by, parties to contracts of the type involved in the particular trade concerned. ${ }^{247}$

This principle does not distinguish between legislated and evolved law merchant. There are many other examples involving express contractual incorporation as well. ${ }^{248}$

To a lawyer bound to national traditions, this discussion is about incorporation of the law merchant into state law. The notion of incorporation has a long history. An early influential American decision on incorporation is Swift $v$. Tyson. ${ }^{249}$ Suppressing the questions of federalism the case is widely known for in American law, in Swift, Justice Joseph Story relied on a law merchant customary rule found in

Modern Age: Institutional Design and International Usages Under the CISG, 5 CHI. J. INT'L L. 157 (2004).

245. CISG art. 9(2), available at http://www.cisg.law.pace.edu/cisg/text/treaty.html (last visited Oct. 10, 2008).

246. Harlow and Jones Ltd. v. American Express Bank Ltd., 2 Lloyd’s Rep. 343 (QBD 1990).

247. CENTRAL List of Lex Mercatoria Principles, Rules and Standards, Principle I.2.2, available at http://www.Trans-Lex.org/903000.

248. Three possible forms of incorporation have presented themselves in the history of commercial law. These are covered in Part III below. See infra notes 297-316, 338-45 and accompanying text.

249. Swift v. Tyson, 41 U.S. 1 (1842). 
English cases, which upheld the principle of negotiability by permitting past consideration to serve as meeting the value element for holder in due course status. In so holding, he refused to rely on New York state court decisions, even though he was sitting in diversity. Well before the UCC came into existence, American sales and contract law incorporated custom. The comment to UCC $\S 1$-205 cites to the pre-UCC Uniform Sales Act $\S \S 9(1), 15(5), 18(2)$, and 71 as relevant prior incorporation provisions. ${ }^{250}$ The First American Restatement of the Law of Contracts, well-accepted as reflecting the "classical" view of contract law, permits incorporation. $^{251}$

Of course, the UCC is well-known for its "incorporation strategy." ${ }^{252}$ The UCC provides a hierarchy for course of dealing, course of performance and usages of trade, the three forms of custom the UCC explicitly recognizes. ${ }^{253}$ Contract terms are to be construed whenever reasonable as consistent with each other, but in the event that is not possible, express terms prevail over everything else, followed by course of performance, then course of dealing, then usage of trade, then UCC gap fillers themselves. But the UCC goes farther than simply recognizing these forms of custom as aids in interpretation of contracts. Llewellyn's plan was for the entire Code to reflect "good" custom facilitating exchange consistently with maxims of good faith. ${ }^{254}$

In Luke v. Lyde, Lord Mansfield said that the law of negotiable instruments was not the law of one country. ${ }^{255}$ His view was common in the eighteenth century, before commercial law became a national enterprise. At the time, commercial law was the law merchant and part of the law of nations. ${ }^{256}$ But Lord Mansfield's approach has been understood to work in the other direction, that he undertook to

250. UCC § 1-205 Comment.

251. Restatement (First) Contracts §§ 247, 248 (1932). Section 247, entitled, "when usage is operative upon parties,” provides:

A usage is operative upon parties to a transaction where and only where

(a) they manifest to each other an assent that the usage shall be operative, or (b) either party intends the effect of his words of other acts to be governed by the usage, and the other party knows or has reason to know this intention, or (c) the usage exists in such transactions and each party knows of the usage or it is generally known by persons under similar circumstances, unless either party knows or has reason to know that the other party has an intention inconsistent with the usage.

252. To my knowledge, this is Lisa Bernstein’s phrase. See Bernstein, supra note 184.

253. UCC § 1-303.

254. Alan Schwartz, Karl Llewellyn and the Origins of Contract Theory, in KRAUS \& WALT, supra note 27, at 42.

255. Luke v. Lyde, 2 Burr. R. 883, 887 (1759), quoted in Dalhuisen, Legal Orders and Their Manifestation, supra note 17, at 11, n. 15.

256. Morton J. Horowitz, The Transformation of AmErican LaW 143-44 (1978). 
incorporate commercial law into English law. English cases plainly advise that commercial law becomes an unfeasible concept without incorporation. Consider Goodwin v. Robarts, a nineteenth century case in which the issue was whether certain Russian and Hungarian government scrip was negotiable. ${ }^{257}$ Goodwin allowed his broker to retain possession of scrip belonging to him. The scrip promised to give bonds to the bearer after all installments had been paid with interest. Goodwin's broker pledged the scrip to a bank as security for a loan. The broker went bankrupt and the bankers sold the scrip. Goodwin sued the bankers. He argued that the scrip was not negotiable because it was not recognized as such by the law merchant. The Exchequer Chamber held otherwise on the content of the law merchant, and the House of Lords affirmed. Cockburn, C.J., said:

Having given the fullest consideration to this argument, we are of the opinion that it cannot prevail. It is founded on the view that the law merchant thus referred to is fixed and stereotyped, and incapable of being expanded and enlarged so as to meet the wants and requirements of trade in the varying circumstances of commerce. It is true that the law merchant is sometimes spoken of as a fixed body of law, forming part of the common law, as and it were coequal with it. But as a matter of legal history, this view is altogether incorrect. The law merchant . . . is neither more nor less than the usages of merchants and traders in the different departments of trade, ratified by the decisions of Courts of law, which, upon such usages being proved before them, have adopted them as settled law with a view to the interests of trade and the public convenience, the Court proceeding herein on the well-known principle of law that, with reference to transactions in the different departments of trade, Courts of law, in giving effect to the contracts and dealings of the parties, will assume that the latter have dealt with one another on the footing of any custom or usage prevailing generally in the particular department. By this process, what before was usage only, unsanctioned by legal decision, has become engrafted upon, or incorporated into, the common law, and may thus be said to form part of it. "When a general usage has been judicially ascertained and established," says Lord Campbell, in Brandao v. Barnett . . ., "it becomes a part of the law merchant, which Courts of justice are bound to know and recognise. ${ }^{258}$

257. Goodwin v. Robarts, LR 10 Exch. 337 (1875), aff'd, 1 App. Cas. 476 (1876). Much of what follows is influenced substantially by L.S. SEALY \& R.J.A. HoOLEY, COMMERCIAL LAW 22-24, 471-73 (4th ed. 2008).

258. Goodwin, LR 10 Exch. at 346. 
In a 1932 article in the Law Quarterly Review, Robert Chorley said that Cockburn's statements of incorporation "should be inscribed in letters of gold in every Court handling commercial litigation."259 Contemporary British commercial legislation generally accepts incorporation. ${ }^{260}$ Incorporation is so well-accepted that courts no longer cite authority to support it. ${ }^{261}$ Roy Goode explains, in words sounding like Cockburn's:

Of great importance as a source of obligation in commercial contracts are the unwritten customs and usages of merchants. The impact of these on the content and interpretation of contract terms cannot be overstated. It is, perhaps, this feature above all which distinguishes commercial from other contracts, a distinction not formally adopted by the law. The fertility of the business mind and the fact that a practice which begins life by having no legal force acquires over time the sanctity of law are key factors to which the commercial lawyer must continually be responsive. Is a particular document a document of title? The House of Lords may have said no, possibly more than once. But how long ago was the ruling given? Cannot it not now be said, in another time, that the acceptance of this document as a document of title in mercantile usage is so entrenched as to justify according it legal recognition as such? Is a payment instrument outside the Bills of Exchange Act negotiable? In principle yes, if so accepted by the mercantile community, which may happen immediately or only over time. ${ }^{262}$

From English and American law we can extend our search for incorporation to other countries, and also to international instruments as evidence of the trend. Civil law countries have tended to be hostile to incorporation. ${ }^{263}$

Judges are state officials and courts are state organs, so it might seem that this category deviates from the condition that the law merchant must derive only from non-state sources. But this category is needed because it reflects actual practice. It illustrates why conceptual restrictions on legal authority as only "public," as relating only to state officials, fails to account for the interaction of state and non-state actors.

259. Robert S.T. Chorley, Conflict of Law and Commerce, 48 L. Q. REV. 51, 55 (1932).

260. Sealy \& Hooley, supra note 257, at 23.

261. See, e.g., Harlow and Jones, supra note 246.

262. GOODE, COMMERCIAL LAW, supra note 89, at 14.

263. Dalmuisen on Transnational and Comparative Commercial, FinanCial AND TRADE LAW, supra note 72, at 149. A detailed examination of the reasons for this hostility is beyond the scope of this article. See supra notes 72-73 and accompanying text on the strong national identity sentiments associated with codification in the civilian countries. 
We have to account for the interaction else our categorization will be incomplete.

\section{Evolved Law Merchant and General Principles}

Is there any law merchant that is entirely customary? I use the term "customary" to refer to norms that are wholly uncodified, in other words, not codified even by non-state actors such as the ICC. The distinction between evolved and legislated merchant may not be as stark as my categorization suggests, as legislated merchant may be nothing more than codification of custom. ${ }^{264}$

Jan Dalhuisen provides a recent attempt to organize the law merchant around categories. I will basis my discussion on his work because I think it is a rigorous attempt to exhaustively identify the law merchant categories. Dalhuisen identifies three categories of relevance to the category of evolved law merchant: fundamental principles of law, general principles of law, and custom. ${ }^{265}$

Dalhuisen's fundamental principles include pact sunt servanda, detrimental reliance, apparent authority, select ownership principles, unjust enrichment liability, and good faith. ${ }^{266}$ He contends that these principles are "the essence and basis of the law of contract, agency, property, tort, and restitution." ${ }^{267}$ He also includes basic fiduciary duties as fundamental principles of law. Dalhuisen justifies fundamental principles of law as natural law. ${ }^{268}$ My approach, however, is positivist, which means that I rely on the claim that law draws entirely or mainly from social practices. Positivism also requires acceptance of the claim that law's validity or existence does not necessarily depend on something other than social practices associated with the law itself. A positivist cannot claim that Dalhuisen's fundamental principles are law, though she might claim, if she is an inclusive legal positivist, that in some cases fundamental principles not coming from a social source might identify valid legal rules. ${ }^{269}$ Dalhuisen, however, does not make the validation claim. This inquiry treads into Part III territory only to make the point

264. Emily O’Conner, supra note 181.

265. Left unaddressed is his argument for a hierarchy of norms, in which he argues against conflicts approaches to transnational commercial law because it leads to use of ill-suited domestic law rules. It is unnecessary to the analysis in this article.

266. See Tom Carbonneau, A Definition of and Perspective Upon the Lex Mercatoria Debate, in CARBONNEAU, supra note 240, at 11, 17 (how ICC arbitrators use good faith and others general principles of law).

267. Dalhuisen on Transnational and Comparative Commercial, Financial AND TRADE LAW, supra note 72, at 149.

268. Id. at 60, 102-03.

269. This is not the place to discuss inclusive versus exclusive legal positivism. For discussion, see the authorities cited in note 9, supra. 
that it is unlikely that Dalhuisen's fundamental principles can be customary law merchant unless they come from a social source. While these fundamental principles might operate as overarching principles when one does reflective equilibrium ${ }^{270}$ to provide normative justification for the content of more fine-grained legal rules, it seems implausible that they form an independent basis for a set of customary law merchant rules.

Dalhuisen also identifies lower order "general principles of law" which he says are "often deduced from comparative research; that is, from similarities in national law. ${ }^{, 71}$ As explained above, ${ }^{272}$ such a classification is a mistake. Looking for content convergence adds nothing to determining whether independent norms exist. It simply tells us that legal rules in different national systems are similar in content. Dalhuisen is not alone in making this mistake. It is a mistake common to many comparatively minded commercial lawyers.

Finally, Dalhuisen identifies custom as a law merchant category. He defines custom as:

a practice which is universal in the trade or a relevant segment thereof and can as such not be unilaterally withdrawn or changed except if it is in its nature, but would require an industry shift or even the other party's consent to be set aside in an individual case. ${ }^{273}$

Dalhuisen makes the right distinction between customary rules and habit. $^{274}$ The above definition, however, includes what I classify as legislated law merchant. Dalhuisen does not offer purely uncodified examples. Is there such a thing as pure uncodified custom that does not amount to some sort of overarching fundamental or general principles shared by state law? I do not make the claim that evolved law merchant exists or that it is law, but only that it is possible that it exists and that it should be evaluated for determining its status. There is likely plenty of uncodified specific industry custom out there that has raised to the level of rules and is not merely statistical irregularity or habit. We get puzzling facts in cases like A. Gay Jenson Farms Co. v. Cargill, in which farmers sold grain to an insolvent grain elevator on credit. ${ }^{275}$ Was this poor planning or reflective of an industry custom of not requiring advance payment or other financing? Empirical inquiry on specific

270. See supra note 47 for an explanation of reflective equilibrium.

271. DAlHuisen on Transnational and Comparative Commercial, FinANCial AND TRADE LAW, supra note 72, at 149.

272. See infra notes 161-79 and accompanying text.

273. Dalhuisen on Transnational and Comparative Commercial, Financial AND TRADE LAW, supra note 72, at 151.

274. Id. at 150 .

275. A. Gay Jenson Farms Co. v. Cargill, 309 N.W. 2d 285 (Minn. 1988). 
industries might provide some answers here, though longstanding trades tend to rely on standard form contracts, which are in the nature of codified custom, or what I classify as legislated law merchant.

One final question that the above initial classification of possible sources raises: can arbitrators create custom? It seems plausible to conclude that arbitrators usually find themselves in the position of at most having the authority to identify and interpret pre-existing custom in accordance with the intent of the parties. Custom arises from merchant practices. Absent a clear choice of the law merchant as the law of the contract, a very rare occurrence, arbitral panels risk having their decision found to be void as against public policy or ordre public in actions either to set aside or enforce the award. ${ }^{276}$ The only way around this problem seems to be if a state court accepts a content convergence argument, as in Pabalk Ticaret $v$. Norsolor, in which both the Austrian Supreme Court in the set aside action and the French Court of Cassation in the enforcement action held that the principle of good faith the arbitrators used, and which they said came from the law merchant and not from a conflict of laws analysis, was sufficiently similar to state law as to not violate ordre public. ${ }^{277}$ The arbitrators in the case did not have the power under the arbitration agreement to rule as amiable compositeurs or in equity. ${ }^{278}$

\section{THE CONCEPT OF COMMERCIAL LAW}

Using the above sources as background understandings of the state of commercial law, we can now go back to the question asked at the beginning of this article: can the case be made in the tradition of analytical jurisprudence for a system of transnational commercial law? So far, I have only described the plausible sources of commercial law. An attempt to understand commercial law as a transnational legal order requires an identification of what might get included in the concept of transnational commercial law, which is the subject of Part III. If we think of law only as state-centric, we might find the question of what gets included to be banal. But the identification of the above plausible sources casts doubt on the strength of state-centric positivist claims, though some parts of the above discussion also seem to confirm the

276. If the views of most common law judges are anything like those of Lords Diplock and Mustill, two prominent members of the British judiciary, one would not want to take before them for recognition and enforcement any arbitral award saying anything about the law merchant that the parties do not expressly incorporate into the contract. See Mustill, supra note 19; Amin Rasheed Shipping Corp. v. Kuwait Insurance Co., [1983] 3 W.L.R. 241, discussed supra notes 174-76 and accompanying text.

277. Pabalk Ticaret v. Norsolor, 24 InT'L LEgAL MATERIALS 360 (1985) (commentary by Emmanuel Gaillard).

278. Id. 
dominance of state law and institutions. Simply identifying the plausible sources, however, cannot serve as justification for conceptualizing commercial law as a transnational system. Identification of sources by itself informs us that we should not ignore these sources from the standpoints of usefulness, function, or relevance to clients lawyers might represent, but these instrumental features of the sources alone do not support the conclusion that a unified system of transnational commercial law exists. Identification of sources can just as well support the claim that commercial law exists across distinct normative systems dominated by state institutions.

The question to be addressed is whether a system of transnational commercial law exists, in the form of what Joseph Raz calls an institutionalized normative system, or what Neil MacCormick calls an institutional normative order. ${ }^{279}$ If so, how do the above-identified sources work in such a system? If the answer to the first question is yes, then we can claim that the "wide view" law merchant theorists, such as Ole Lando and Clive Schmitthoff, are right. We will discover, however, that they reach the conclusion in the wrong way, through comparative law methods, which answers questions only about legal content and not about legal validity. ${ }^{280}$ I am not convinced, however, that the answer to the first question is in the affirmative. Remember, the aim of this article is description. The limits of legal positivism are tested here, to see if it can account for transnational orders or tell us that we are on the wrong path of conceptualizing such orders.

I make the tentative case for a concept of transnational commercial law, but concede that my account is in tension with established legal positivist tenets. Given that tension, legal positivism runs the risk of becoming a provincial and outdated theory about municipal law in an era of pervasive globalization of the law. Institutionalized normative orders supporting the practical authority of almost all of the above sources can be found, but it does not follow that these orders form a legal system. Legal positivism gets it right in giving municipal legal systems an essential role in producing, applying, and enforcing commercial law. But legal positivism may need servicing to deal with the relationship of municipal legal systems to each other and to the multiple normative orders out there that do not rely on the state for their validity.

My account is in tension with two different accounts, legal pluralism and legal positivism. Though the state-centricity of legal

279. RAZ, PRACTICAL ReAson AND NoRMS, supra note 12, at 128-48; MACCORMicK, INSTITUTIONS OF LAW, supra note 33, at 21-37; see also NeIL MACCORMICK, QUESTIONING SOVEREIGNTY 1-15 (1999).

280. See supra notes $162-80$ and accompanying text. 
positivism is not explicit in positivist teachings, legal pluralists have criticized legal positivism for being an incomplete account only of state law. ${ }^{281}$ Legal positivists have used conceptual analysis to describe the logical features of municipal legal systems. Hart's central case of a legal system is that of a municipal legal system. ${ }^{282}$ As explained below, Raz's uniqueness conditions for a legal system all but in name qualify only municipal systems for inclusion. ${ }^{283}$ Opposing positivist accounts of the law are pluralist accounts, which do not locate within analytical jurisprudence, but are mainly sociological or anthropological. ${ }^{284}$ My account differs from the legal pluralist account in that I write in the tradition of analytical jurisprudence. I try to elucidate a cosmopolitan version of legal positivism that can account for the distributed and transnational features of commercial law. Analytical jurisprudence is in desperate need of a conceptual analysis that can account for law's globalization.

To develop a transnational concept of commercial law requires that we try to split positivism into two versions or conceptions. The first is the traditional or political conception of legal positivism, which seems to be the way positivism is understood in its mainstream. The other is a new or cosmopolitan conception of legal positivism, which no philosopher or legal scholar has attempted. ${ }^{285}$ The account to follow must do two things, revise positivism and apply the revised version to commercial law norms. ${ }^{286}$

\section{A. The Political Conception of Positivism and National Commercial Law}

I divide the inquiry here into two sections. The first section sketches out the political conception of positivism. It is only a sketch and I cannot provide here any comprehensive survey. The second section uses that political conception to conceptualize commercial law as a predominantly national, sovereignty-driven project.

281. See, e.g., Teubner, Global Bukowina, supra note 13, at 10; Tamanaha, supra note 24, at 42. Although Berman does not critique positivism, his is an important recent account that throws doubt on legal positivism as being able to offer an adequate descriptive account of globalized law. Berman, Global Legal Pluralism, supra note 24.

282. See supra notes 291-311 and accompanying text.

283. See infra notes 299-314 and accompanying text.

284. See supra note 24 and accompanying text.

285. As explained above, I adapt Nagel's distinction on approaches to understanding justice. See supra note 14 and accompanying text.

286. The norm-giver and norm-user terminology is from MACCORMICK, INSTITUTIONS OF LAW, supra note 33, at 20-22. 


\section{The Political Conception of Legal Positivism}

We can first easily dispense with any notion that force is the source of the authority of law. From the repudiation of force it is an easy step to repudiate command as the source of authority for a legal system. It is important to dispense with force or command as justification for a norm to be law because states have a monopoly on the permissible use of force and the declaration and enforcement of commands. In a transnational approach, non-state norm givers and norm users lack the means to force or command, nor do they have a moral right to use force to enforce their norms. No one takes seriously anymore the Austinian idea of law's authority coming from sovereign power and followed by subjects out of a habit of obedience of the sovereign. To Austin, the threat of sanction is what made law. In his words, "every law properly so called is set by a superior to an inferior or inferiors: it is set by a party armed with might, to a party or parties to whom that might can reach.,"287 Austin was the last of the prominent legal positivists to make explicit the need for a sovereign for a law to exist. The idea can be traced to Hobbes. A distinct break occurred between the "ancestral" positivists, Hobbes, to Bentham, ${ }^{288}$ and then on to Austin, who all endorsed the role of force in supporting law's authority, and "contemporary" positivists, who find law's authority in social practices, and ultimately even in custom. ${ }^{289}$ The delinking of positive law from force or command is a crucial step in finding positive law outside of the state.

What are the conditions analytical jurisprudence now requires for a legal system? It depends who you ask, but Hart's is certainly a canonical account. $^{290}$ We should also examine elements of Raz's account because he specifies uniqueness conditions for a legal system that effectively claim that a legal system cannot be anything other than a municipal legal system. I will attempt to summarize relevant parts of Hart and Raz in several paragraphs, which undoubtedly will do both their accounts disservice, but I want to identify the basic contours so we are clear on the obstacles before us.

Hart saw a legal system as a system of social rules, owing its existence entirely to human social practices, governing humans in societies. $^{291}$ Legal systems have what Neil MacCormick calls a

287. John Austin, The Province of Jurisprudence Determined (1995).

288. JeREMy BENTHAM, Of LAWS In GENERAL (H.L.A. Hart ed. 1970).

289. See Waldron, supra note 1 , at 93.

290. HART, THE CONCEPT OF LAW, supra note 8.

291. NeIL MACCoRmick, H.L.A. HART, supra note 11 ("The legal theory... presented [in the Concept of Law] is if a legal system of social rules, social in a double sense: both in that they govern the conduct of human beings in societies and in that they owe their origin and existence to human social practices.”). 
"systemic quality" because they are comprised of the union of primary rules of obligation and secondary rules of adjudication, change, and recognition. ${ }^{292}$ The systemic quality comes from the fact that primary and secondary rules relate to one another. Primary rules are rules that apply directly to human conduct, which specify crimes, torts, obligations, rights, duties, and so on. Secondary rules of adjudication give certain officials (the archetype is the judge) power to determine whether persons have violated primary rules. Included within rules of adjudication are rules of enforcement. Secondary rules of change are rules used to change primary rules. Examples of rules of change are the rules governing legislation. Rules of change include lower order power conferring rules that give persons that ability to change their legal relationships with one another, such as the power to contract, create trusts, and so on. Rules of recognition set forth the criteria for the validity of all other rules in the legal system. They are essential to the existence of the legal system because they tell officials and citizens which rules are valid in the legal system. For example, rules of recognition tell judges about the body of rules they can apply to decide a case. A legal system has to be "in force," which means that most persons subject to it obey primary rules most of the time. It does not matter why they obey. The officials themselves, however, must accept the rules of recognition from an internal point of view, which means that they have to accept them as binding on them and to take a critical view if another official fails to adhere to them. Social rules that are not legal rules might share content similar to legal rules. International law is an example. A minimum content of natural law is necessary for collective survival, and that minimum content is reflected in legal systems. Law and morality may overlap in content but lack a necessary connection. Gaps in the rules are filled by judicial discretion.

Hart did not say that his account only specified the conditions for a legal system. His claim seems to be that a legal system is an institutionalized normative system with the features he specified. A legal system of a state with a defined geographic territory could be seen as a central case for Hart. ${ }^{293}$ Raz accepts Hart's two-part description of law as the union of primary and social rules, and further specifies what makes a legal system unique. ${ }^{294}$ Raz's legal philosophy is much more than what is to follow, which covers only what is directly relevant to the task at hand.

292. Raz writes of “systemic validity.” RAz, PracticAl REASON AND NORMS, supra note 12 , at 127.

293. MACCORMICK, H.L.A. HART, supra note 11, at 33.

294. RAZ, PracticAl REASON AND NoRMs, supra note 12, at 126-27. 
Raz specifies three unique features of a legal system. First, legal systems are comprehensive. ${ }^{295}$ They claim authority to regulate any and all behavior within their jurisdictional competence. Other institutionalized normative systems, according to Raz, do not make this claim. Second, legal systems claim to be supreme, to regulate even other institutionalized normative systems. ${ }^{296}$ Despite the claim of supremacy, Raz concedes that two or more legal systems can co-exist in a single community, depending on their compatibility. Third, legal systems are open systems, which means that they contain norms the purpose of which is to supply authority to norms from outside of the system. ${ }^{297}$ Legal systems thus "maintain and support other forms of social grouping."298 They meet the open system requirement "by upholding and enforcing contracts, agreements, rules and customs of individuals and associations, and by enforcing through their rules on conflict of laws the laws of other countries, and so on." ${ }^{299}$ Raz further claims that legal systems are the most important institutionalized normative system to which people are subject. $^{300}$

In Raz's account of incorporation, or to use Raz's more general term, "adoption" is not of normative significance. Law sometimes supports other social arrangements. Raz specifies two tests, either of which a legal system must meet for adoption: (i) when the norms in force in another normative system are to be accepted by the legal system -an example is how conflict of laws rules recognize the laws of other countries; and (ii) when power-conferring rules in a legal system accept norms made by or with the consent of persons. The second test applies to "contracts, the regulation of commercial companies, and the like."301 In other words, the second test applies to the law merchant. Only if a norm meets either of these two tests can it be recognized in a legal system, but they do not become part of it. Raz advises that it would be imprecise to conceptualize legal systems around spheres of activity, but he does not say why. ${ }^{302}$ He also claims that we should not be concerned with rules for particular groups, unless the grouping is "normatively relevant. ${ }^{303}$

A final point that confirms Raz's political conception of legal positivism is his claim that the most important institution in an

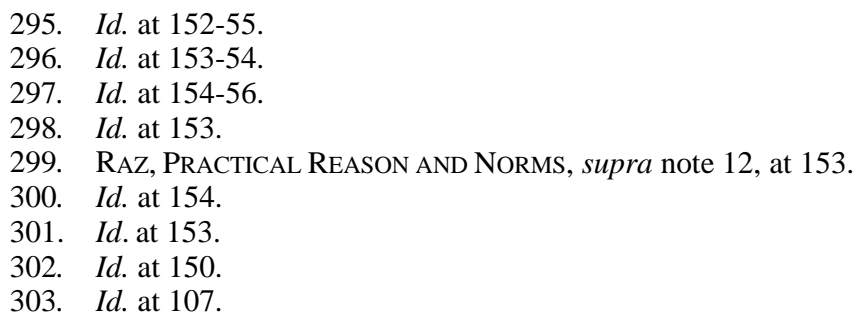


institutionalized normative system is "systematic and institutionalized" methods of norm-applying, in the form of norm-applying organs that have the power to determine the "normative situation" of persons, and issue binding "authoritative evaluations" or "authoritative applicative determinations," binding regardless of whether they are correct. ${ }^{304}$ These organs have "momentous importance" in any normative system. ${ }^{305}$ They resolve disputes, particularly in a system that has power-conferring rules recognizing voluntary obligations. They are a "defining characteristic of an important class of normative systems." ${ }^{\text {306 }}$ Raz argues that the rules of primary norm applying organs are "not a simple addition to a normative system. Their introduction radically transforms the system adding to it a whole new dimension, that of authoritative evaluation of behavior."307

In Raz's account of a legal system, rules permitting arbitration do not result in the production of norm applying organs. These rules are simply power conferring rules supporting social groupings. Arbitral institutions are not "primary" norm applying organs because they get their power through power conferring rules. ${ }^{308}$

Other legal positivists may disagree, but Raz provides a "conservative" account that gets as close as possible to specifying the requirement of a municipal legal system in all but name. In his book Practical Reason and Norms, published in 1990, Raz specified the above conditions for the law's uniqueness, but curiously, he provided a similar account in the Modern Law Review in 1975, which he included in his book, The Authority of Law, published in 1983, which explicitly limited his account of the uniqueness of law to a description of the features of a municipal legal system. ${ }^{309}$ Raz included no such limitation in Practical Reason and Norms. ${ }^{310}$

\section{The Concept of Commercial Law in the Political Conception}

The concept of commercial law in the political conception of legal positivism is well understood. In the political conception, commercial law is a discrete category of state law in a municipal legal system. We

304. RAZ, PRACTICAL REASON AND NORMS, supra note 12, at 134-37.

305. Id. at 137.

306. Id.

307. Id. at 142 .

308. Id. at 136 .

309. RAZ, ThE AUthority of LAW, supra note 43, at 103; Joseph Raz, The Institutional Nature of Law, 38 MoD. L. REV. (1975).

310. Brian Tamanaha has already shown Raz's restrictive conditions for a legal system to be problematic generally. TAMANAHA, supra note 24 at 139-42. I show below why Raz is wrong in the context of commercial law. 
can identify here the secondary rules associated with the primary rules identified in Part II.

The rules of recognition for municipal legislation are the rules that legislatures and executives use to enact legislation, usually rules associated with the passage of legislation by a legislature and signature by a chief executive, though these institutional details vary across countries. The rules of recognition for case law in legal systems that accept precedent are those relating to the practices of courts in producing and following precedent.

The rules of recognition for international conventions are easy to understand if one looks at the law from a state-based perspective. Governments use municipal rules of recognition to ratify or accede to a convention. ${ }^{311}$ Upon ratification or accession by the state's government, the convention becomes municipal law. Ratification or accession typically involves a state's executive in some form being involved with other state executives in the production of the convention text, and then state legislatures and executive departments act to ratify or accede to the convention so that it becomes valid legal rules in the municipal legal system. In American terminology, if the convention is not self executing, then ratification and accession binds the United States to the convention but the additional step of municipal implementing legislation is necessary to produce valid legal rules to be used in municipal courts by private parties. If the convention is, in American terminology, selfexecuting, then upon ratification or accession, the convention immediately becomes valid municipal law. In a political conception of positivism, no recognizing acts for these conventions exist to extend the legal validity of the convention beyond the state. There are no transnational acts of recognition for any legal system beyond the state. International law scholars postulate a customary rule of recognition such as pact sunt servanda to bind states to conventions, but not private persons. The state-based limitation is reflected in the fact that conventions are law only for states that ratify or accede to them, as Hart famously pointed out in chapter X of The Concept of Law. ${ }^{312}$

In the political conception of legal positivism, similar state-based limitations restrict a transnational conception of model laws. The rules of recognition for model laws are municipally based. They are the rules of legislative enactment of the model law. Without legislative enactment, model laws are simply persuasive theoretical authority on

311. Ratification and accession are commonly accepted terms in most municipal legal systems. I use them here to avoid unneeded abstraction. A more general term might be "acceptance."

312. HART, THE CONCEPT OF LAW, supra note 8, at 213-237. 
what good rules in the particular area should be. ${ }^{313}$ They have no practical authority over persons' actions. Model laws coming from UNCITRAL would be no different in terms of legal status than a UCC Article or uniform act that no state enacts.

In the political conception of legal positivism, the above categories of state-recognized law are the main sources of primary rules. In the political conception, the law merchant never becomes the law of the state. In the political conception, the law merchant is no more than contract terms. Incorporation does not convert non-state norms into state law. Incorporation is not an act of recognition. Rather, it is an act of adoption in Raz's terminology, a way the supreme but open legal system of the state supports other subordinate social groupings. Just as a state may support religious communities within its borders, so to it may support commercial communities.

Legal rules permitting citizens of the state to enter into legally significant arrangements even though they rely on non-state norms such as the law merchant are power-conferring rules. Power-conferring rules are rules of change, not rules of recognition. They are means by which the state confers power on citizens to alter relationships among themselves in the form of voluntary obligations. Power-conferring rules include contract formation rules, trust formation rules, and property transfer rules. That they are rules of change and not rules of recognition is normatively significant. They are not an act of recognition converting non-state law into state law. They are, rather, permission to deviate from default rules in the municipal legal system.

The reason states have power-conferring rules of change is that states often have an interest in supporting the private activities of their citizens. But municipal legal systems maintain claims of supremacy and comprehensiveness as well as openness, and limits are thus imposed on such private activities. These limits are seen in ways the state legal system asserts supremacy when necessary for reasons of public policy or ordre public. Public policy sometimes justifies overriding support for social groupings. Public policy reasons for rejecting rules that are not the state's rules are often found in legislation or in case law. ${ }^{314}$ Public policy reasons for refusing to support social groupings is a way for a state to assert that the state's interest must predominate, that the state's interest is too important to permit the social grouping to do something that fails to further that interest.

313. See supra note 10 on the difference between theoretical and practical authority.

314. See ALAN REDFERn \& MARTIN Hunter, LAW AND PRACTICE OF INTERNATIONAL COMMERCIAL ARBITRATION 96-98 (2004). 
In a political conception of legal positivism, the laws of other states are treated similarly to the law merchant but with important differences. If parties to commercial arrangements do not use power-conferring rules to choose the law merchant or foreign law to govern, then the relevant rules are supplied either by an international convention or by a conflict of laws analysis. In a political conception of legal positivism, conflict of laws analysis is important. And the law merchant has no place in that analysis. ${ }^{315}$ The only laws recognized in a conflict of laws analysis are the laws of other states. The reason why conflict approaches are seen as so strongly nationalistic and hence firmly within the political conception of legal positivism is because the animating principle underlying conflict of laws is the supremacy and comprehensiveness of state law. Conflict of laws is about selecting the law of a state when a commercial event crosses a political border and the law of more than one state arguably applies. $^{316}$ It is a competition between competing state orders. The logical conclusion of any conflicts approach is that all legal vacuums must be filled with state law. A contract or commercial transaction simply cannot exist without state law. A cosmopolitan conception of the law, as we shall see below, moves the questions of supremacy and comprehensiveness out and beyond the state. An approach that recognizes overarching norms valid beyond state borders presents conflicts lawyers with a fundamental contradiction.

Finally, in the political conception of legal positivism, normapplying organs, in Raz's words, "radically transform" a normative system. ${ }^{317}$ In Raz's account, Hart's rules of adjudication take on special significance. In a political conception of legal positivism, courts dominate the task of adjudication. Legal order simply cannot exist without institutions to provide authoritativeness in the form of evaluations of the conduct of persons subject to the law.

Moreover, the political conception facilitates a distinction between courts and "alternative" dispute resolution, ignoring the obvious fact that courts are alternative dispute resolution mechanisms in many commercial relationships that cross state borders. ${ }^{318}$ Arbitration is the

315. BERGER, supra note 146, at 78; Ralf Michaels, The Re-state-ment of Non-State Law: The State, Choice of Law, and the Challenge from Global Legal Pluralism, 51 WAYNE L. REV. 1209 (2005); Michaels \& Jansen, supra note 30.

316. See Frederick Juenger, Some Random Remarks from Overseas, in BERGER, THE PRACTICE OF TRANSNATIONAL LAW, supra note 30 at 81.

317. See supra note 307 and accompanying text.

318. I use the concept of alternative dispute resolution loosely here, as alternative dispute resolution specialists might not classify arbitration as alternative dispute resolution, since arbitration results in a legally enforceable award. GoODE, KRONKE, \& MCKENDRICK, supra note 116, at 627. 
preferred method of dispute resolution in commercial transactions that cross state borders.

Let's try to understand how to describe the role of courts and other norm-applying organs in the political conception when transactions cross state borders. In the political conception, arbitral panels conduct arbitrations within the territory of a state and are subject to the arbitration law of that state. Parties to the arbitration may seek assistance from municipal courts to enforce the arbitration agreement and the policies of the state on arbitration. This judicial action is generically referred to as supervision of arbitration by national courts. ${ }^{319}$ In the political conception, supervision is uncontroversial, indeed necessary. The idea of delocalization - the detachment of international arbitration from the law of the site where it is held-has no place, even if the parties so provide in their arbitration agreement. ${ }^{320}$ And the detachment of the arbitral award from the substantive law any state is impossible. ${ }^{321}$ Without state law no contract can exist between the parties, either for the underlying contract or for the arbitration. Arbitrators are bound to apply contractual choice of law provisions or conflict of law principles in making awards. Once the arbitrators issue an award, it may be recognized and enforced in any state that will recognize and enforce it. The 1958 New York Convention on the Recognition and Enforcement of Arbitral Awards, ratified by 137 states, facilitates recognition and enforcement by states. ${ }^{322}$ Convention Article $\mathrm{V}$ provides that states are not required to recognize and enforce arbitral awards in certain circumstances related to public policy. In the political conception of legal positivism, "public policy" means that the public interests of the state trump the private interests of the parties. Article $\mathrm{V}$ is an agreement between states on the form of permissible exceptions to recognition and enforcement. In these state-driven normative practices of supervision, recognition and enforcement, states claim their supremacy over the arbitral process.

319. See REDFERN \& HUNTER, supra note 314, at 13, quoted in id. at 628. Supervision is not the actual doctrine found in the law. The terms refers to several legal doctrines.

320. For an explanation of delocalization, see id. at 649-63.

321. Jan Paulsson, Declocalisation of International Commercial Arbitration: When and Why it Matters, 32 INT'L \& CoMP. L.Q. 53, at 54-57 (1983), quoted in GoODE, KRONKE, \& MCKENDRICK, supra note 116, at 659. Paulsson quotes the English arbitrator that has been influential in stating the case rejecting the notion of delocalization as well as the notion of a contemporary law merchant. F.A. Mann, Lex Facit Arbitrum, in INTERNATIONAL ARbitration: LibER AMiCORUM FOR MARTIN DOMKe (1967).

322. United Nations Convention on the Recognition and Enforcement of Foreign Arbitral Awards, June 10, 1958, available at http://www.uncitral.org/uncitral/en/ uncitral_texts/arbitration/NYConvention html (last visited Nov. 19, 2009). 


\section{B. Cosmopolitan Legal Positivism and Transnational Commercial Law}

This section puts the political conception under scrutiny. The account to follow suggests that the political conception of legal positivism is too restrictive and produces an incomplete and inaccurate description of a legal system. If positivism is truly independent of the existence of the state, then it should be able to describe a legal system independent of any requirement of a state. To be more precise, the question is whether a unified conception of a transnational legal system is possible. The political conception of legal positivism can already describe valid legal rules operating internationally but owing their validity to distinct municipal legal systems. We can see from the presence of important non-state rules, however, why such a description might be inadequate. As explained below, a positivist description that does not require a state is possible, but whether commercial law complies with that description is a separate question, the answer to which may be no.

\section{The Cosmopolitan Conception of Legal Positivism}

The cosmopolitan and political conceptions of legal positivism are in agreement that force or command is not the source of the practical authority of the law. Both approaches accept that a legal system can originate in what is essentially custom, or in Waldron's terminology, "custom like practices" ${ }^{323}$ in the form of secondary rules that the norm users of the given normative community accept. The rejection of force or command opens up the possibilities for revising positivism into a cosmopolitan account.

A cosmopolitan conception of legal positivism, one which removes the state as an enabling condition for a legal system, would require that five conditions be met: (1) acceptance by the participants in the legal system of the rules of the system as valid, binding, and authoritative; (2) systemic qualities of normative consequence within the putative legal system that make the normative order the system represents intelligible or comprehensible to the participants; (3) secondary rules and secondary rule officials, though they can be distributed across different state and non-state hierarchies; (4) shared agency between secondary rule officials demonstrating sufficient mutual responsiveness and joint commitment to a legal system; and (5) primary rules dealing with issues that legal systems usually deal with, such as property, contract, and dispute resolution. I will explain why each of these conditions is required for

323. Waldron, supra note 1 , at 93. 
any state-less legal system, or a legal system in which state rules are included but do not comprise the entire legal system.

As to the first condition, acceptance by the participants in the legal system of the rules of the system, this would seem not to be an important requirement in the political conception of legal positivism. The political conception places minor significance on the reasons why subjects in a community governed by common norms, which would be citizens of a state in the political conception, obey primary rules. Citizens of a state could have any number of reasons for obedience. What matters most for purposes of understanding the concept of a legal system deriving solely from the state is the internal reflective attitude of the officials who produce valid law. Though Hart and other legal positivists might deplore obedience based on habit as "sheeplike," 324 that persons have a number of reasons for obedience does not matter very much in the political conception. The hermeneutics of the political conception focuses on the norm givers, the officials who produce the rules and make them valid in the legal system. The beliefs and attitudes of norm users have more significance, however, when the normative community is not a state, because states maintain a longstanding arbitrary and involuntary association of persons who happen to find themselves within their political and geographical borders. In communities that are not formed by political borders, membership in the community is often voluntary and by design, if we accept some level of autonomy in life choices. For example, the reason why the UCP has practical authority to bankers is because bankers have accepted the UCP as law. Members of the banking community have an internal reflective attitude about the primary rules known as the UCP. It is not only the members of the ICC Banking Technique and Practice Commission that have a critical reflective attitude about secondary rules associated with the UCP. In a normative community that is not determined by state boundaries, the internal reflective attitude exists in both norm givers and norm users, towards both secondary and primary rules. In this sense, the concept of "in force" has a more stringent meaning than what one applies to a municipal legal system. ${ }^{325}$

Why is this so? Role or identity seems to be key in understanding the practical authority of rules in normative communities not formed by political borders. For example, if a person accepts a role or identity of a merchant, then the law merchant rules relevant to that merchant grouping apply to her.

324. HART, THE CONCEPT OF LAW, supra note 8, at 117.

325. Bhala, supra note 22, at 203-04 makes a similar point about the importance or acceptance of the law merchant by merchants, but his discussion differs from mine. 
What about the case where a merchant decides not to follow these rules? After all, they are default rules. The answer is that opting out is equivalent to a breach of the rules. It is a deviation from an established practice about which the norm users have a critical reflective attitude. Opting out of the rules will evoke a critical negative attitude from other merchants in the same grouping. For example, if a confirming bank on a letter of credit advises the issuing bank that it will not adhere to the UCP, that is essentially a breach of binding and authoritative rules that banks are supposed to follow. The idea of default rules has less relevance in such contexts.

As to the second condition, legal systems have systemic qualities of normative consequence that make them identifiable to both norm givers and norm users. Hart found these systemic qualities in the relationship between primary and secondary rules. Norm givers use secondary rules to identify valid legal rules for norm users. Norm users use rules of recognition to identify valid legal rules that norm givers create. Secondary rules of change work in a similar way. Secondary rules of adjudication give law-applying organs the authority to apply primary rules to resolve disputes for participants in the legal system. The bottom line is that in a legal system, secondary and primary rules relate to one another in a way that is readily identifiable to the participants in the legal system, and the participants have beliefs and attitudes about an identifiable legal system in which these primary and secondary rules operate.

States usually provide these systemic qualities. Other groupings do as well, but it is not just any grouping that counts. The grouping has to have normative consequences to the order being described. These systemic qualities give the system order and qualify it to be called a normative system. We need these systemic qualities for comprehension and identification of the normative order. We cannot understand a set of norms as a normative order without it. There has to be a reason for grouping the rules together as a legal system, such as in the need for a complete order regulating an area of importance to norm users.

As to the third condition, secondary rules and secondary rule officials may be distributed across different state and non-state hierarchies. The idea of a distributed environment comes from computer science, to refer to the spread of computer functions across different computers. The Internet is an example of a distributed normative environment, in which no comprehensive hierarchies claim supremacy over the entirety of the Internet, not even ICAAN. ${ }^{326}$ The Internet is

326. See generally Paul Schiff Berman, Towards a Cosmopolitan Vision of Conflict of Laws: Redefining Governmental Interests in a Global Era, 153 U. PA. L. REV. 1819 
governed not in a hierarchical structure of "top-down” formal authority, but through the coordinative actions of governments and private networks maintained by operators globally. No one entity regulates all of it. States are substantially involved in Internet governance, but so are non-state actors. I do not mean to suggest that the cosmopolitan conception of positivism or transnational commercial law neatly analogizes to Internet governance. The basic point here is that of distribution of functions in a decentralized way across various government and other hierarchically driven institutional structures, over a unified field of activity.

The cosmopolitan version of legal positivism acknowledges multiple rules of recognition, change, and adjudication in this distributed normative space. Even in a political conception of positivism, rules of recognition are multiple to reflect the fact that primary rules come with different content, form different categories of the law, come in different legal forms such as constitutional text and principle, legislation, and common law, and may reflect various levels of decentralization within a state or other community. For example, a local ordinance will be produced from rules of recognition differing from a constitutional principle. Matthew Adler supports his account of citizen groups as forming recognitional communities in U.S. constitutional law partly from Raz's claim that judges may have divergent rules of recognition yet still work within the same municipal legal system. ${ }^{327}$

As for the fourth condition, shared agency between secondary rule officials, law can be understood from the standpoint of planning. Some of the new thinking in analytical jurisprudence is in trying to understand the law as, in Scott Shapiro's phrase, "massively shared agency." 328 I can only introduce here the way the philosophical materials on plans and intentions could be employed to conceptualize a system of transnational commercial law. This approach might yield the most fruitful results in any future work on the concept of transnational commercial law. Legal philosophers have based most of their shared agency inquiry on the work of Michael Bratman. I do the same.

Suppose you and I are law students and we agree to form a study group with two other law students. Our aim is to produce an outline for

(2005); Paul Schiff Berman, The Globalization of Jurisdiction, 151 U. PA. L. REv. 312 (2002); David R. Johnson \& David Post, Law and Borders-The Rise of Law in Cyberspace, 48 Stan. L. Rev. 1367 (1996); David Post, Governing Cyberspace, 43 WAYNE L. REV. 155 (1996).

327. Adler, supra note 304, at 746.

328. Scott J. Shapiro, Legal Practice and Massively Shared Agency, available at http://www.law.yale.edu/yclp/papers/shapiro_paper.doc (last visited October 12, 2008). This work is based on MichaEl E. BRATMAn, FACES OF INTENTION: SELECTED EsSAys of INTENTION AND AGENCY 94 (1999). 
our Corporations course. It is an accurate description of the action of our group that we produced the outline. ${ }^{329}$ It would not be accurate to say that I produced the outline, and so did you and the other two students. We did it together. It is not a simple aggregation of parts of an outline. It cannot be, because we planned. There may be cases in which we do not plan ahead of time and simply share or aggregate parts of our own individual outlines, but that is a different situation. Shared agency accounts for the cases not involving only an aggregation of individual actions. An example of aggregation of individual agency is if all of us in the study group all happen to come from Los Angeles and we all individually decide to fly back to Los Angeles for the Thanksgiving holiday. It is true here to say that you are flying to Los Angeles, and I am flying to Los Angeles, and so are our two colleagues, but we are not flying together.

Bratman has argued that shared agency arises in two ways, either as a shared intentional activity or as a shared cooperative activity. A shared intentional activity meets the following two conditions:

(1) Mutual responsiveness: In SCA each participating agent attempts to be responsive to the intentions and actions of the other, knowing that the other is attempting to be similarly responsive. Each seeks to guide his behavior with an eye to the behavior of the other, knowing that the other seeks to do likewise. ${ }^{330}$

(2) Commitment to the joint activity: In SCA the participants each have an appropriate commitment (though perhaps for different reasons) to the joint activity, and their mutual responsiveness is in the pursuit of this commitment. ${ }^{331}$

So, we can all agree on how to divide up our outline coverage, with me taking fiduciary duty of care, you taking insider trading, and so on. These actions involve cooperation in the forms of mutual responsiveness and joint commitment, but an even stronger form of commitment exists in some forms of shared agency. To reflect the stronger form of cooperation, Bratman adds a third condition to describe the concept of a shared cooperative activity:

329. Shapiro, supra note 328 provides a good summary of Bratman's work.

330. Bratman cites to Chapter 4 of the classic game theoretic text of THOMAs C. SChelling, The STRATEgy OF Conflict (1960), in support of the first condition. BRATMAN, supra note 328, at 94-95. The citation to Schelling is revealing, in that the support for the first condition might be in a coordination game, in the nature of a Nash equilibrium.

331. BRATMAN, supra note 304, at 94-95. 
(3) Commitment to mutual support. In SCA each agent is committed to supporting the efforts of the other to play her role in the joint activity. If I believe that you need my help to find your note (or your paint brush) I am prepared to provide such help; and you are similarly prepared to support me in my role. These commitments to support each other put us in a position to perform the joint activity successfully even if we each need help in certain ways. ${ }^{332}$

In the law school outline example, if you are prepared to help me with my fiduciary duty material and I to help you with your insider trading material, our outline preparing is a shared cooperative activity.

Some who work within the political conception of legal positivism have argued that all or some of these conditions describe legal practices. They do not explicitly limit their accounts to municipal legal systems, but what they actually refer to are the practices of municipal legal systems. $^{333}$ A cosmopolitan conception of legal order can also employ Bratman's conditions to argue for a transnational legal order. The focus here is on the work of officials who make and apply the law.

Finally, the fifth condition, primary rules dealing with social problems that legal systems usually deal with, such as property, contract, and dispute resolution, is necessary to tell the difference between secondary rules in a legal system from those in other institutionalized normative systems. To my knowledge, no one has tried to answer that question. In his account of institutional normative order, MacCormick seems to assume that a municipal legal system is but one kind of institutional normative order but does not go beyond that conclusion. ${ }^{334}$ It just might be that looking for secondary rules unique to a legal system is the wrong way to go. The features of norm creation, application, and enforcement are common to our everyday language of normative practices and also of institutionalized systems we ordinarily do not think of as law. Churches, universities, sporting organizations, business entities, and civic clubs all have secondary rules of recognition, adjudication, and change. ${ }^{335}$ This is simply how life forms around institutionalized normative orders. Law makes no special claim on these features, just as it makes no claim to any special form of reasoning unique to it.

To conclude, we can describe a cosmopolitan version of legal positivism and find a legal system that does not require the state as an enabling condition if systemic qualities exist between primary rules and

332. Id.

333. Adler, supra note 304, at 729-45 summarizes this work.

334. See generally MACCORMICK InstiTUTIONS OF LAW, supra note 33; MACCORMICK, QUESTIONING SOVEREIGNTY, supra note 279, at 1.

335. See, e.g.,RAZ, Practical REASON AND Norms, supra note 12 at 150. 
secondary rules in groupings with normative consequences, in which the primary and secondary rules have practical authority, which means they are binding and authoritative on norm users and norm givers respectively, and which govern social problems that the law typically deals with. The secondary rules can be used by institutional actors within different hierarchies, with some coming from states and others not.

2. The Concept of Commercial Law in the Cosmopolitan Conception

Is there a commercial law order that meets the above five features of a legal system? Possibly so, but objections arise. I will go through each of the above five conditions for a transnational legal order and apply them to commercial norms.

As for the first condition, the above discussion elucidated the notion of the critical reflective attitude of the merchant or professional about commercial law rules not limited to source. In the political conception, the law merchant becomes reasons for action as law when incorporated into the state's legal system. In the political conception, merchants use state legal systems to give binding force to their social rules. Raz described incorporation as support by a legal system of social groupings other than those of the state. Incorporation can be accomplished legislatively, judicially, or contractually. By legislative incorporation I refer to legislation, like the UCC, supporting the notion that rules made by non-state actors, such as the law merchant, may apply to a given transaction. Legislative incorporation is simply a means to describe one way in which incorporation is accomplished. These same considerations apply to the other forms of incorporation, contractual and judicial. Courts may engage in a form of judicial incorporation, as we see in Harlow and Jones, ${ }^{336}$ BP Oil International, ${ }^{337}$ and St. Paul Guardian Insurance, ${ }^{338}$ although the latter two American cases may be seen as a form of "legislative" incorporation prompted by CISG Article 9. ${ }^{339}$ These courts hold that incorporation is required because of widespread merchant acceptance.

336. Harlow and Jones LTD. v. American Express Bank LTD., [1990] 2 Lloyd's L. Rep. 343.

337. BP Oil Int'l, Ltd. v. Empresa Estatal Petroleos de Ecuador, 332 F.3d 333 (5th Cir. 2003).

338. St. Paul Guardian Ins. Co. v. Neuromed Medical Sys. \& Support, 2002 WL 465312 (S.D.N.Y. Mar. 26, 2002).

339. CISG Article 9, available at http://www.cisg.law.pace.edu/cisg/text/treaty.html (last visited Oct. 10, 2008). 
The political conception fails to account for the way commercial actors, judges, and legislators understand the normative force of law merchant rules. In the cosmopolitan conception, the law merchant does not become reasons for action through incorporation into a state's legal system. The social rules of merchants do not acquire practical authority through and in the municipal legal system alone. Incorporation, or incorporation alone, is not what makes the law merchant valid legal rules in a cosmopolitan normative order. Rather, participants in the relevant normative community accept the law merchant before any contract is entered and regardless of whether any form of incorporation into a contract or municipal legal system has occurred. Acceptance in the relevant merchant community comes well before any incorporation. Incorporation is evidence of acceptance and authoritativeness. For example, the UCP acquires its authority because the ICC Commission on Banking Technique and Practice produces it. Banks are bound to the UCP not because it is incorporated, but because they accept it as law. To banks, the UCP is in many instances more important even than municipal banking law. The UCP is not accepted in this way as municipal law, but rather as transnational law unhinged from the state as an enabling condition for its existence.

The second condition, systemic qualities among primary and secondary rules, seems to have significant relevance to commercial law. Here we see what has become known as a governance gap, in which states do not regulate for whatever reason, either inability, unwillingness, or lack of interest to do so. ${ }^{340}$ State interests are determined by the political order in which they are situated, and commercial activity sometimes falls outside of this political order, or it is at least not apparent that it is the proper subject of the political order. Governments may not care about law relevant only to merchants who freely accept it, and which does not have the potential to harm non-merchant citizens. Moreover, it is sometimes the case that state-produced commercial law is inadequate without the law merchant. States claim a more significant or decisive role in regulating areas they have historically or traditionally deemed closely connected to their sovereignty or to the protection of their citizens. In other areas, non-state actors who represent the most cohesive and significant of normative communities tend to step into provide norms. For example, the UCP regulates a number of banking practices relating to documentary letters of credit. The UCP is authoritative on the strict compliance and independence principles in letter of credit law. States play an important role, however, in regulating

340. I borrow the "governance gap" terminology very loosely from the development studies literature. See, e.g., M.S. GogAn, THE GovernanCE GAP (2009). 
fraud on financial institutions and their customers in letters of credit. ${ }^{341}$ Here we see substantial coordination and mutual support. If we are to accept an American conception of commercial law, which includes consumer transactions, the role of the state becomes much more significant in consumer transactions, as the state and the political order it represents remains the primary source and justification for duties of justice, which have an important place in consumer transactions.

The same sort of systemic qualities of normative consequence among primary and secondary rules exist in transnational adjudication of commercial disputes. Unless state-run courts develop special expertise in areas of transnational commercial law, their main task is to recognize and enforce arbitral awards. Of course, for many wholly domestic commercial disputes, courts tend to be the primary rule-applying organs, but this may be changing as arbitration and alternative dispute resolution become preferred methods to avoid congested and under-funded courts that are too busy with criminal and other matters in which states have a substantial interest. At the transnational level, courts must be involved in enforcement because enforcement is about transferring assets to satisfy a decision by an authoritative person or body, usually by an arbitrator or arbitral panel. Asset identification and transfer is about property rights, and states maintain a dominant role in allocating these rights. But the authoritative evaluations themselves in commercial contexts-Raz's important norm applying organs - are often arbitral and not judicial in character. Each institution, judicial and arbitral, needs the other to perform coordinating and supporting functions.

Raz's political conception of legal positivism reaches the wrong conclusion from these examples. Raz claims that a legal system is open, that it supports other social groupings, but that it also claims supremacy over other social groups. He also says that legal systems claim to be a comprehensive normative order, which seems to contradict the openness condition. But Raz's claim fails for reasons other than this contradiction. Raz's legal positivism is an extreme version of the political conception. Its focus is almost entirely on the state's perspective. It is not that state support for other social groups is the relevant normative consequence associated with state acceptance of the law merchant. It is, rather, that the state needs the law merchant to support commercial law as a system. The supporting features of the relationship go both ways and reflect coordination between complementary normative domains and not support of a superior normative system for an inferior one. Legislated law merchant in particular supports state-based commercial law in areas in which the latter is deficient.

341. See John Dolan, The LaW of LetTers of Credit 55-56 (4th ed. 2007). 
The third condition, distributed secondary rules across different community hierarchies, deals with the work that secondary rules do and on the practices that effectively function as secondary rules. When we look at commercial law with the understanding of the functions of the secondary rules at hand, we find two related kinds of problems with the political conception of commercial law. First, the political conception offers an incomplete description of secondary rules that match up to primary rules. Second, the political conception offers an inaccurate description of the secondary rules of commercial law. Going through each of the main sets of primary rules makes these points.

It is true that municipal legislation requires the enactment of legislation by a state-based procedure. Those rules of recognition are included in the cosmopolitan version of legal positivism, but they are not the only rules of recognition, and some rules of recognition come from outside of formal state-run institutions. The state often does not work alone in creating valid legislation. Consider model laws and uniform acts. No legislature of any state, together or alone, can enact the UCC or its official revisions or any legislative product known as a uniform act or their official revision. Rather, the American Law Institute and the National Conference of Commissioners of Uniform State Laws must jointly agree on what is to receive their imprimatur through collaborative effort. $^{342}$ Several institutions jointly hold and apply the rules of recognition for uniform acts in the United States. It is an incomplete characterization of how rules of recognition actually operate to claim that uniform acts do not become law until enacted by a state legislature. To get an accurate description, we have to add the role of a non-state institution, the ALI, and a quasi-state institution, the NCCUSL. ${ }^{343}$ No uniform acts exist to ratify without their production by two non-state institutions. A similar analysis applies to model laws at the international level. No one can provide revisions of the UNCITRAL Model Law on Cross-Border Insolvency, for example, except UNCITRAL, an IGO.

So far, we have considered only state or state sponsored secondary rule officials. Going further, municipal legislatures depend on non-state actors to produce valid rules that they do not produce. States may forego legislation in a particular area because non-state actors fill the gap. For example, in the latest UCC Article 2 revision, the UCC drafters decided not to regulate delivery terms in sale of goods contracts, knowing that the ICC has produced superior terms in the form of INCOTERMS, and the preference of the drafters is for uniformity between transnational and

342. See Introduction-About NCCUSL, http://www nccusl.org/update/ (last visited May 27, 2009).

343. Id.; About ALI, http://www.ali.org/index.cfm (last visited May 27, 2009). 
national practices. ${ }^{344}$ It is not that the state accepts primary rules of other institutionalized normative systems to support the norm users in that other system. Rather, it is the combination of recognizing acts by state and non-state actors that bring transnational validity to these forms of the law merchant. That municipal law permits incorporation does not mean that municipal law maintains supremacy, but that it coordinates with merchant acceptance of rules in distributed normative space to support the transnational validation merchant rules through multiple acts of recognition.

A perhaps unusual practice is the use of FIDIC books as standard terms and conditions, often by developing country governments. Major construction almost always involves substantial sets of contract terms and conditions to fill gaps left by contract default rules. While FIDIC presents a troublesome example of the legislated law merchant because its substantial terms and conditions must be expressly agreed to as part of any construction contract, which makes them seem descriptively more like standard terms and conditions in a political conception, they must be understood also for their coordinating and supporting functions. States forego the production of their own valid rules for their own private and public contracts - their own standard contract terms and conditions-and instead rely of the production of valid rules by a non-state actor. It is true that FIDIC terms and conditions do not have normative force without contractual incorporation, but it is also true that they have no normative force without FIDIC promulgation. Multiple recognizing acts across different normative communities are required for FIDIC terms and conditions to be valid.

It is normatively significant that governments, particularly developing country governments, mandate the use of FIDIC terms and conditions in their public contracting. The development banks, in particular the World Bank and the regional development banks, mandate their use in their loans. ${ }^{345}$ They also require INCOTERMS. Here we see the distributed features of the secondary rules in action-governments,

344. UCC Sections 2-319 through 2-324 were "eliminated because they are inconsistent with modern commercial practices.” U.C.C. § 2-324 leg. note (2003). Delivery terms "must be interpreted in light of any applicable usage of trade and any course of performance or course of dealing between the parties.” U.C.C. § 2-319 leg. note (2003).

345. Development banks so mandate by making it a loan condition that the borrower use the bank's standard bidding documents in projects funded by the loan. The standard bidding documents require the use of FIDIC terms or conditions. Indeed, the terms and conditions usually are incorporated directly into the text of the documents. See World Bank Standard Bidding Documents Procurement of Works (May 2006, rev. March \& April 2007), http://web.worldbank.org/Wbsite/external/projects/procurement/ (last visited May 27, 2009). 
IGOs, and a non-state actor perform different acts of recognition. Each of these validating acts is necessary for FIDIC to be law in the transnational commercial law order.

Next consider international conventions. In the political conception, international conventions are creatures of state law. No international legal system exists to provide rules of recognition to validate their existence in that system. Rather, in the political conception, the rules of recognition serve to validate conventions for the municipal legal system. When we apply the cosmopolitan conception, we search for a set of mutually coordinating rules of recognition that validate conventions as transnational law. Though states have the power to negotiate conventions directly without the involvement of IGOs, this has not been state practice for commercial law conventions. Commercial law conventions almost always do not come into existence without substantial IGO involvement. They are produced by IGOs. Without IGO involvement there is nothing for a municipal government to ratify. The IGO's procedures are rules of recognition as well. As explained above, IGOs are government constituted, and so their actions may be seen as a delegation of state authority and thus supporting the political conception. But when we reconceptualize conventions in the cosmopolitan conception, we see conventions as part of the distributed normative space, in which IGOs, municipal governments, and merchant associations mutually support one another. The content of commercial law conventions coordinates just as municipal legislation does around the gaps left by the law merchant, and vice versa - the content of the law merchant coordinates around the two essentially state produced normative products of legislation and convention. Reflecting a high degree of coordination, the ICC has special consultative status with UNCITRAL. ${ }^{346}$

What to make of Honnold's "homeward trend" in the interpretation of commercial conventions? A political conception of legal positivism would reject autonomous interpretations of conventions while the cosmopolitan conception would accept them, and perhaps even require them. We can distinguish two cases. First, there will be cases in the zone of reasonable interpretation, in which judges in good faith fill gaps with competing reasonable but differing interpretations. These differences in the exercise of judicial discretion are inevitable. They do not defeat the cosmopolitan conception. But judges who refuse to apply a convention, as in Beijing Metals, or who refuse to examine the judicial decisions of other states when interpreting conventions, may be said to

346. Coordination of Work on International Trade Law, http://www.uncitral.org/ uncitral/en/tac/coordination html (last visited May 27, 2009). 
support the political conception as an adequate descriptive account. If officials are not committed to the cosmopolitan conception, then it will be a difficult case to make.

As for model laws mainly produced by UNCITRAL and UNIDROIT, these organizations provide a partial set of rules of recognition, but not enough to place the primary rules of these products "in force" in either the cosmopolitan or the political conception of legal positivism. They do, however, have persuasive authority and serve in an advisory capacity, and are thus more in the nature of theoretical authority. From these model laws we have reason to believe good law has the content these model laws have. ${ }^{347}$ A similar characterization applies to the UNIDROIT Principles of International Commercial Contracts, but since they are not legislative in nature, or at least not primarily so, ${ }^{348}$ they do not become law until they are in force as a result of frequent use by contract parties and arbitrators. The major difference the political versus the cosmopolitan conception makes for the UNIDROIT Principles is that the cosmopolitan conception accepts in principle that recognizing acts can occur outside of formal state enactment as law. Model Laws cannot claim such abilities. The UNIDROIT Principles are not law merchant unless commercial parties use them on a consistent and ongoing basis. They are in this sense like the UCP and INCOTERMS, but those clearly legislatively modeled products go through a formal and rigorous process of recognition by a normative community, which the UNIDROIT Principles do not.

Finally, within the discussion of the third condition, we should address secondary rules of adjudication. Raz has claimed that lawapplying institutions are "of momentous importance" and "radically transform" a normative system because they supply authoritative evaluations of actions by persons governed by the normative system. ${ }^{349}$ If this claim is meant to support the broader claim that legal systems are only state-based, it fails. It is in secondary rules of adjudication where we find that the cosmopolitan conception of a transnational commercial law makes its central case. With rules of adjudication we have a number of legal rules supporting a distributed normative space in which state and non-state actors coordinate and are mutually dependent on each other for authoritative evaluations. The cosmopolitan conception leads to a more

347. But see supra notes 112 and accompanying text (the political economy literature on "private" legislatures finds otherwise).

348. The drafters commend them as a possible model or guide for contract legislation. UNIDROIT Principles of International Commercial Contracts, Preamble ("They may serve as a model for national and international legislation.”), http://www.unidroit.org/ english/principles/contracts/main html (last visited May 27, 2009).

349. See supra notes 307 and accompanying text. 
neutral and descriptively accurate form of the Razian openness feature of a legal system when it comes to rules of adjudication. Here we see a horizontal and not a hierarchically based conception of how all of the parts of commercial dispute resolution cohere.

An example is the FIDIC norm applying organs. FIDIC specifies an extensive array of norm-applying organs to make authoritative evaluations of the conduct of parties to their contracts. In some of the more widely used books, the consulting engineer serves as the front-line norm applying organ, issuing authoritative evaluations that the parties to the contract are bound to follow, to continue work, and to pursue arbitration. $^{350}$ If the dispute makes it to an arbitral award, that arbitral award may be recognized and enforced in state courts under the New York Convention. ${ }^{351}$ With FIDIC we have a substantial set of rules of adjudication, with norm applying organs all the way down to routine contract operations.

In the political conception of legal positivism, states claim supremacy over international commercial arbitration. In the cosmopolitan conception, courts and arbitrators coordinate and are mutually supportive in a normative space that distributes over numerous state-based and other normative communities. Arbitral proceedings may be delocalized and detached from the law of the state in which the arbitral proceedings are being held if that is what the parties to the arbitration agreement intend. ${ }^{352}$ Parties to international commercial arbitration are almost invariably professionals or merchants, so state interests in consumer protection tend to be lessened. Since only states control territories, the arbitral site must necessarily be in a state, but geography or territory alone should have no normative consequences.

Ironically, though English lawyers tend to stridently support the political conception of legal positivism, ${ }^{353}$ their own courts provide an example of coordination and mutual support of rules of adjudication in the cosmopolitan conception. The United Kingdom has designated its Queens Bench Division of the High Court as the "Commercial Court." 354 The Commercial Court is partly intended to serve as a forum for the resolution of international commercial disputes, even where the parties to the dispute have no connection to the United Kingdom. The Court has

350. See supra notes 200-232 and accompanying text.

351. New York Convention on the Recognition and Enforcement of Foreign Arbitral Awards, http://www.uncitral.org/uncitral/en/uncitral_texts/arbitration/NYConvention html (last visited May 27, 2009).

352. See supra note 336 and accompanying text.

353. See, e.g., Mustill, supra note 19; Mann, supra note 172; Lord Kerr, Modern Trends in Commercial Law and Practice, 41 MoD. L. REV. 1 (1978).

354. HM Courts Service, http://www.hmcourts-service.gov.uk/infoabout/ admiralcomm/ (last visited May 27, 2009). 
existed for over 100 years. ${ }^{355}$ The Court's work focuses significantly on litigation relating to carriage of goods and charter parties, insurance and reinsurance, commodity transactions, and litigation of issues relating to arbitral proceedings. ${ }^{356}$ It essentially serves as an international tribunal for these matters. The Court and the profession generally have been accommodating to foreign parties. In Lord Denning's words in The Atlantic Star:

No one who comes to these courts asking for justice should come in vain. . . . This right to come here is not confined to Englishmen. It extends to any friendly foreigner. He can seek the aid of our courts if he desires to do so. You may call this "forum-shopping" if you please, but if the forum is England, it is a good place to shop in, both for the quality of the goods and the speed of service. ${ }^{357}$

On appeal, the House of Lords disavowed Lord Denning's dictum, ${ }^{358}$ but the dictum does reflect a tradition in English law. In Amin Rasheed v.Kuwait Insurance Corp., Lord Diplock noted that the Commercial Court was the preferred forum for nationals from a wide range of countries. ${ }^{359}$ An influential English conflict of laws treatise asserts that "there is a public interest in favour of trial in England in that when foreigners litigate in England, this forms a valuable invisible export and confirms judicial pride in the English legal system."360 In Miliangos $v$. George Frank (Textiles) Ltd., the House of Lords held that English courts could render judgments in money damages in foreign currency, in order to maintain the institutional advantages of English courts in resolving international disputes. ${ }^{361}$ As Lord Kerr explained in an article discussing the Miliangos case:

Foreigners have confidence in our legal system. But they no longer have confidence in sterling. They can now continue to contract in stabler currencies, but continue to come here for the resolution of

355. GOODE, COMMERCIAL LAW, supra note 89, at 1170.

356. Id.

357. The Atlantic Star, [1973] 1 Q.B. 364, 381-82, quoted in Friedrich K. Juenger, Forum Shopping, Domestic and International, 63 TUL. L. REV. 553, 565 (1989).

358. The Atlantic Star, [1974] A.C. 436, 454 (per Lord Reid).

359. Amin Rasheed v.Kuwait Insurance Corp., [1984] A.C. 50.

360. James Fawcett \& Janeen M. Carruthers, Cheshire, North \& FaWCEtT PRIVATE INTERNATIONAL LAW 440 (14th ed. 2008) (citation omitted); see also J.J. Fawcett, Forum Shopping: Some Questions Answered, 35 NR. IR. LEGAL Q. 141, 146 (1984), cited in Juenger, supra note 357, at 565-66.

361. 1976 A.C. 443. 
disputes, without the danger of having to accept payment in sterling at a devalued rate. ${ }^{362}$

These policies are cosmopolitan. They serve to maximize choice for parties in dispute resolution, who may choose either the Commercial Court or arbitration. They support the notion that multiple rules of adjudication operate in a distributed fashion across multiple normative communities to promote a transnational commercial legal order.

As for the fourth condition, shared agency among secondary rule officials, a transnational commercial legal order is plausibly a shared intentional activity. Mutual responsiveness and joint commitment seem to exist with groups of officials who operate both within and outside of states. Those officials are municipal legislators, municipal judges, IGO representatives and IGO bureaucratic personnel, non-state institutions and their officials involved in the making of the legislated law merchant, international commercial arbitrators, and non-state institutions involved in managing international commercial arbitration. These officials who have the task of using secondary rules, though they are in different normative communities, do seem to be engaged in a shared intentional activity, at least when a commercial matter crosses a state border. They are mutually responsive and engage joint commitment. We at least have shared intentional activity. They respond to each other's actions, either in law making or in adjudication. As we have seen above, they regulate normative spaces in a complementary way. Also, these state and nonstate actors exhibit a joint commitment to regulating commercial activity, but for different reasons, and those reasons do not defeat the fact of joint commitment. They have different reasons to support the transnational commercial law order because they work for different principals. State officials work for citizens of the state. Business association representatives work for industry. IGO officials work for the community of states. But their commitment to the transnational normative order is joint.

A transnational commercial legal order is unlikely a shared cooperative activity. It is doubtful that secondary rule officials working in different normative communities support each other's activities in the strong sense of helping each other do their jobs. An argument can be made that an arbitral panel, for example, might avoid certain rulings on antitrust law so that the arbitral award will be enforced. As another example, FIDIC might avoid regulating workplace safety so as to give the state an opportunity to do so. These actions or inactions are not mutual support. One norm applier or norm giver is simply avoiding

362. Quoted in Lord Kerr, Modern Trends in Commercial Law and Practice, 41 MoD. L. REV. 1, 10 (1978) and Forte, supra note 64, at 59. 
conflict and their complementary positions coincide or coordinate, but they do not cooperate in the strong form of cooperation that the SCA condition requires. There is no mutual support. FIDIC is not helping a state regulate workplace safety. The arbitrators are not helping the state restrict anti-competitive practices.

That it is unlikely that a transnational commercial legal order is a shared cooperative activity does not mean that it is not a legal order. Even municipal legal orders are unlikely to be shared cooperative activities. $^{363}$ A shared cooperative activity is unnecessary to finding a legal order. It would be, at best, nice to have that condition fulfilled, but the necessity condition is some lesser form of shared agency, perhaps a shared intentional activity. What actually is necessary in a legal system is a large question which is the subject of ongoing debate, and whose resolution is beyond our scope here. ${ }^{364}$

The fifth condition, the presence of primary rules regulating social problems that legal systems usually regulate, is easily met in the description of the transnational commercial law order. The rules in question have mainly to do with contract, property, and dispute resolution.

\section{Objections}

A number of objections may be raised against the cosmopolitan conception and against my use of it to attempt to conceptualize a transnational system of commercial law. I identify and address two: (a) the incompleteness or limited domain objection, that specifying a legal order around one legal category-commercial law-is untenable; and (b) the unity objection, arguing that it seems more plausible to claim that transnational commercial law is comprised of rules of distinct and multiple normative communities, which are interdependent and which coordinate, but to claim that they form a unified legal system may go too far.

\section{a. The Limited Domain Objection}

Law, like other social rules, is group relative. ${ }^{365}$ For example, social norms governing manner of dress, eating and sexual behavior are group relative, that is, they vary with groups and over time. ${ }^{366}$ Law does not address many aspects of life. Moral philosophers spend most of their

363. Shapiro, supra note 328.

364. Adler, supra note 304, at 750-64 discusses the literature.

365. Id.

366. Adler, supra note 304. 
effort understanding a normative sphere outside of the law. Morality does not threaten law's existence. Group relativity is not a feature of a rule that makes it something other than law. It is not a necessary condition for law's validity that it not be group relative. In fact many norms that no one would disagree are official state law are group relative. Constitutional law on freedom of religion applies only to people who practice religion. Commercial law applicable to merchants applies only to merchants. ${ }^{367}$ UCC Article 2 applies only to the sale of goods.

Law certainly is group relative, but we cannot describe a legal system around one of the groups identified by such group relativity. We might not be able to describe a transnational legal system around commercial law alone. Law is not comprehensive in the Razian sense, in that law does not purport to regulate (or be able to regulate) all aspects of our lives, but it does not purport to cover a single field or limited fields of human action. How can we have a legal system that addresses only one area of life, commerce?

There are two replies to the limited domain objection. First, it might be possible to describe a legal system around a group in which such a description has the right sort of normative consequences. The systemic unity and shared intentionality features of the transnational commercial law order suggest a relationship between commercial law norms to justify the classification as a legal system. Some groups are not normatively relevant. For example, it would be implausible to describe a legal system around all left handed people because the feature of lefthandedness has no or perhaps insufficient normative importance. Some groupings would indeed be repugnant, such as groupings in separate apartheid-like legal systems for different citizens of a state. But that some groups are not normatively relevant or normatively repugnant does not condemn all groups from being able to form legal systems around the pervasive and important social practices that regulate their action beyond state borders.

The second reply is that commercial law itself may be incomplete as a concept without a transnational conception. This reply runs the risk of being circular. The point here is only that when we examine how

367. Harold J. Burman \& Felix J. Dresser, The "New" Law Merchant and the "Old": Sources, Content, and Legitimacy, in CARBOnneAu, supra note 57, at 53 (The law merchant is not a complete legal system; it was never meant to be, even in medieval times); Andreas F. Lowenfeld, Lex Mercatoria: An Arbitrator's View, in CARBOnNEAU, supra note 238, at 71 (The law merchant "supplies the solution to a particular issue, without necessarily governing all aspects of the transaction." The law merchant is an alternative to conflict of laws analysis, which is often "artificial and inconclusive," and a way out of applying rules ill-suited to international transactions.); BERGER, CREEPING CoDificAtion, supra note 146 at 93 (law merchant not a "self contained" system, but domestic commercial law is incomplete). 
commercial law operates in the world, we need an account to capture its essential cosmopolitan features.

\section{b. The Unity Objection}

The unity objection might seem difficult to overcome. It is actually, however, just an old "law is politics" claim. A way to dissolve the unity objection might be to try to remove politics from the analysis. Is there something unique about a legal system apart from its place in a political order? Scholars of analytical jurisprudence have been asking similar sorts of questions for a long time. When we get precise about our claims and remove from the discussion the political allegiances that lawyers, legislators, and judges might naturally associate with their municipal legal system, we can attempt a description of a transnational legal order in which the unity objection becomes a political fact with some, but not decisive or fatal, force over the legal order we purport to describe.

\section{CONCLUSION}

In this article I have tried to use conceptual analysis to articulate a cosmopolitan conception of legal positivism and to develop it into a concept of commercial law as a transnational normative order. This article is only a start of such an account and no doubt it will benefit from scrutiny and counterargument. And the account of a stateless or cosmopolitan conception of legal positivism has relevance beyond commercial law.

This article offers no prescriptions. It does not ask whether a transnational commercial legal order is just. Analytical jurisprudence is a search for the existence conditions for a legal system and the validity conditions for legal rules. It is not about the evaluation of a legal system using principles of justice or other substantive moral values. The focus is on what is a legal system not what is a just legal system. ${ }^{368}$ These are important limitations. This article offers no evaluation of the content of the principles of justice that may or may not be reflected in the law merchant or the transnational commercial law order. It might just help us expose the considerable concerns we might have when consumers transact in a normative order in which the state has limited power to protect them. Concerns about the justice of such an order resonate across a diverse assemblage of scholars working in divergent traditions. The first quote by Hal Scott to start off the article was from an article about

368. For an explanation of the differences in the analysis, see RAz, PRACTICAL REASON AND NoRMS, supra note 12, at 10-13. 
how banks use the law merchant to shift risk to customers. ${ }^{369}$ Thomas Carbonneau and François Janson, who write on international commercial arbitration, explain:

Law will be generated within the confines of a fully privatized system that is unaccountable to any public organization or process. Arbitrators, lawyers, arbitral institutions and law firms will become the de facto government and the courts of international trade and commerce. $^{370}$

Seyla Benhabib explains:

To be distinguished from the influence of cosmopolitan human rights norms is the undermining of state sovereignty through the demands of global capitalism. Global capitalism is indeed creating its own form of "global law without a state" (Gunther Teubner), as well as sabotaging the efforts of legislators to conduct open and public deliberations on legislation impacting the movements of capital and other resources. ... My thesis is that whereas cosmopolitan norms lead to the emergence of generalizable human interests and the articulation of public standards of norm justification, global capitalism leads to the privatization and segmentation of interest communities and the weakening of standards of public justification through the rise of private logics of norm generation. This results in the deterioration of the capacity of states to protect and provide for their citizens. ${ }^{371}$

Law and economics scholars like Bruce Benson argue to the contrary, because, they claim, governments do not make good commercial law because of rent seeking and other pathologies of the political process. ${ }^{372}$ But the focus of law and economics scholars is on efficiency, not justice.

Questions of justice are beyond our scope here. But once we get clear on what is going on, we can more effectively focus on questions of justice because we have improved our understanding of the norms that we want to investigate. The normative order I have tried to identify in this article certainly should be subjected to normative evaluation.

369. Scott, supra note 2 .

370. Thomas E. Carbonneau \& François Janson, Cartesian Logic and Frontier Politics: French and American Concepts of Arbitrability, 2 TuL. J. INT'L \& CoMP. L. 193, 221-22 (1994), quoted in Christopher R. Drahozal, Contracting Out of National Law: An Empirical Look at the New Law Merchant, 80 NotRE DAME L. REV. 523, 525 (2005).

371. Seyla Benhabib, Twilight of Sovereignty or the Emergence of Cosmopolitan Norms? Rethinking Citizenship in Volatile Times, CiTIZENSHIP STUDIES, Feb. 2007, at 19-36 (emphasis in original) (citations omitted).

372. Bruce L. Benson, The Spontaneous Evolution of Commercial Law, 55 S. ECON. J. 644, 644 (1989). See also supra note 110 for the political economy literature on unification, supporting Benson's argument. 
One question that seems to follow from this article is whether we can have a cosmopolitan account of the law and a political account of justice. It might just be that states are the primary spaces for justice. Thomas Nagel certainly has it right when he says that "the need for workable ideas about the global or international case [for justice] presents political theory with its most important current task. . . .”373 While this article fills one gap in the literature, others remain open, and one that certainly needs critical attention is the critique, from the standpoint of justice, of any transnational commercial law order we may find.

373. Nagel, supra note 14 , at 113. 